

\section{DEMOCRACY IN ACTION}

Annual Outcome Report 2019

Graphic design: Vision Communication

ISBN: 978-91-7671-304-4

DOI: https://doi.org/10.31752/idea.2020.12 
Annual Outcome Report 2019

\section{Contents}

Reclaiming democracy's promise.

Letter from the Secretary-General.

Introduction

Assessing global democratic progress

The Global State of Democracy Indices-an important source for EU decision-making ............................6

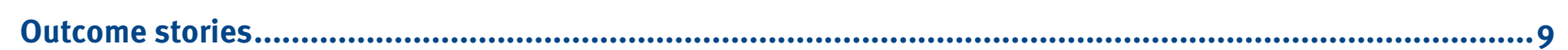

Supporting excellence in elections: the cases of Nepal and Timor-Leste ..................................................10

Trailblazing electoral risk management........................................................................................12

Working to enhance electoral regional cooperation in Melanesia ..........................................................14

Building a cyber-resilience mindset .............................................................................................16

Dutch state commission uses International IDEA recommendations on digital microtargeting ..............18

Increasing Myanmar election staff's understanding of rules and regulations will be key for a

successful 2020 election ........................................................................................................................20

Forging a state and civil society partnership on electoral processes in Fiji

....22

Improving mechanisms to enhance electoral regulatory frameworks in the Southern African

Development Community .................................................................................................................24

Establishing the Arab Network for Women in Elections .........................................................................26

Mexico: International IDEA renews commitment to promote access to electoral justice ........................28

Supporting Bangsamoro Autonomous Region in Muslim Mindanao at a critical juncture........................30

Constitutional Review Commission of The Gambia leads constitutional review process with

International IDEA assistance ................................................................................................................32

International IDEA supports constitution makers in Myanmar's Union Parliament .................................34

Yemen: Inclusive dialogues for peace...........................................................................................36

Supporting the federalization process in South Sudan ..................................................................38

Working on constitutional reform in Lebanon ...................................................................................40
Mentoring elected local officials in Nepal ...................................................................................42

International IDEA looks to regional governance in Bolivia to bolster development................................44

Training for increased women's political participation in Myanmar ......................................................46

Promoting the responsible use of social networks and regulating political financing in Argentina .....48

Strengthening women's political participation in Bhutan ...............................................................50

Developing a Code of Conduct for elections in Moldova ...................................................................52

Supporting women candidates for parliamentary elections in Tunisia ..................................................54

CANDI Dat@s: a stake on informed voting........................................................................56

Ukraine: Party innovation hubs help spark political interest among young activists ..............................58

Breaking down gender barriers in Paraguay ........................................................................................60

Fostering collaboration and citizen observation in Mozambique .........................................................64

Women leaders translate rights into outcomes in Central African Republic.............................................66

Promoting cooperation between political parties in Ethiopia .....................................68

A community's transition from 'no man's land' to an inclusive cultural space in Peru.............................70

The Inter-Regional Dialogue on Democracy offers regional and global connections to achieve

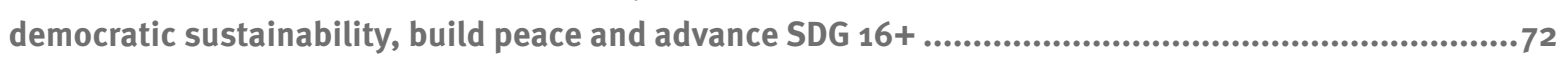

Advocating for stronger democracies: International IDEA and the European Union .........................................74

Helping to shape democratic governance at the European Union level ......................................................74

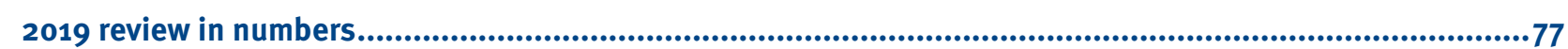

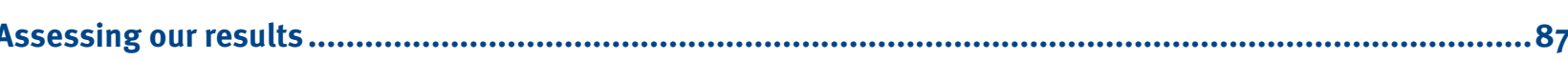

Results framework ...........................................................................................................................8

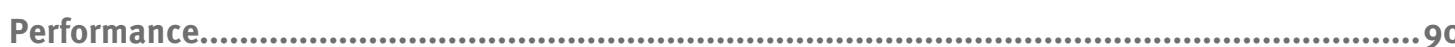

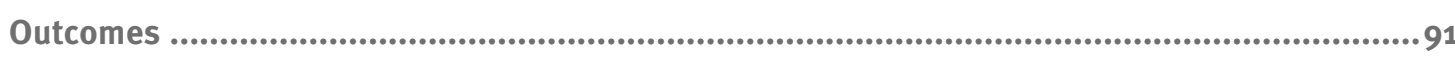

Impact ................................................................................................................93 
Letter from the

\section{Secretary-General}

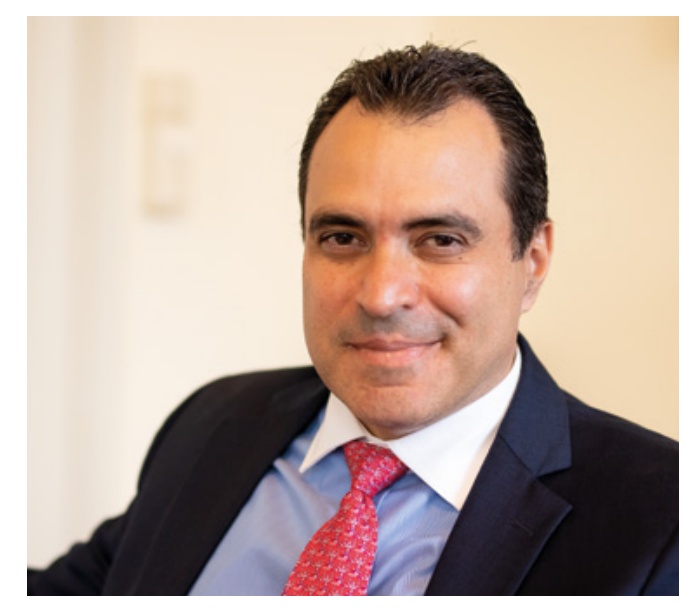

Democracy is experiencing severe challenges all over the world. Democratic backsliding, authoritarian leaders, infringements of the rule of law, persistent corruption and inequalities make daily news headlines. Despite democracy's current ills, there are also signs of hope and progress that should be acknowledged and celebrated.

The Global State of Democracy 2019: Addressing the Ills, Reviving the Promise, launched in 2019, provides a global democracy diagnosis that is both worrying and hopeful. Our data, covering 158 countries, demonstrates that democracy continues to expand its global reach, while its quality also deteriorates across the board.

The Global State of Democracy Report and the Timing and Sequencing of Transitional Elections, a policy pape based on 15 case studies of transitional elections from around the world, are only two examples of our vocation to produce policy-oriented and research-based publications. Our analysis and data can help multilateral and international organizations identify priority areas for reform and priority countries for support. Furthermore, the knowledge is designed to provide practical support and tools to actors working on democratic reform processes at the sub-national, national and regional levels.

Our ability to develop high-quality, evidence-based knowledge products and link them to reform processes on the ground has always been part of International IDEA's dual nature of a 'think-and-do-tank'.

We think, because for 25 years we have been producing comparative knowledge on electoral systems, political reform, constitutional design, political finance, gender equality in politics, and democratic governance, to name few. We do, because we apply that knowledge and expertise through technical assistance on the ground.

In 2019, we expanded our global reach by stepping up our efforts to increase the effective functioning of parliaments through the European Union (EU)-funded Inter Pares-Parliaments in Partnership project and the Join Public Accounts Committee project in Myanmar, funded by the EU and the UK's Department for Internationa Development. We have worked to support political reform processes in countries undergoing recent democratic transitions, such as Ethiopia, The Gambia, Malaysia, Myanmar, South Sudan and Sudan.

International IDEA embodies the notion that the struggle to advance democracy should not be a solitary endeavour. There is value in systematizing and facilitating comparative knowledge and experience about democratic processes to those that are in the trenches building democracy.

In 2019, we welcomed Tunisia as our 33rd Member State, and continued to increase our engagements with existing Member States, partner organizations and civil society representatives.
Looking ahead, in 2020 International IDEA commemorates 25 years since its establishment. We will use the anniversary year to craft a forward-looking agenda for the Institute. As we commence the Decade of Action to Achieve Agenda 2030, International IDEA strives to contribute to a world that is more fair, peaceful and democratic for all.

\section{Dr Kevin Casas-Zamora}

Secretary-General
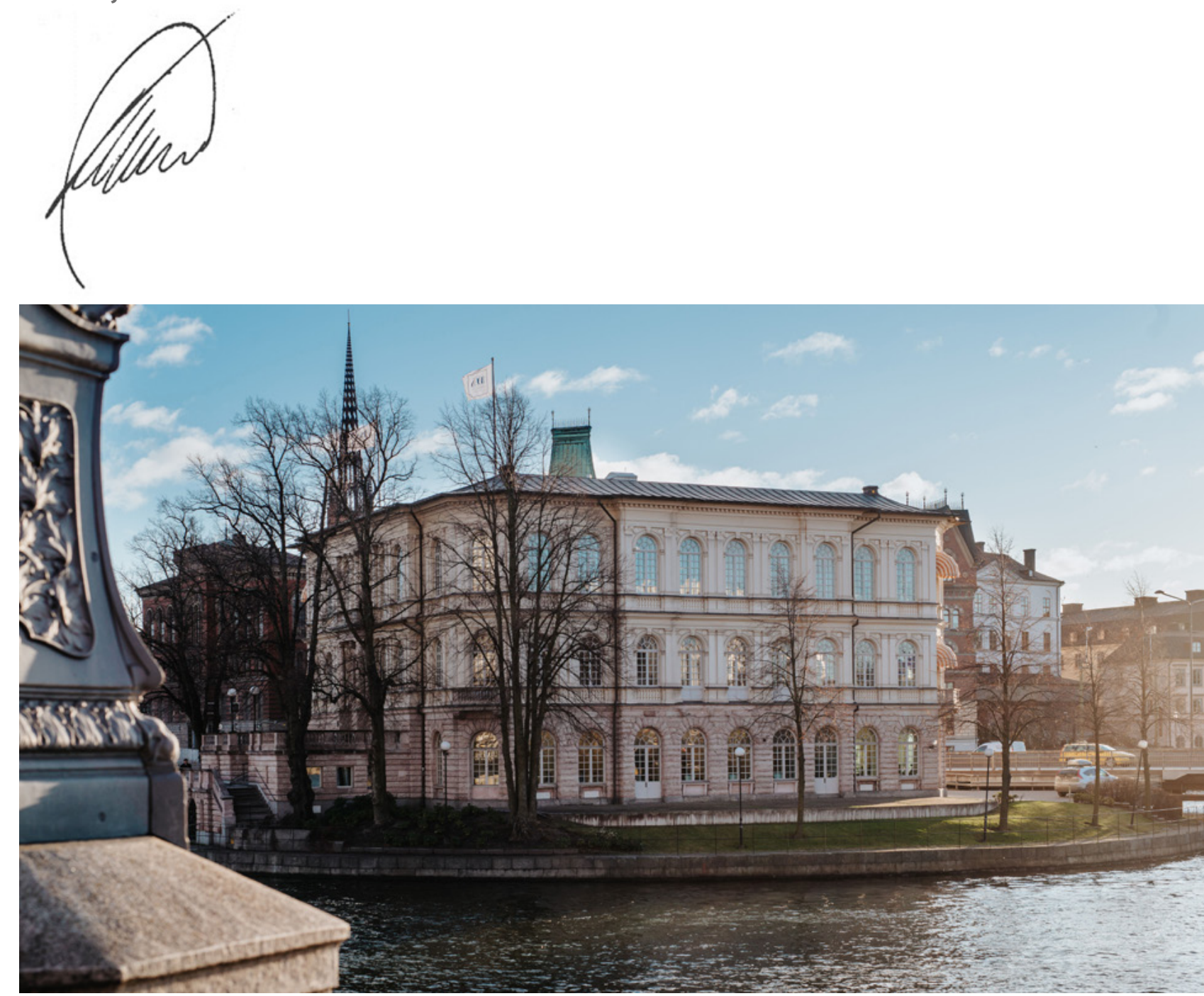

International IDEA headquarters on Strömsborg in Stockholm, Sweden. 


\section{Introduction}

At International IDEA, we advance democracy worldwide, as a universal human aspiration and an enabler of sustainable development, through support to the building, strengthening and safeguarding of democratic political institutions and processes at all levels.

\section{Our approach}

We believe that democracy is a universal human aspiration and an experience that is pursued and lived in different ways around the world. It comes in multiple forms. These forms are in constant evolution. There is no single and universally applicable model of democracy. There is no end point in improving democracy.

Fundamentally, democracy is a system in which the government is controlled by the people and citizens are considered equals in the exercise of that control. Beyond the basic tenets of citizens' choice and citizens' political equality, the critical choices are best made and the quality of democracy is best gauged by those directly concerned: the citizens themselves. We systematically nurture an open and pluralistic understanding of democracy. This is respectful of the national context, and is in line with our non-prescriptive and non-intrusive approach, as well as with the priorities set by national actors.

Learn the latest information about our activities, our Member States, Board of Advisers and Secretariat, as well as how you can get involving in supporting democracy worldwide.

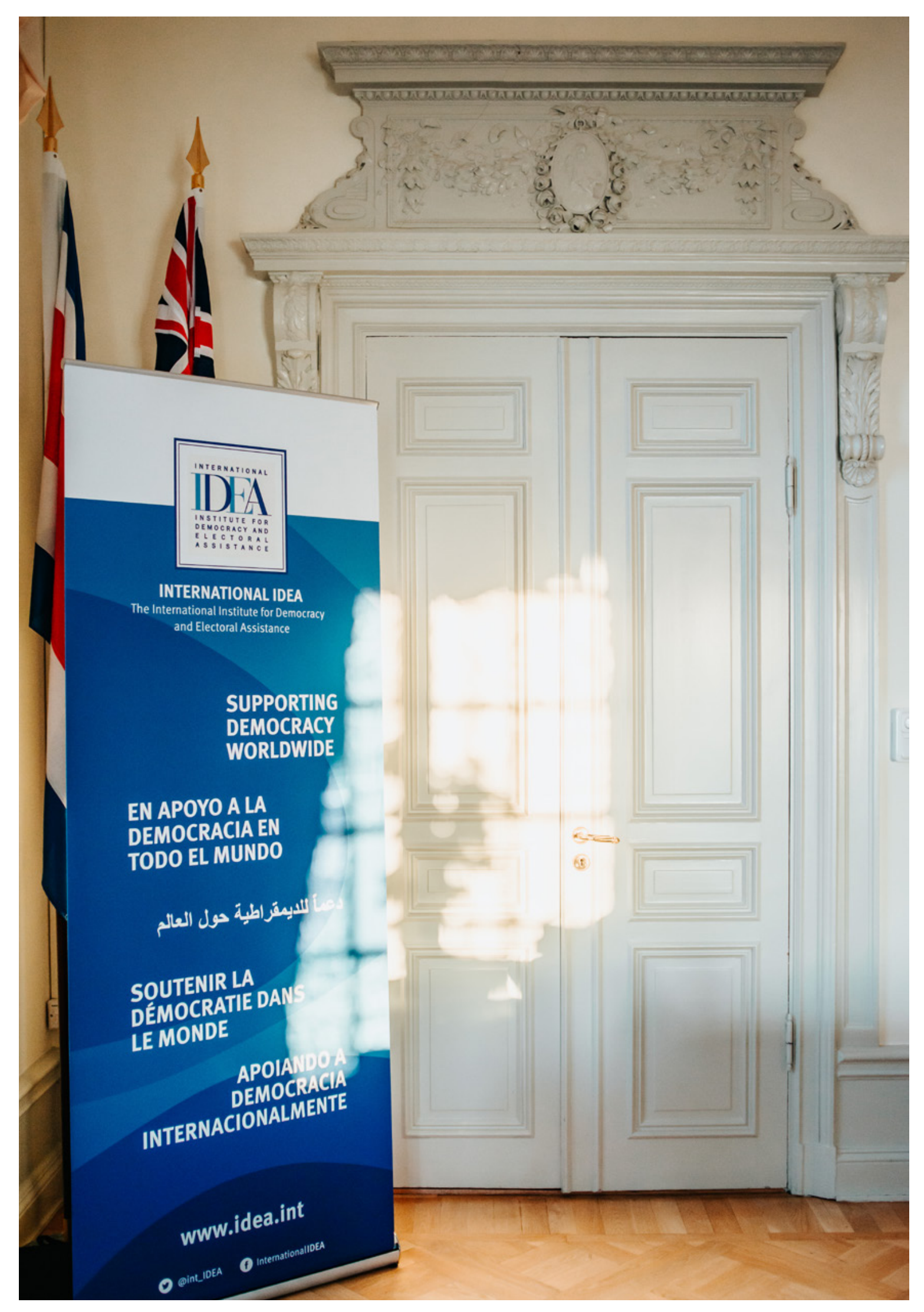




\section{The Global State of Democracy: an International IDEA Initiative}

The Global State of Democracy (GSoD) Initiative, launched in 2017, provides evidence-based analysis and data on the global and regional state of democracy to contribute to the public debate on democracy, inform policy interventions and identify problem-solving approaches to trends affecting the quality of democracy. The initiative provides up-to-date indices as a digital tool, a biennial publication and regular evidence-based analysis briefs called GSoD In Focus.

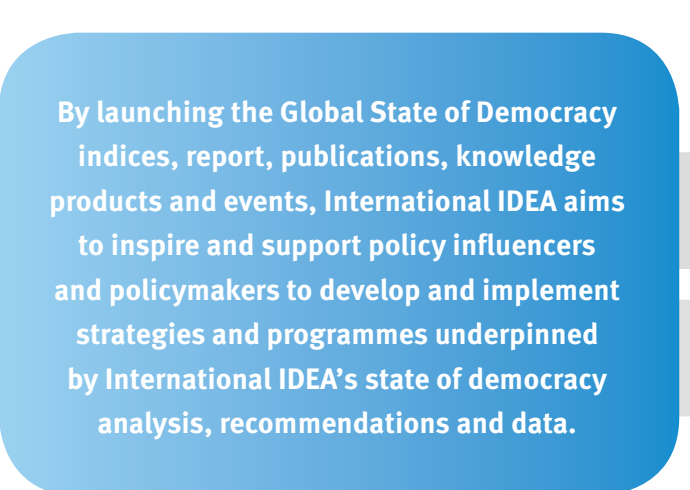

Boundary partners: International, regional and national
policymakers, policy influencers and civil society organization

Funding

\section{Core}

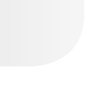

For example, Sweden's Ministry of Foreign Affairs has adopted a democracy framework that is modelled on the GSoD framework in its 'Drive for Democracy'. Last year, its government agency for development, Sida, included GSoD as one of the main sources for democracy analysis which underpins democracy support programmes. In a note to staff, the agency wrote, "The advantage of $\mathrm{GSoD}$ is the breakdown of the concept of democracy in a large number of indicator and the long time series that enable comparisons over a long period of time.

The report has also received high-level endorsements from the European Union's (EU) High Representative for Foreign Affairs and Security Policy, Mr Josep Borrell. Media outlets have cited the report in articles in over 16 countries in Africa, Europe, Latin America and the Middle East.

High Representative of the European Union for

Democracy "health check' gets global thumbs up

\section{The Global State} of Democracy 2019

In 2019, International IDEA published the second edition of its annual report assessing the state of democracy in the world, which seeks to shift the global debate surrounding the issue. The flagship publication, The Global State of Democracy 2019: Addressing the Ills, Reviving the Promise, analyses democratic performance across 158 countries from 1975 to today. It provides a health check for democracy by analysing the trends, opportunities and challenges it faces. Over 150 participants attended the report's global launch in Brussels on 19 November. Additional global launches were held in Stockholm and New York, followed by regiona launches in Addis Ababa, Bali, Brussels, Mexico City and Tunis. The GSoD Initiative has given stakeholders including policymakers and civil society a chance to reframe their discussion of democracy from one of 'doom and gloom' to ways to revive and strengthen its delivery. oreign Affairs and Security Policy, Mr Josep Borrell, tweeted after giving delivering the keynote speech at the global launch:

The Swedish Ministry for Foreign Affairs also

Josep Borrell Fontelles @JosepBorrellF. 19 de nov. de 2019 by on information and now that we are surrounded by fake news, it is a good

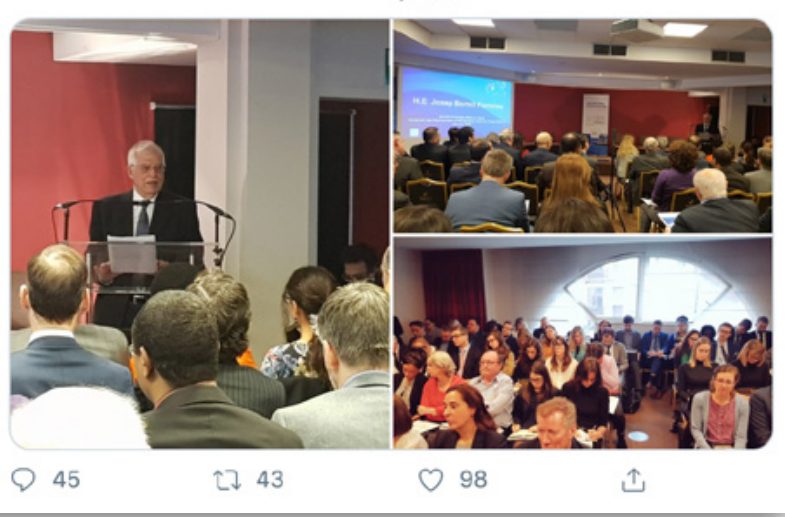

tweeted the day of the launch
Swedish MFA @SWeMFA . 19 de nov, de 2019 Sweden is proud to be a member and supporter of International IDEA, as
they yaunch the Global State of Democracy 2019 report today. Sweden -
A strong voice for a \#DriveForDemocracy (2) International IDEA @int_IDEA. 19 de nov. de 2019 IfI T The Global State of Democracy 2019: Addressing the IIIs, Revind out how till is democracry and what are the remedies FReviveDemocracy \#CSOOD2019 \#Stateoffe tomocracy

1 


\section{The Global State of Democracy Indices- an important source for EU decision-making}

International IDEA's data and analysis informs the Council of the European Union's programming in the field of democracy

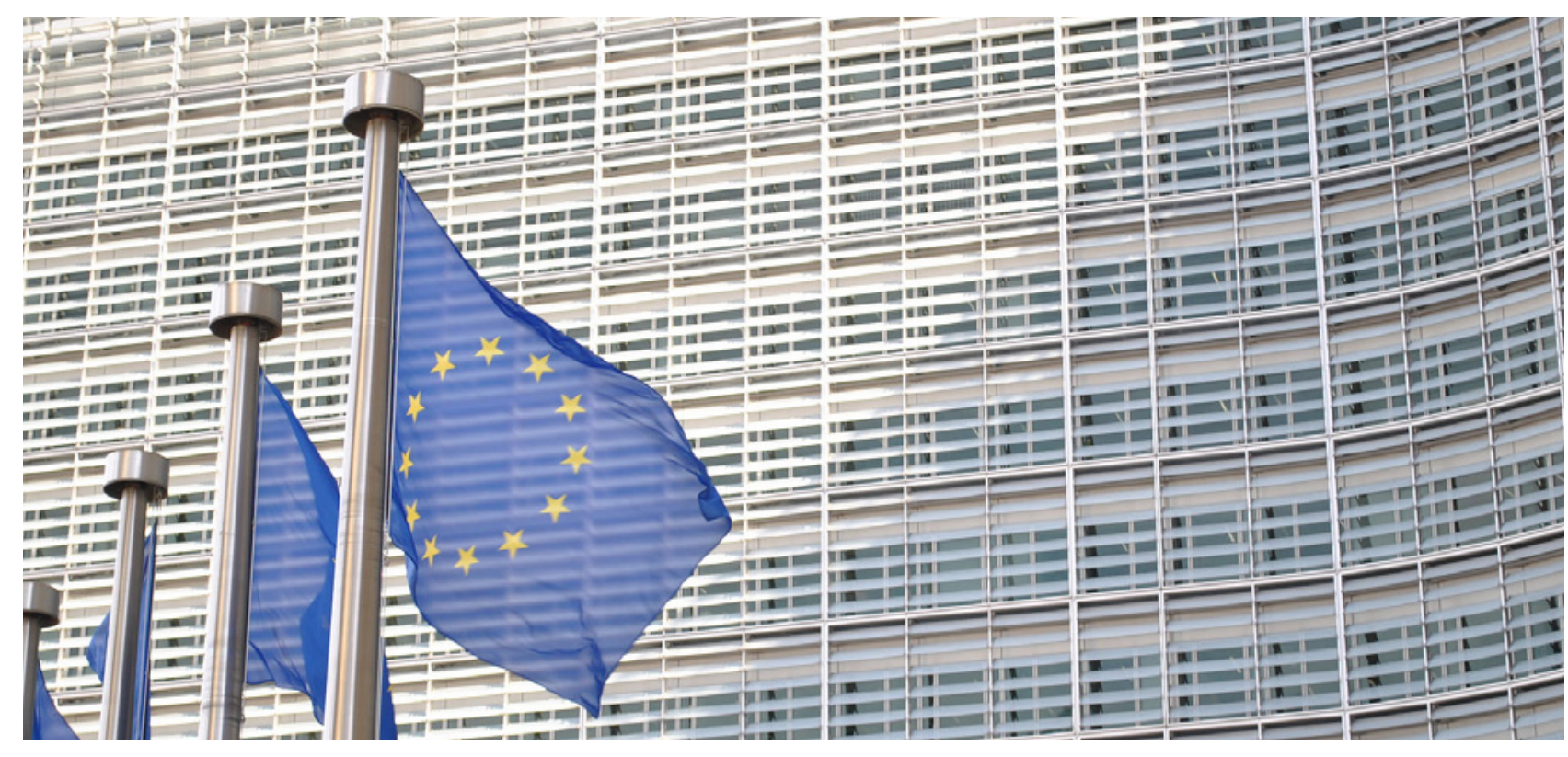

The Global State of Democracy 2019: Addressing the Ills, Reviving the Promise Promise report and the data it builds on directly influenced EU decision-making on democracy. On 14 October 2019, the Council of the European Union formally adopted the new Conclusions on Democracy, which regularly includes a paragraph announcing debates on the state of democracy around the world and EU activities. The adopted text also includes references to priority working areas of International IDEA.

In November 2019, International IDEA's Regional Europe Programme presented The Global State of Democracy 2019 report and data to the EU's Political and Security Committee, which is responsible for the union's foreign and security policy, and to the Council Working Party on Human Rights (COHOM), which determines the EU's human rights and democracy strategy
By organizing events, International IDEA inspired policymakers in the European Union to develop and implement strategies and programmes underpinned by International (DEA's state of democracy analysis, recommendations and data.
Boundary partners Policymakers

Funding:

Core
The presentation to COHOM included a discussion of potentially using the GSoD to create a framework for an annual follow-up to the Conclusions on Democracy at the COHOM or European Council level. International IDEA proposed a periodic evaluation to monitor where the EU stands on implementation, using the GSoD as a benchmarking instrument.

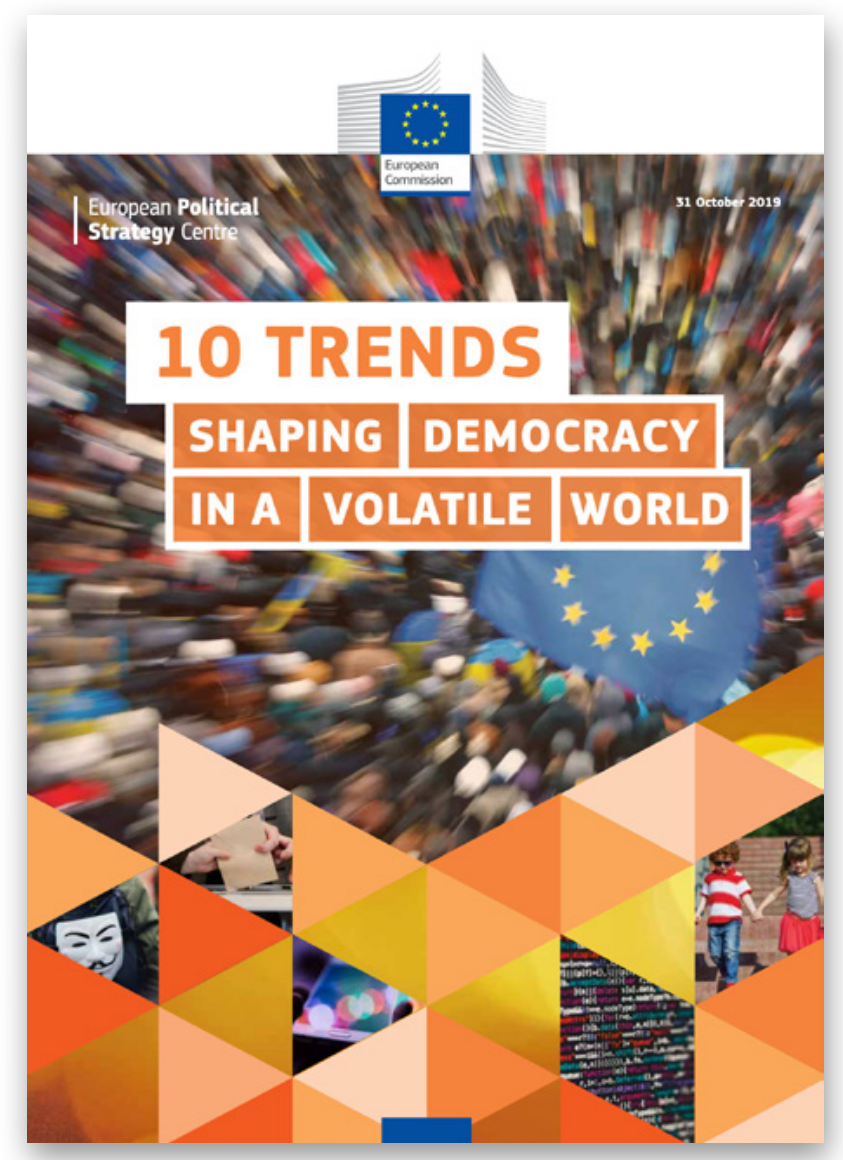

Sources within the European External Action Service and key officials of Permanent Representation to the EU of International IDEA Member States acknowledged the quality of the GSoD indices. They and negotiations of the text of the Council of the European Union's conclusions and other decisionmaking or programming in the field of democracy. In the discussion of council conclusions follow-up it was suggested that the GSoD could be considered a measurement instrument for progress tracking.

The Global State of Democracy indices have also been used as a source for the policy paper, 10 Trends Shaping Democracy in a Volatile World, published by the European Political Strategy Centre in Octobe 2019 confirmed that it was used in the drafting process 


\section{Outcome}

stories 


\section{Supporting excellence in elections: the cases of Nepal and Timor-Leste}

BRIDGE trainings promote personal transformation and institutional change

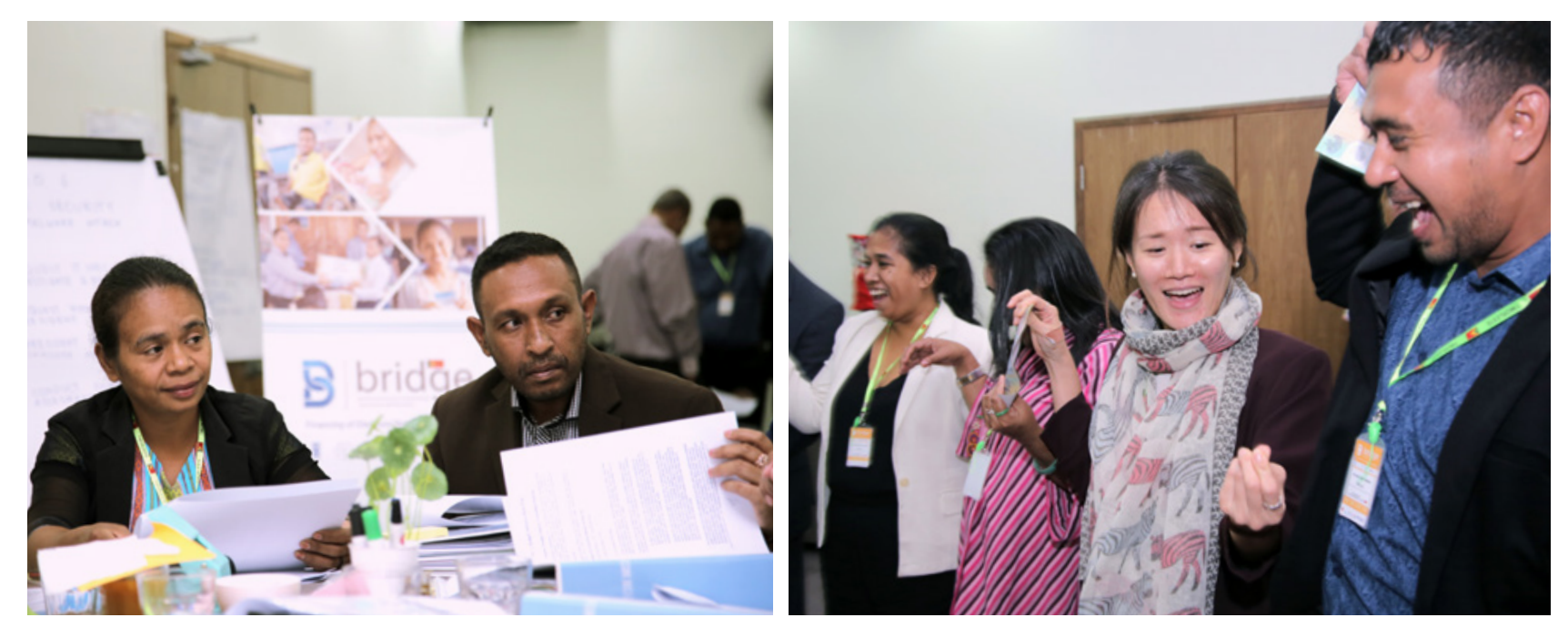

BRIDGE Financing of Elections Regional Workshop, Dili, Timor-Leste, August 2019.

BRIDGE (Building Resources in Democracy, Governance and Elections) is a modular professional development programme with a focus on electoral processes developed by five leading organizations in the democracy and governance field (including International IDEA). The BRIDGE partners have jointly committed to developing, implementing and maintaining the most comprehensive curriculum and workshop package available on this topic.

In Timor-Leste, the Technical Secretariat for Electoral Administration (STAE) and National Election Commission have been implementing BRIDGE since 2001. The commission and STAE have run more than 40 BRIDGE workshops, most recently in August 2019, with the support of International IDEA and the UN Development Programme (UNDP).

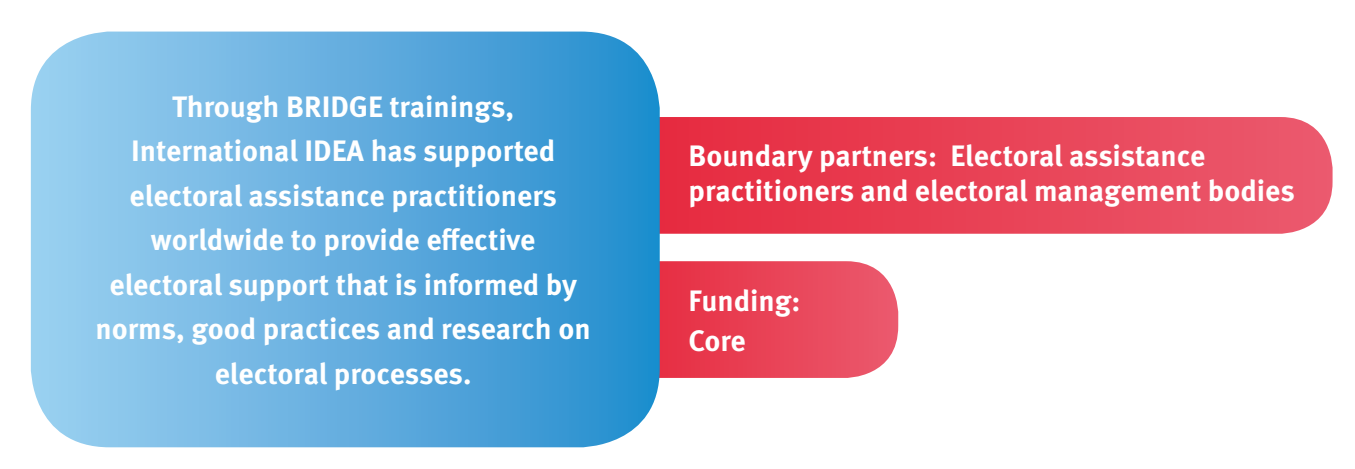

'BRIDGE has been used as a tool to develop the capacity of staff of both electoral management bodies. Most of the election management bodies' staff and most of the senior staff have attended BRIDGE courses.

- August Pereira, advisor at STAE

Over the past 19 years, electoral management bodies around the world have used the BRIDGE curriculum and adult-learning methodology as a professional development tool. During this time, International IDEA and its partners have been responsible for developing, implementing and maintaining the training curriculum, which includes more than 24 modules on electoral administration.

Nepal has also used the tool as part of its broader capacity development framework. The Election Commission of Nepal (ECN) has been implementing BRIDGE since 2008 with support from International IDEA, the UNDP and the International Foundation for Electoral Systems (IFES). The ECN ran 87 workshops using various BRIDGE modules for 1,912 participants between 2008 and 2016. According to a 2018 evaluation report commissioned by the UNDP, 'a deep commitment to BRIDGE was demonstrated by past and present Commissioners and Secretaries' and 'there has been both positive personal transformation and institutional change'. The report also mentions that 'there has been a demonstrated paradigm shift in the ECN's training modality'.

'[The programme has] helped ECN to move from an outdated training methodology to a more modern form and comprised a sort of self-actualization for those who took part. BRIDGE has changed the learning landscape of the ECN.'

- Former election commissioner, Election Commission of Nepal

The UN Secretary-General recently described BRIDGE as a 'key platform for building electoral capacity and institutional memory'. In 2020, the BRIDGE partners will launch an updated curriculum-BRIDGE Version 3as part of the project's 20 th anniversary. 


\section{Outcome stories}

ELECTORAL

PROCESSES

\section{Trailblazing electoral risk management}

Electoral management bodies are increasingly institutionalizing risk

management to strengthen their capacity to deliver trusted election results

\section{i̊n ERMTool}

ELECTORAL RISK MANAGEMENT TOOL Commission and International IDEA, revealed that the Institute's work on electoral risk management has had a significant influence on the electoral practices of several electoral management bodies (EMBs). For example, Bosnia and Herzegovina, Botswana, Namibia, Nepal and Nigeria have either institutionalized risk management processes or have asked for training materials on how to do it.

When this work began in 2009, the Institute's focus was on the prevention and mitigation of election-related violence. However, we soon realized that our comprehensive risk management method could be more broadly applied.

Testing and piloting of the Electoral Risk Management Tool (ERM Tool) by partner organizations in Bosnia and Herzegovina, Colombia, Kenya and Sri Lanka between 2010 and 2013 proved the point. The tool ensured that risks are not addressed in a silo, but through multi-faceted dialogue and interagency collaboration that promotes information sharing, conflict sensitivity and cost effectiveness.

Since the ERM Tool's launch in 2013, International IDEA has supported more than 20 EMBs worldwide on its use; most have adopted the tool, including those from Nepal and Nigeria. We have shared over 300 software licences

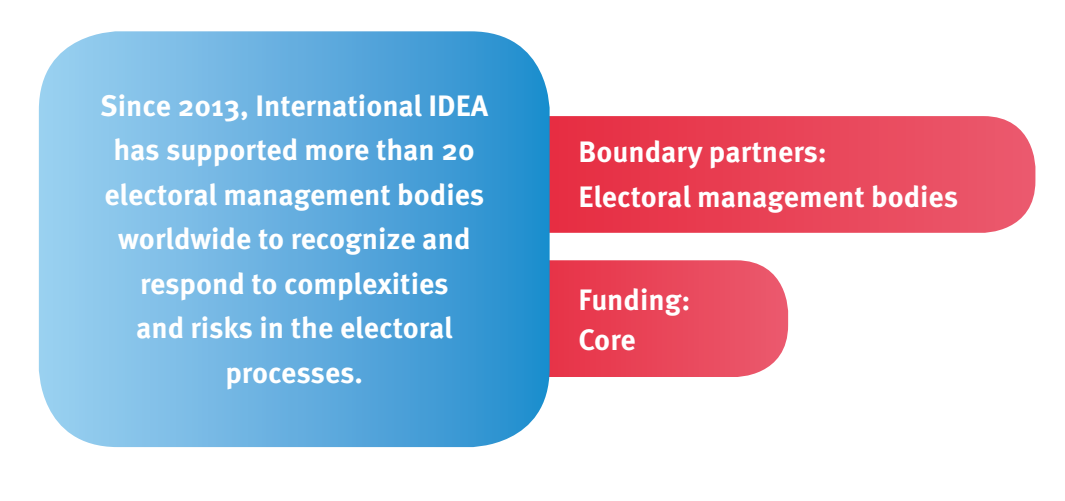

$2013 \quad 2019$

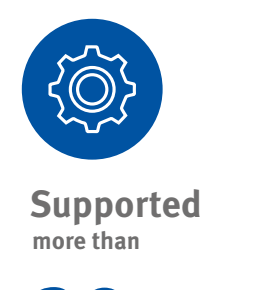

\section{0}

EMBs worldwide

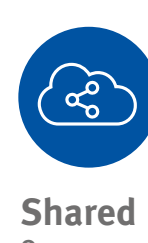

300

Software licences

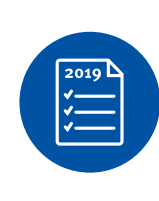

2019

60

Approved requests

with EMBs, civil society organizations, international non-governmental organizations and researchers. Over 60 such requests were approved in 2019 alone. According to Kesego Sei Sekgwama, the performance improvement coordinator at the Independent Electoral Commission in Botswana: 'Although Botswana has never experienced election-related violence, the imperative for the commission and senior management is to be aware of these risks in order to make informed strategic decisions.

International IDEA's work on this topic is shaping the practices of national and international electoral stakeholders. This influence is demonstrated by the interest and positive feedback from partners including the Independent National Electoral Commission of Nigeria, those interested in collaboration, such as the Central Election Commission of Palestine, and feedback from our Building Resources in Democracy and Governance (BRIDGE) partners in Nepal.

This programme's work is also influencing a broader group of stakeholders with which the Institute has not directly engaged. For example, Academy Halogen used the policy paper on Risk Management in Elections to frame multi-stakeholders' expert discussions that rated risks and provided recommendations before the 2019 general elections in Nigeria. 


\section{Working to enhance electoral regional cooperation in Melanesia}

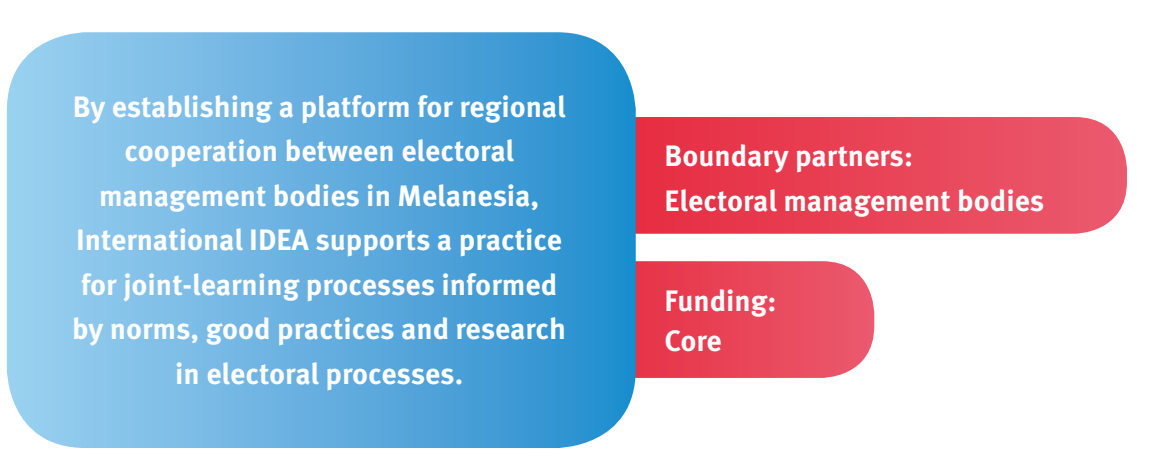

New network will provide joint trainings,

strengthening electoral institutions and processes

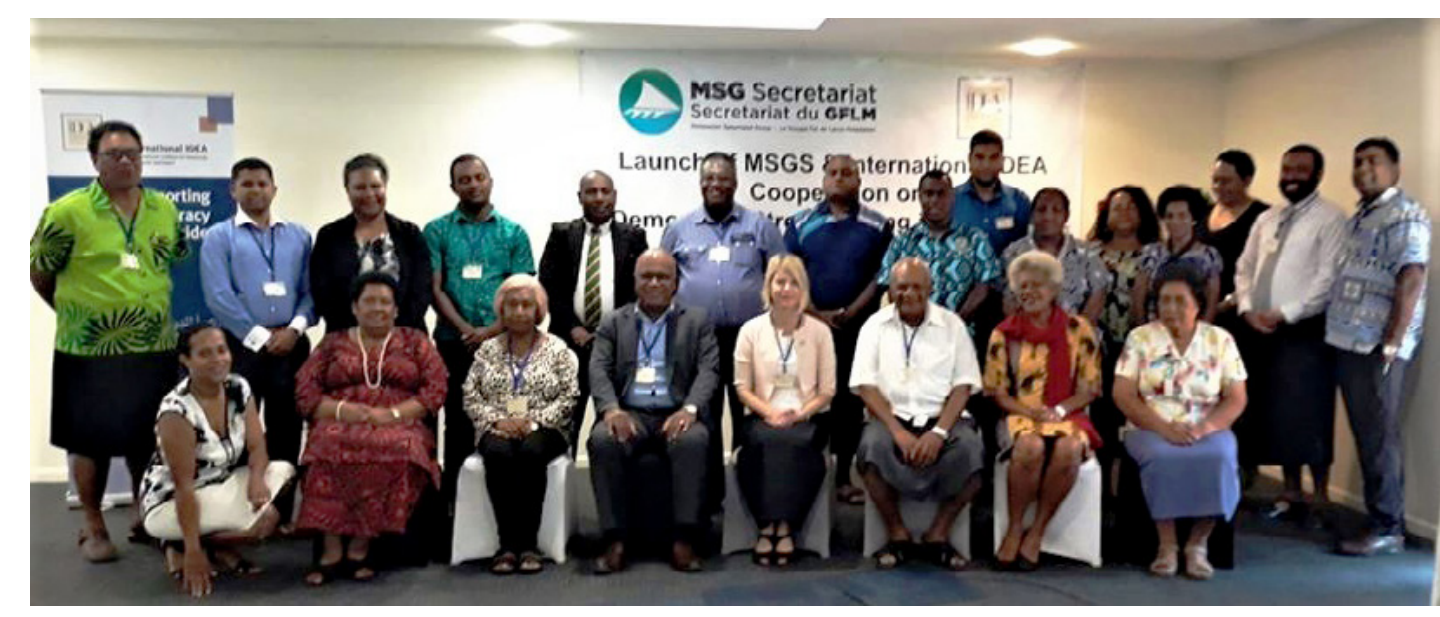

Seated fourth from left, Director General of the Melanesian Spearhead Group Secretariat, Ambassador Amena Yauvoli. To his left is the International IDEA Regional Director for Asia and Pacific, Leena Rikkilä Tamang.

International IDEA seized the opportunity to increase our cooperation with the Melanesian Spearhead Group Secretariat (MSGS), an intergovernmental group promoting economic growth and good governance among its member states. Following the signing of a memorandum of understanding between International IDEA and the MSGS in February 2019, several areas of possible cooperation were quickly identified. The two organizations then held several events to improve regional cooperation and knowledge sharing.

The first event, held in September, gathered government officials, political party representatives, electoral management bodies (EMBs), and civil society organizations in Honiara, Solomon Islands to mark the official launch of the MSGS-International IDEA cooperation. This consultation then inspired the MSGS and the Fijian Elections Office to work with International IDEA in organizing a conference for EMBs in all member states. Representatives from Fiji, Papua New Guinea, Solomon Islands and Vanuatu attended. During the two-day conference participants identified commonalities and differences in electoral practices.
As a direct result of the conference, relationships between the EMBs in the region were strengthened as the Association of Election Management Bodies in Melanesia was formed with the MSGS serving as its secretariat. The association will enable the region's EMBs to learn from one another and will set up a mechanism for joint trainings, and sharing staff when needed.

This strengthened regional cooperation among EMBs will benefit electoral institutions and processes in the Melanesian region. International IDEA will also have a role to play.

'International IDEA has immense resources and technical expertise. Our young association would definitely benefit a lot from the technical guidance and resource materials that it can produce.'

- Mohammed Saneem, supervisor of elections, Fiji

With the new association in place, International IDEA began a series of trainings to strengthen the capacity of the MSGS in its election observation mission. In October 2019, the Institute developed a comparative research publication on the various election observation methodologies employed by other regional organizations and international non-governmental organizations. The report was delivered along with a training session at MSGS in Port Vila, Vanuatu on 5-6 November 2019.

'I wish to extend the training to our members so that they would be able to know and articulate what is important to observe during elections.'

I would like to thank International IDEA for your [forthrightness and] for your willingness [in] coming through with the MoU that we signed in February, which will continue to feature itself prominently in our discourses to strengthen election management in Melanesia through the [MSG] Secretariat. [...] All in all, I think the partnership is very strong, very formidable and going forward I would like to continue to build it up.'

- Ambassador Amena Yauvoli, Director General of Melanesian Spearhead Group Secretariat 


\section{Building a cyber-resilience mindset}

Recognizing complexity and risks in electoral

processes to inform new initiatives and solutions

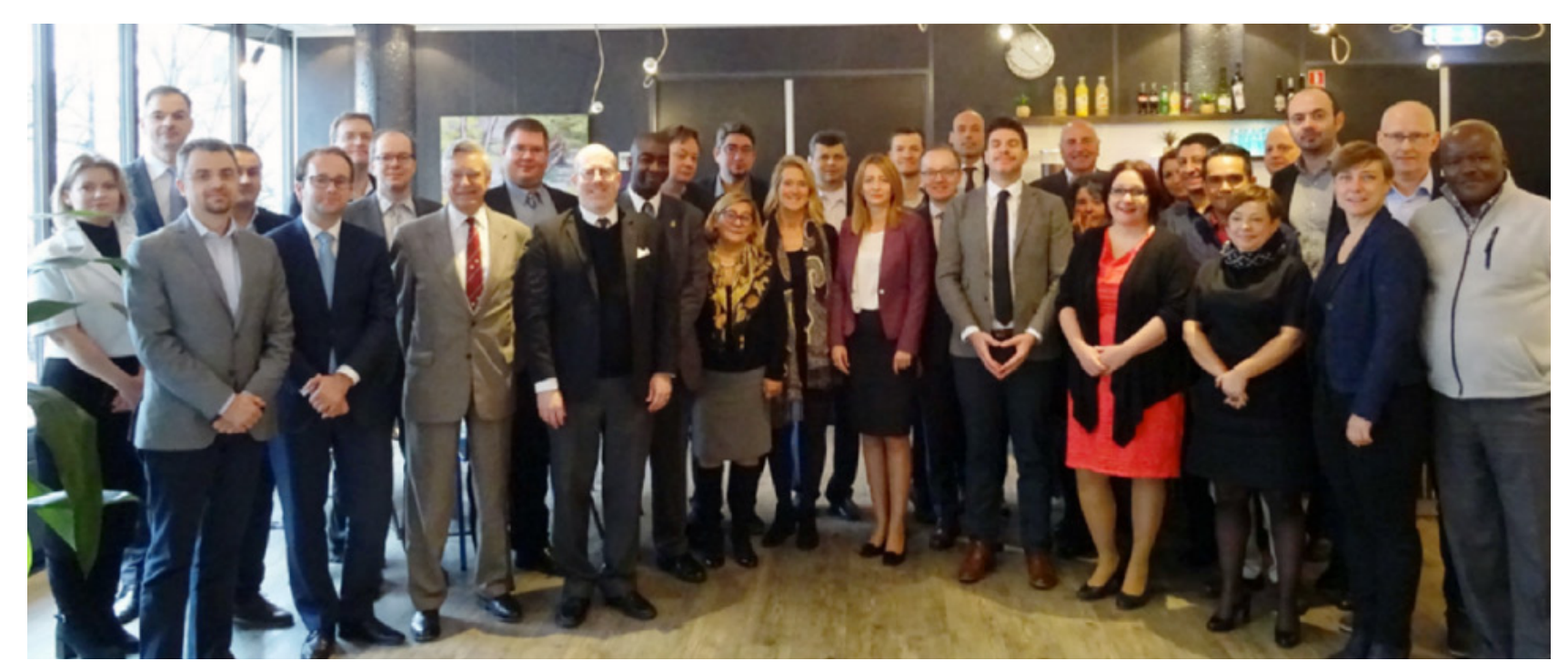

Participants of the cybersecurity in elections round-table discussion hosted by International IDEA in the Hague in November 2019.

In November 2019, the Commonwealth Secretariat shared its first draft of the Good Electoral Practice Guide on Electoral Cybersecurity, which is designed to shape the approaches of many election administrations of the 53 Commonwealth member states to protect their elections from cyberthreats. The guide draws on International IDEA's recent work on cybersecurity as well as a range of International IDEA electoral knowledge resources.

This publication is an example of how International IDEA's knowledge products contribute to norm building and new practices through regional organizations. The Commonwealth guide directly draws on the analysis, findings and recommendations from International IDEA's cybersecurity work. It recommends interagency cooperation, citing International IDEA's publication Cybersecurity in Elections: Models of Interagency Collaboration as evidence of the need for multi-stakeholder collaboration and lists the multiple models of interagency collaboration identified by International IDEA. Similarly, as advocated in International IDEA's report on the Certification of ICTs in Elections, the Commonwealth stresses the importance for electoral management bodies to recognize the separate stages of the electoral cycle in planning and delivering electoral processes.
Through knowledge products and events, International IDEA has supported electoral assistance practitioners from more than 25 countries to learn about recent good practices and research on cybersecurity in elections. This helped them to adapt new practices and research to their local context.
Boundary partners: Policymakers,
electoral assistance practitioners

Funding:

International IDEA held a series of expert meetings and face-to-face interviews with election administrations and cybersecurity expert bodies between early 2017 and 2019. These activities allowed participants from nearly 25 countries to directly exchange experiences and discuss best practice in this domain. Several participants provided informal feedback confirming that what they learned was immediately applied in their countries, sometimes leading to significant improvements in and changes to their electoral practices.

The findings and recommendations have also, in the space of a few months, informed a range of initiatives underway including the Kofi Annan Global Commission, an International Foundation for Electoral Systems white paper, EU processes and the Commonwealth good practice guide.

'Governments should cooperate on electoral cybersecurity via the Commonwealth, regional cooperation organisations such as CARICOM, ASEAN, the Organization of American States (OAS) and the Organization for Security and Co-operation in Europe (OSCE), and other intergovernmental bodies such as the International Institute for Democracy and Electoral Assistance (International IDEA):

- Commonwealth Secretariat, Good Electoral Practice Guide on Electoral Cybersecurity

Through these forums, International IDEA advocates a long-term, systems approach in which electoral cybersecurity is viewed as critical infrastructure that relies on the competence of officials, interagency collaboration and risk management habits.

As technology is introduced into each aspect of electoral preparations, from candidate financing disclosure software to polling operations data, electoral processes are vulnerable to hacking, even in countries with paper-based voting Cyber-resilience refers to an electoral system's ability to deal with shocks and stresses while continuing to operate in this environment. This holistic approach recognizes that managing public perceptions of cyberthreats to an electoral process is as important as defending against actual threats, which in turn means including political parties and civil society agencies at each step—both through cooperation and the free flow of information. 


\section{Dutch state commission uses International IDEA recommendations on digital microtargeting}

International IDEA provided input on digital microtargeting as

long-term electoral support to reduce invalid votes

\section{IDA}

Digital Microtargeting Political Party Innovation Primer1

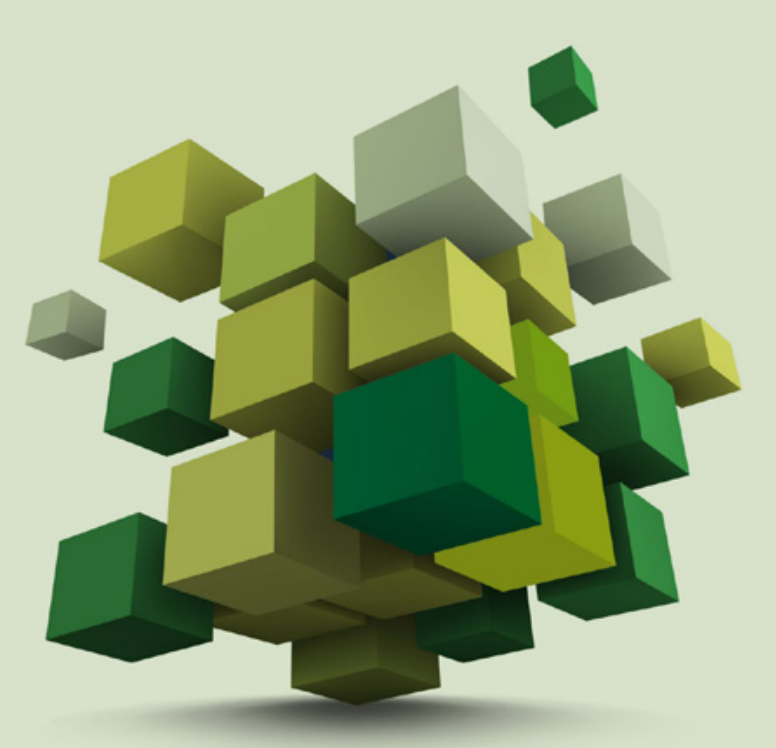

Microtargeting is a marketing strategy used by political parties. It analyses people's data to segment them into small groups that can be targeted with tailor-made online political advertisements.
In December 2018, the Dutch State Commission on the Parliamentary System published its report on the ability of the parliamentary system to adapt to societal changes. The report bases several of its recommendations related to political microtargeting on input provided by International IDEA, as announced by the commission's secretary. Before the report was published, International IDEA met with the commission several times to provide written and verbal input-especially to the sections on political microtargeting. International IDEA based its input on its publication on Digital Microtargeting, its past events with European and US political parties on digital innovations in political parties; and its work with international microtargeting experts to support political parties in several European countries.

The Dutch government, in its response to the commission's report in June 2019, announced it will adopt the commission's microtargeting recommendations and introduce regulations in a new political parties law to preven the spread of inaccurate or biased information during election campaigns.

As a follow-up, International IDEA organized an international microtargeting round-table for European oversight agencies, co-hosted by the Dutch Ministry of the Interior. The round-table unpacked the commission's recommendations by inviting representatives of European oversight agencies from Germany, the Netherlands and the United Kingdom to compare their practices of oversight enforcement. 
ELECTORAL PROCESSES

\section{Increasing Myanmar election staff's understanding of rules and regulations will be key for a successful 2020 election}

Training manual builds capacity ahead of the general elections in Myanmar

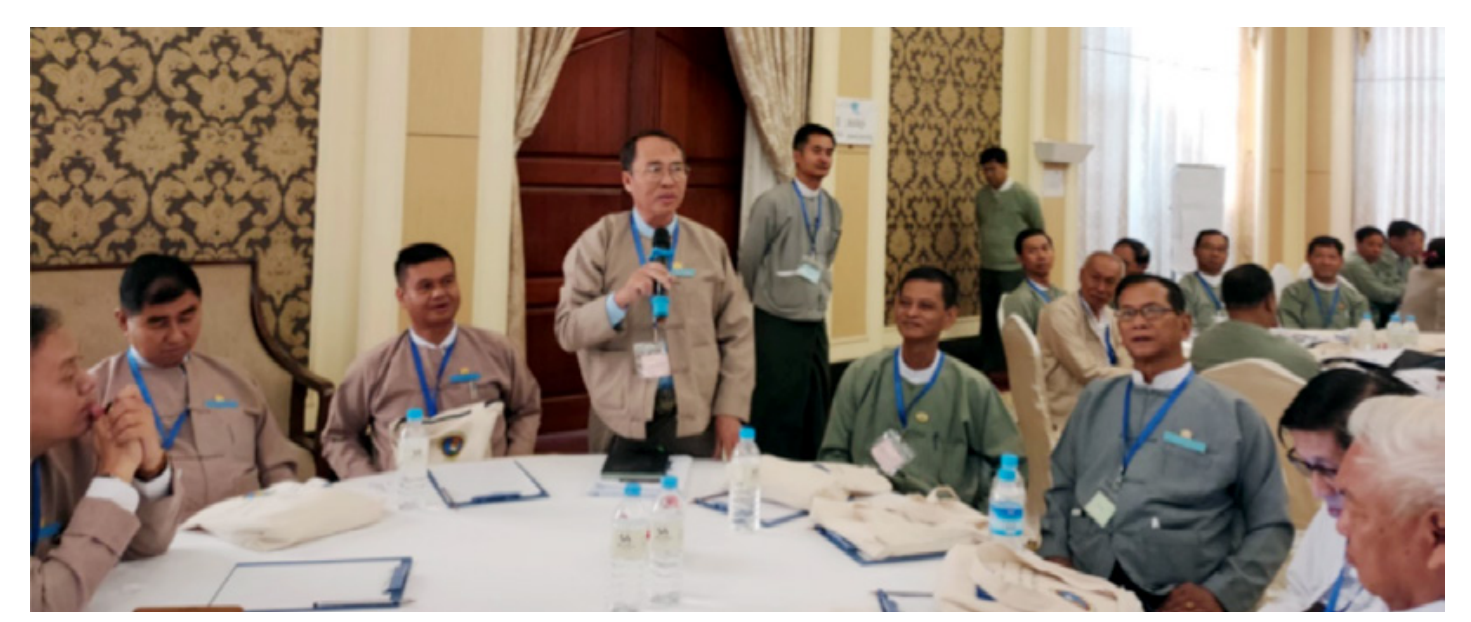

Myanmar officials discuss the trainings and manual for electoral subcommissions and polling station staff.

The transfer of power to a democratically elected government, which came about through Myanmar's first historic 2015 general election, was a milestone in the country's transition to democracy. Since 2015. International IDEA has been working to support the process of democratization through the European Union-funded 'Support to Electoral Processes and Democracy (STEP Democracy)' programme.

As Myanmar prepares for its second general election, the Union Electoral Commission (UEC) has developed a training manual to give election staff a better understanding of the rules and regulations that are key to a successful election and the sustainability of Myanmar's democratic institutions.

The UEC will use the manual—developed through the STEP Democracy programme-to supplement trainings for all levels of electoral subcommissions and polling station staff, to increase their knowledge and understanding of electoral rules and regulations, which is a cornerstone for a successful election in 2020.

Photo credit: International IDEA
This STEP Democracy programme has worked closely with the UEC, political parties and civil society organizations to foster a deeper awareness of, advocacy for, and reform to the legal framework behind the administration of the 2015 election. The project provided trainings for the UEC and all new subcommission and polling station staff, enhancing their capacity to fulfil their electoral duties ahead of the by-elections held in 2017 and 2018.

The new manual is the next step in supporting the UEC and election staff to ensure a successful election in 2020. It has served as the basis for 'training the trainers'. Qualified UEC commissioners provided training for 303 selected subcommission members from 79 districts on how to use the manual; these newly trained subcommission members in turn trained approximately 2,300 newly appointed election sub-commission members.

'This training helps us to upgrade our knowledge of electoral process. We got to share our respective situations and experiences from our state and region. Also, we could discuss those issues with trainers from UEC head office. Now, we feel more confident and we want to deliver the cascade trainings soon.'

- Subcommissioner from Kayin State

Topics covered include the role and responsibilities of the UEC; legal framework; political party Codes of Conduct; voter registration; resolving, negotiating and submitting an election objection; advance voting; public and voter education; counting and announcement of results; the role of sub-commissions; and working guidelines for polling stations and gender mainstreaming.

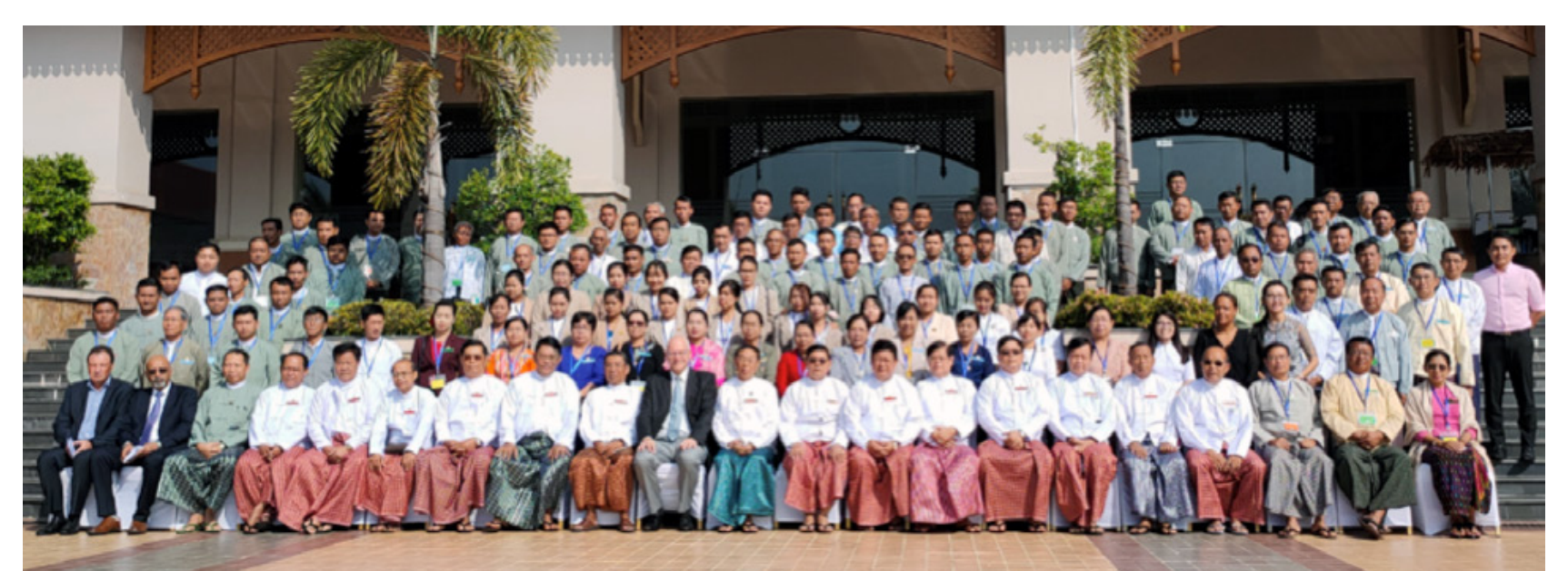

Group photo of Myanmar's Union Electoral Commission chair, commissioners and sub level commissioners, and International IDEA representatives. 


\section{Forging a state and civil society partnership on electoral processes in Fiji}

Preparing the foundation for a partnership to support Fiji's electoral institutions and processes

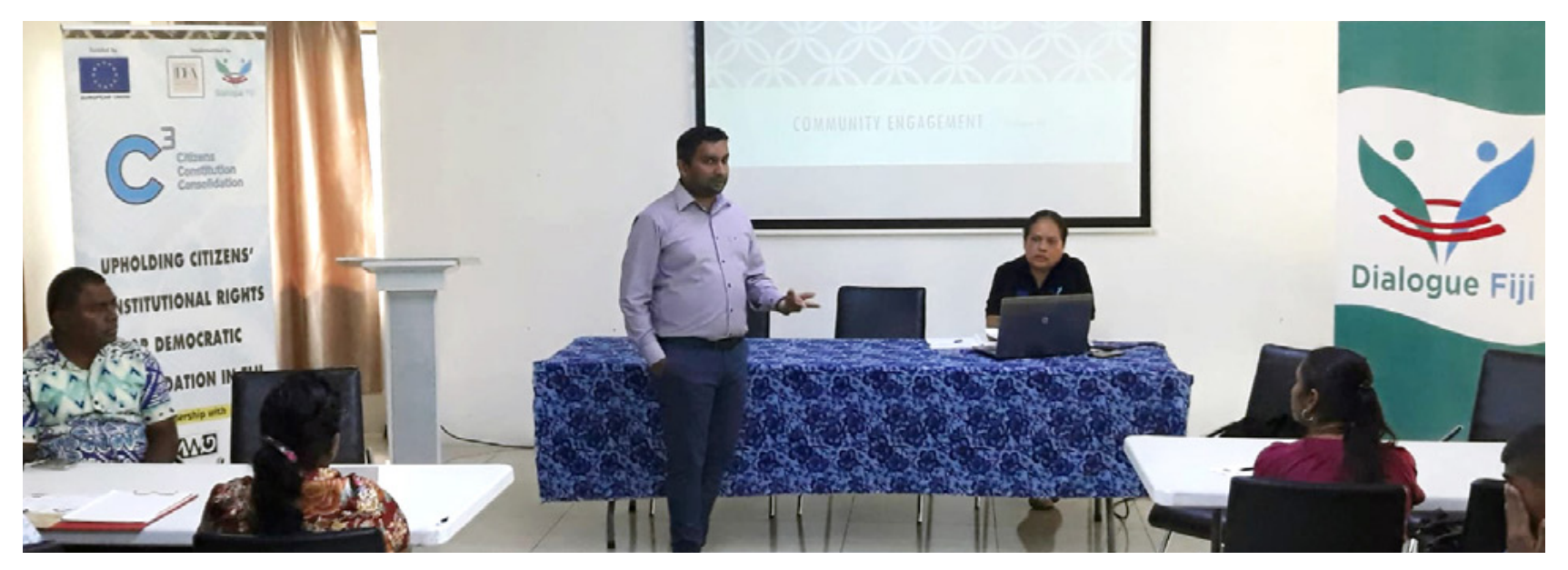

Dialogue Fiji, one of the $\mathrm{C}_{3}$-Fiji Project partners, organized a public forum in Sigatoka under the $\mathrm{C}_{3}$-Fiji Project in which community leaders interacted with officials from the Ministry of Rural Development to discuss development and socio-economic problems.

Fiji held its first democratic elections in 2014, following the 2006 coup d'état. But tensions and a lack of dialogue between the country's CSOs and electoral management body led to a serious lack of trust in its electoral process.

Under the European Union-funded project, 'Upholding Citizens' Constitutional Rights for Democratic Consolidation in Fiji (C3-Fiji)', International IDEA is working to bridge the gap and create a dialogue between these two key players. The project started in 2018, ahead of that year's general elections, and will continue through October 2020.

At the suggestion of the supervisor of elections, Mohammed Saneem, the Institute supported the establishment of a formal partnership between the Electoral Commission, the Fijian Elections Office and several interested CSOs as a platform for collaboration.

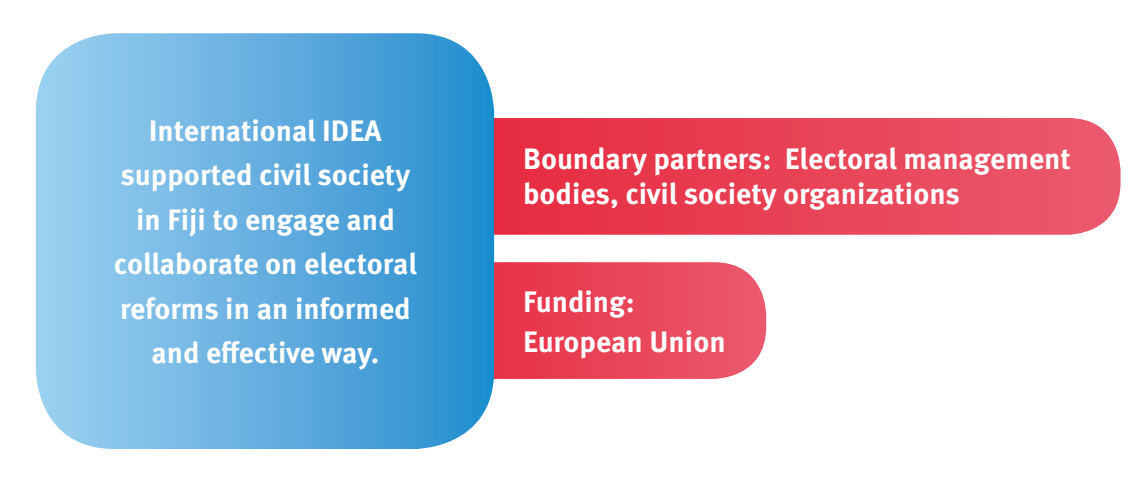

The partnership will review the legal framework of Fiji's electoral institutions and processes and provide recommendations on how to improve electoral policies and practices. In addition, the partnership aims to increase civil society participation in conducting voter education with the guidance of the Fijian Elections Office. It also provides opportunities to familiarize CSOs with election observation methodologies and practices, and to prepare them to observe future elections.

The partnership's terms of engagement are currently under development, but it has already produced a notable change in relationships between the EMB and civil society in Fiji, according to Florence Swamy, executive director of the Pacific Centre for Peacebuilding, one of C3-Fiji project partners.

'International IDEA in this process had a solid role. They were making a strategic partnership with the [Fijian Elections Office] but also, they were bringing together locally, partners that weren't working together and we were able to feed off each other to deliver our programs quite well.'

- Florence Swamy, executive director, Pacific Centre for Peacebuilding (a C3-Fiji project partner)

The supervisor of elections has also praised the initiative.

International IDEA has provided us immense expertise as well as resource material in terms of the running and conduct of elections. We feel very much appreciated as a small election management body. This gives us a lot of encouragement in terms of our partnership. I am very, very grateful for the programmes that we have run in the last [electoral] cycle and I am looking forward to using the services and expertise of International IDEA to further the activities planned for the next cycle.'

- Mohammed Saneem, supervisor of elections 


\section{Improving mechanisms to enhance electoral regulatory frameworks in the Southern African Development Community}

Focusing on electoral dispute resolution and political finance systems

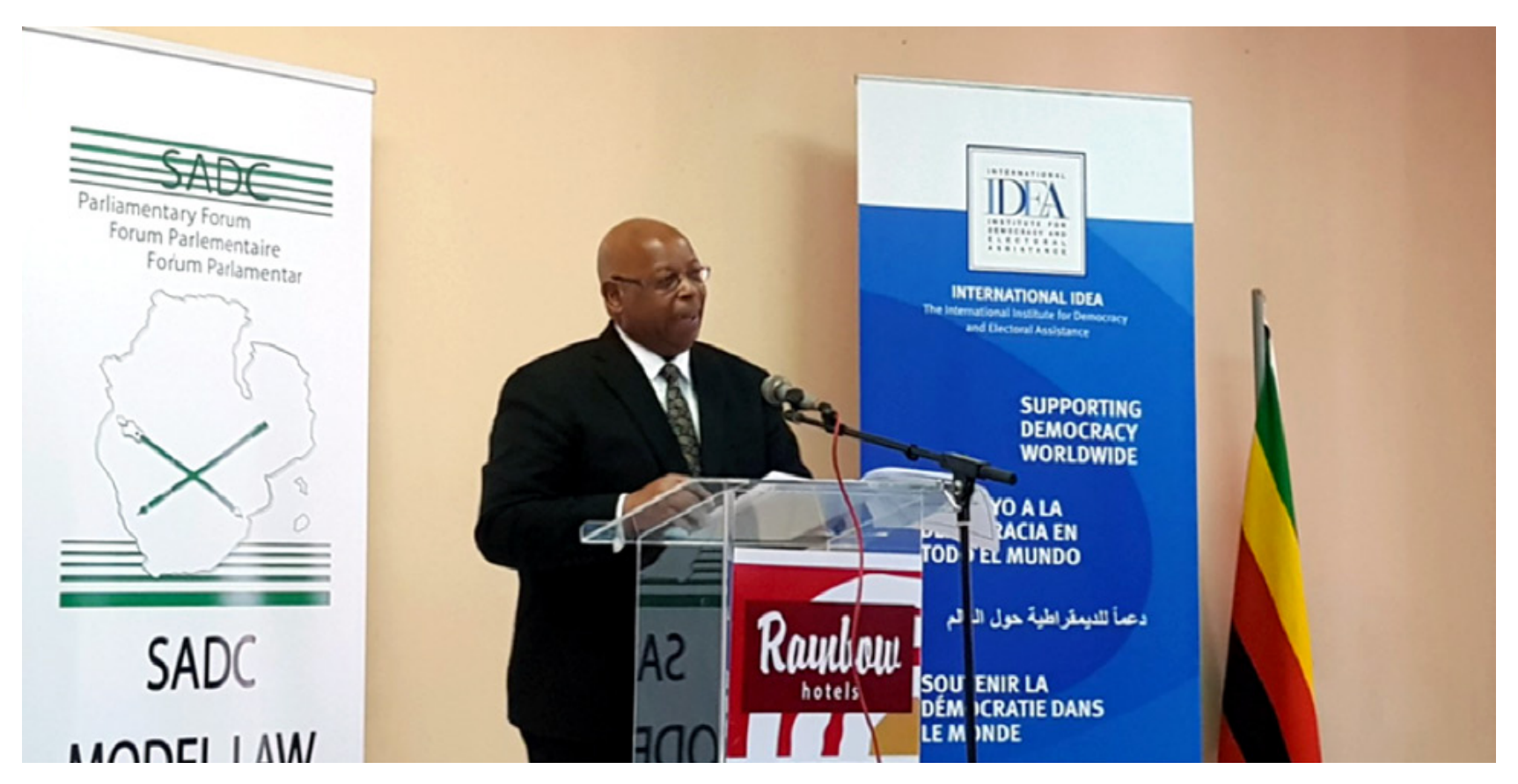

Speaker of the Parliament of Zimbabwe, the Honourable Jacob F. Mudenda, addressing delegates at a policy dialogue session.

Following the successful adoption of the Southern African Development Community's (SADC) Model Law on Elections in December 2018, International IDEA has supported national parliaments in the SADC region to implement electoral reforms and align their practices with the Model Law.

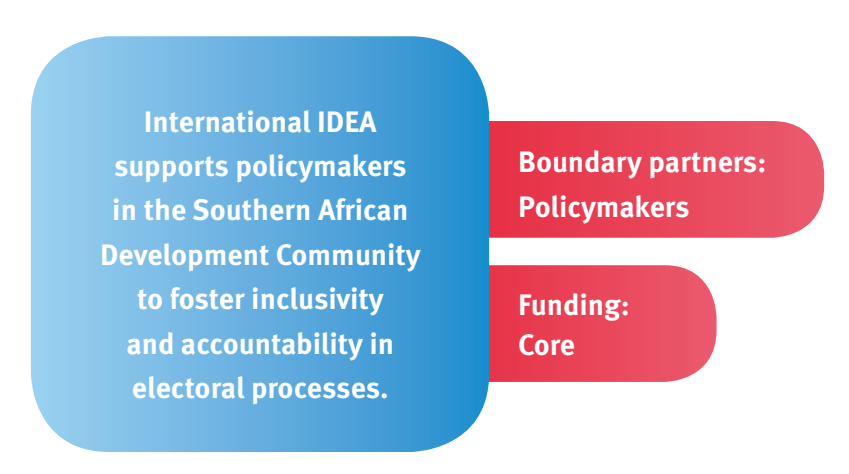

As part of this work, the Parliament of Zimbabwe with support from International IDEA's Africa and West Asia Programme, hosted a policy dialogue to reflect on political finance systems and electoral dispute resolution mechanisms in November 2019. Parliamentarians and election experts from the region attended the event, as well as representatives from Zimbabwe's media and civil society. Such efforts have an especially positive impact in Zimbabwe, which is currently finalizing its electoral reform process ahead of the 2023 general election.

During the dialogue, the speaker of the Parliament of Zimbabwe asked local CSO representatives to revise their proposals on electoral reform submitted to parliament and align them with the SADC's Model Law. International IDEA's policy paper, The Integrity of Political Finance Systems in Africa: Tackling Political Corruption, served as a reference document for the dialogue.

Work on the SADC Model Law started in 2016 to hasten the implementation of various principles, guidelines and obligations on democratic elections. Previous regional election instruments were not legally binding and were therefore unenforceable. Since 2017, following an invitation from the SADC Parliamentary Forum, International IDEA has actively participated in the consultation, development and review processes. 


\section{Establishing the Arab Network for Women in Elections}

Regional cooperation to promote women's political participation through mainstreaming policies and identifying standards and good practices

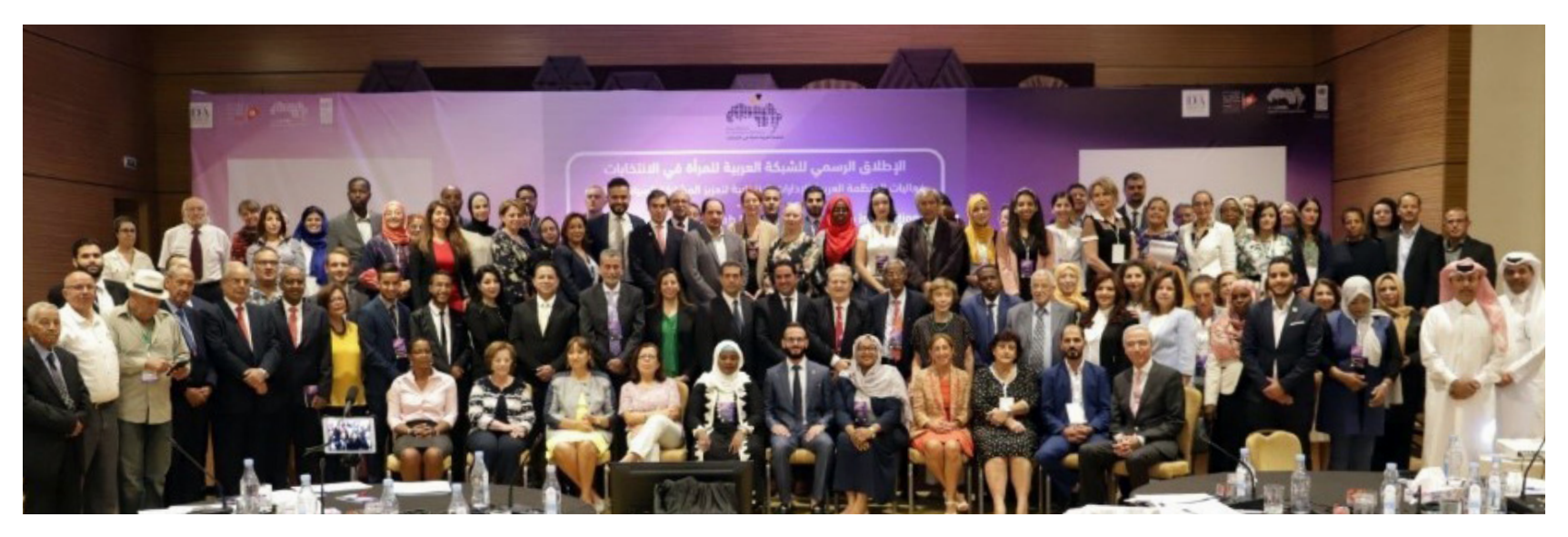

The launch of the Arab Network for Women in Elections in Tunis on 5 October 2019.

The Arab Network for Women in Elections was officially launched on 5 October 2019. As the first and only entity of its kind in the region, the network provides a platform to support and promote women's political and electoral participation in the Arab world.

It advocates gender mainstreaming in the policies and programmes of all stakeholders, partners and members; supporting women in political and electoral processes; and identifying and disseminating standards and goo practices for women's participation in the region.

International IDEA has partnered with the Arab Organization for Election Management Bodies and the UNDP to create this regional platform to promote gender equality in elections. The network brings together governmental and non-governmental organizations and individuals that share the same vision.
International IDEA supports the Arab Network for Women in Elections to promote the political and electoral participation of women in the Arab region with the aim to make the representation functions and institutional systems more transparent, inclusive, responsive and accountable to all citizens.
Boundary partners: The Arab Network for Women in Elections (consisting of electoral organizations, electora

Funding: Core

Despite recent advances in promoting women's political representation, women in the Arab region remain underrepresented. Many face barriers to participating in public and political life in general and in elections, in particular. The region has the lowest average of female Members of Parliament worldwide (19 per cent).

The recently launched network is a continuation and expansion of International IDEA's work to promote gender equality. For several years we have been working with electoral management bodies (EMBs), MPs, political parties, civil society organizations, international electoral assistance providers and other boundary partners to increase women's participation in politics at all levels.

The network is a good example of impactful coordination among governmental and non-governmental stakeholder across countries, as it involves a variety of electoral stakeholders. 


\section{Mexico: International IDEA renews commitment to promote access to electoral justice}

As a founding member of the Global Network on Electoral Justice, International IDEA addresses electoral justice and equality

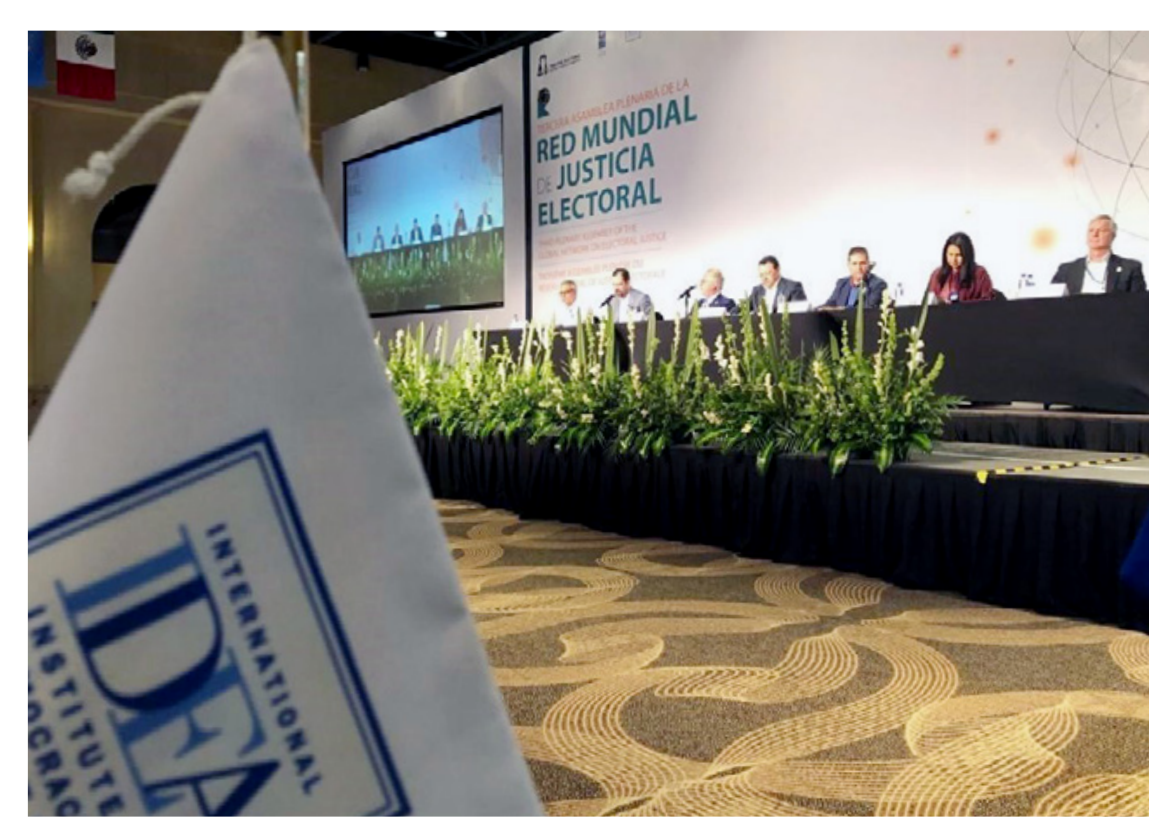

he plenary assembly of the Global Network of Electoral Justice held in November 2019 in Los Cabos, Mexico.

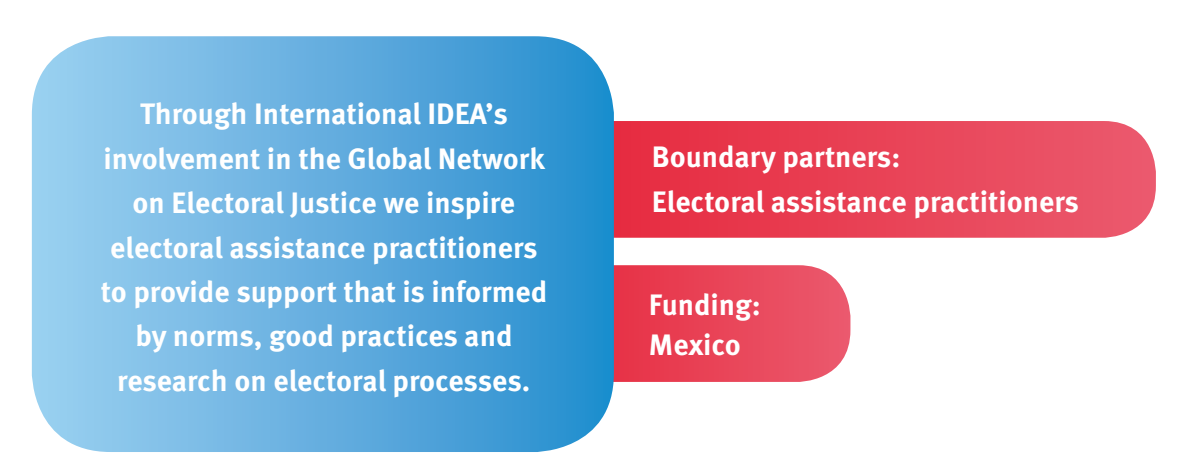

International IDEA supported the TEPJF-hosted 3rd Plenary Assembly of the GNEJ in Los Cabos, Mexico More than 115 experts from 32 countries and various judicial and administrative electoral authorities, international organizations, academic institutions and think tanks gathered to address democracy's most pressing challenges. Some of the institutional participants included the Organization of American States, the UNDP and the International Foundation for Electoral Systems. Moreover, specialists from top universities and think tanks, such as the universities of Lille, Siena and Madrid and the Getulio Vargas Foundation in Brazil joined discussions as part of a cutting-edge scientific committee.

The plenary assembly of the GNEJ was a strategic event not only to discuss the most pressing challenges facing democracy but also, and more importantly, to raise awareness and find solutions for these issues. Therefore, panels and working groups proposed solutions to key areas including equal access to justice, democracy and corruption, democratic disaffection, money in politics, and the participation and representation of minority groups in public decision-making.

During the plenary, Daniel Zovatto, International IDEA's Director for Latin America and the Caribbean, focused on the main results and findings of the Latin American electoral super cycle, with a special emphasis on the gender parity challenges within the region, noting the absence of women among elected presidents.

Miguel Ángel Lara Otaola, head of International IDEA's subregional Office for Mexico and Central America, chaired the group on 'Equality for the political inclusion of vulnerable groups', where he emphasized the importance of using international law (the Universal Declaration of Human Rights, the International Covenant on Civil and Political Rights and the Convention on the Elimination of all Forms of Discrimination Against Women, amongst others)—which has already been ratified by most countries— to guarantee political and electoral rights at the national and local levels.

International IDEA's subregional office for Mexico and Central America also regularly shares polic recommendations and position papers on the GNEJ online platform. Since its launch, the office has contributed over 20 articles, notes and policy papers on a range of topics including democratic disaffection, political financing equal access to electoral justice and political participation, and digital technologies and elections. partnership with the Electoral Tribunal of the Federal Judiciary of Mexico (TEPJF). Since the inception of the GNEJ in 2017, the TEPJF and International IDEA have been key partners with one objective in mind: the effective protection of citizens' political-electoral rights. As a result, International IDEA and the TEPJF have focused on strengthening and building sustainable practices to protect the political and electoral rights of women, indigenous groups, people with disabilities, and the LGBT community. For instance, the publication of Access electoral justice in comparative perspective, which highlights good practice and relevant examples of how election dispute resolution bodies (from specialized tribunals to high courts) can guarantee the electoral rights of these groups and individuals. in the Global Network on Electoral Justice (GNEJ) is knowledge, pool of experts and inby organizing and participating in events, providing advisory services and producing knowledge products and publications.

Photos credit: International IDEA 
CONSTITUTION-BUILDING PROCESSES

\section{Supporting Bangsamoro Autonomous Region in Muslim Mindanao at a critical juncture}

Supporting an inclusive approach for democratic institutions and processes in a post-conflict region

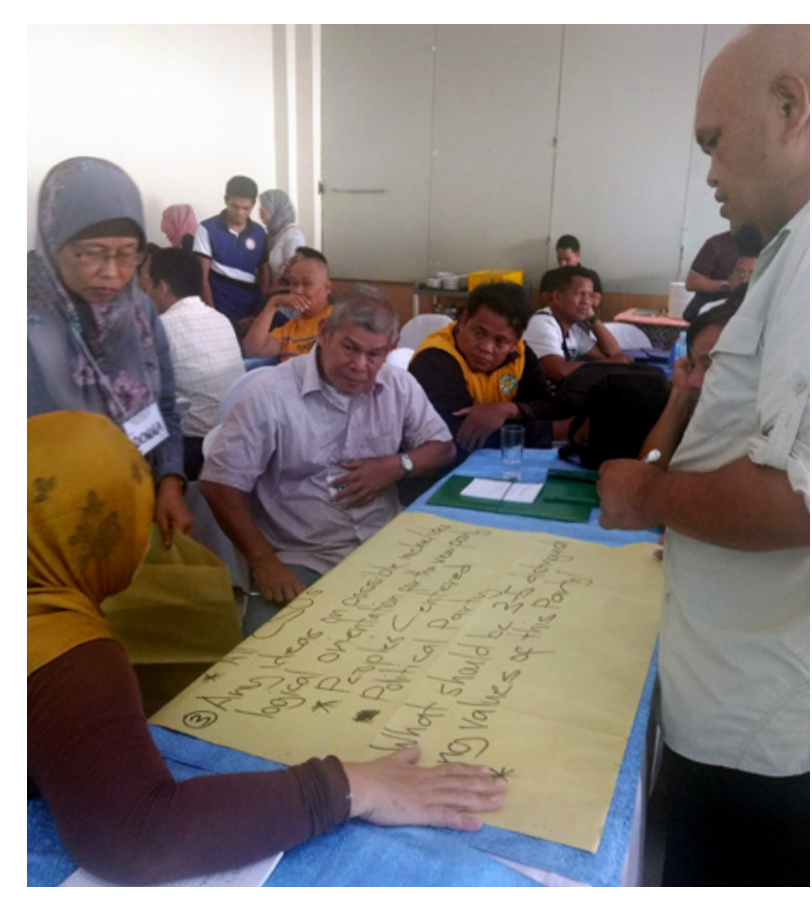

In early 2019, the citizens of Bangsamoro Autonomous Region in the Philippines voted in favour of the Bangsamoro Organic Law, which began the transfer of power from the previous regional government to the newly formed Bangsamoro Autonomous Region in Muslim Mindanao (BARMM) and hence ending the previous regional government of the Autonomous Region of Muslim Mindanao (ARMM).

The new law led to the formation of an 80-member transition authority-appointed by the Philippine president and led by Interim Chief Minister Ahod Ebrahim, and $\mathrm{Al} \mathrm{Haj}$, chairman of the Moro Islamic Liberation Front—whith both executive and legislative powers.

However, as much as BARMM is considered a major milestone towards peace and democratic transition in this historically restive region, it has several fundamental Bangsamoro Civil Society facilitated a workshop on ch strategic planning for political parties for various political polarization, patronage politics and clan wars civil society groups in Bangsamoro in support of the following almost half a century of conflict, and related BARMM transition in October 2019. The participants displacements and traumas. Additionally, BARMM is brainstormed on an action plan for establishing expected to hold its first parliamentary elections in 2022, regional political parties in Bangsamoro.

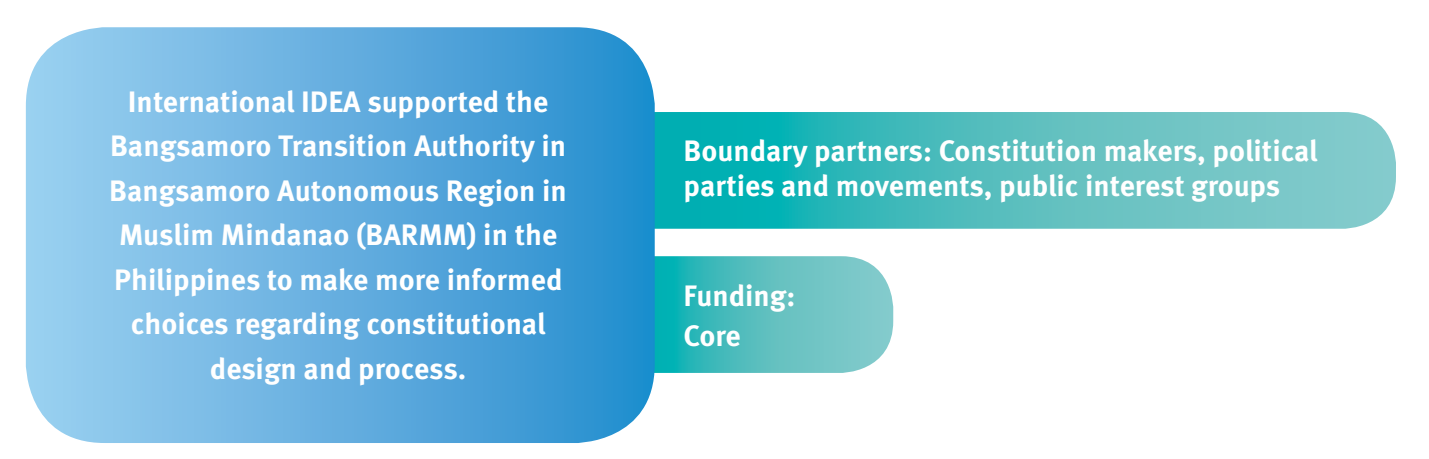

Upon consultation with representatives from the transition authority and other stakeholders, International IDEA found a niche to support the parliamentary ad hoc committees tasked to draft eight priority laws.

With the committees on electoral, administrative and indigenous peoples' affairs codes, the Institute has conducted various activities for members of the Bangsamoro Transition Authority, including an orientation workshop on drafting an electoral code. We have provided expertise on the challenges and opportunities associated with parliamentary systems, that informed the Administrative Code committee on the best fit for the BARMM, and have answered a request for review and advice on the draft Indigenous Peoples' Affairs Code.

We brought in Professor Cheryl Saunders, a senior advisor on constitution-building, and Hadar Gumay, former chairman of the Indonesian Election Commission, to provide in-depth information on elections, political parties, parliamentary systems and federalism.

Parallel to working with the transition authority, the Institute, in partnership with the Consortium of Bangsamoro Civil Society, facilitated a workshop for local CSOs on establishing political parties in the BARMM, using International IDEA's Strategic Planning for Political Parties: A Practical Tool.

Through this workshop, more than 50 participants discussed political party organization in post-conflict situations, understanding the challenges and opportunities for political parties and brainstorming action plans for part building in the BARMM.

This workshop has helped find answers to key questions of whether there is a need for political party building in BARMM, and what is the incentive for CSOs in supporting the formation and strengthening of regional political parties.

- Guiamel Alim, Chair of Consortium of Bangsamoro Civil Society.

As the transition has only just begun, International IDEA hopes to provide continued support to strengthen BARMM's democratic institutions and processes. 
CONSTITUTION-BUILDING PROCESSES

\section{Constitutional Review Commission of The Gambia leads constitutional review process with International IDEA assistance}

Supporting greater understanding of the new constitution and the constitutional review process

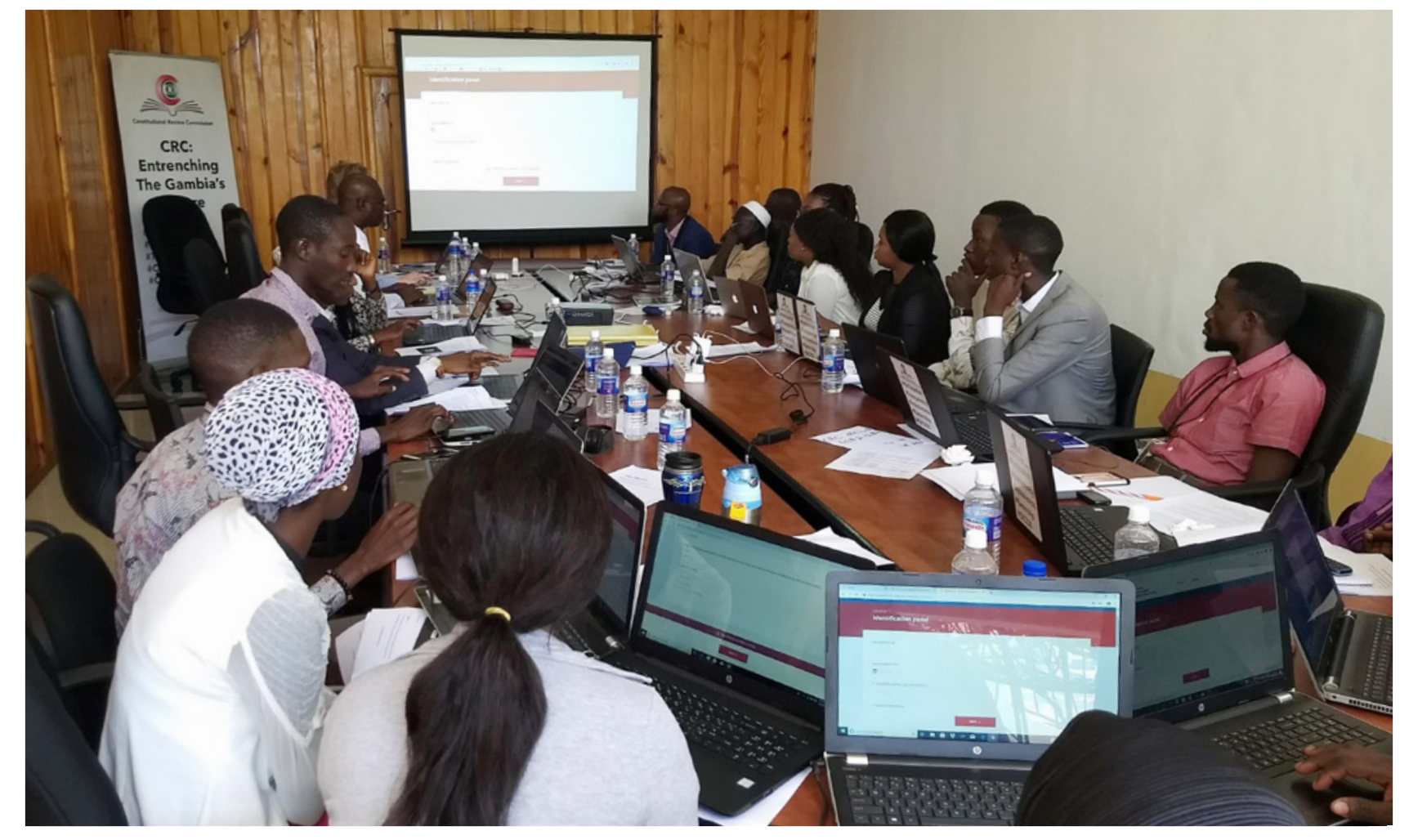

Staff of the Constitutional Review Commission of The Gambia discuss and review processes.

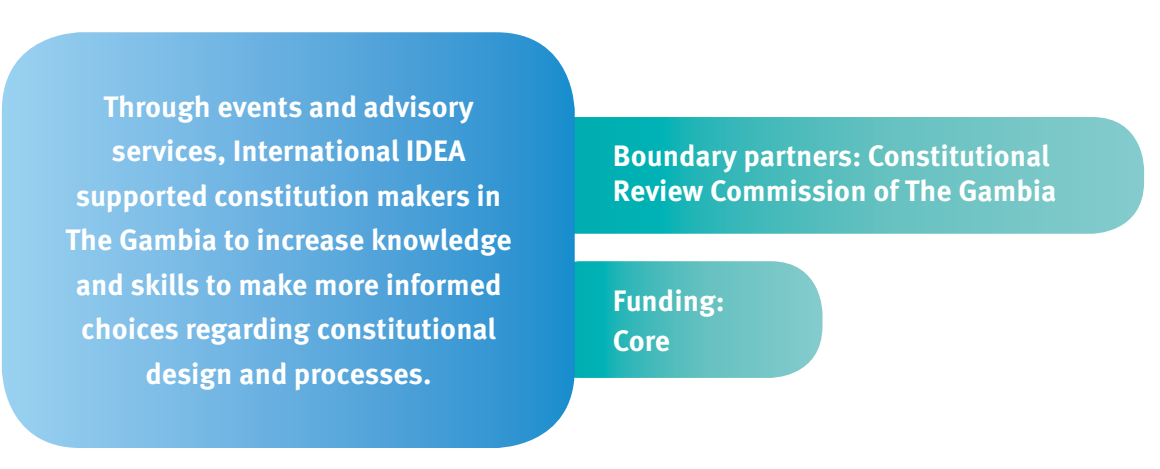

In 2018, at the request of Ministry of Justice in The Gambia, International IDEA's Constitution-Building programme began working with the newly established Constitutional Review Commission of The Gambia (CRC).

The main functions of the CRC were to review and analyse the 1997 Constitution, and to draft and write a report about a new constitution.

Through various events and advisory services International IDEA provided the CRC with guidance and helped develop an online public participation platform to support survey development, data management and data analysis as part of the CRC's public consultation activities.

In November 2019 the CRC released the highly anticipated draft constitution for public review and parliamentary scrutiny. The draft, if approved by referendum in 2020, will replace the 1997 Constitution, which was developed by the military dictatorship of former President Yahya Jammeh. The draft constitution includes a strengthened bil of rights, a more robust separation of powers, and special measures to increase the participation of women and youth.

At the launch of the draft constitution the CRC chair recognized the contribution of International IDEA: "We were able to benefit from the expert partnership and guidance of the International Institute for Democracy and Electoral Assistance, and I am proud to say that we continue to enjoy the partnership.'

Our Constitution-Building programme will continue to work with the CRC to strengthen the draft constitution, and has also begun supporting members of the National Assembly who will be tasked with reviewing, debating and voting on the draft in 2020 . 
CONSTITUTION-BUILDING

PROCESSES

\section{International IDEA supports constitution makers in Myanmar's Union Parliament}

Members of Parliament discuss constitutional reform, supported by International IDEA's trusted knowledge resources and workshops

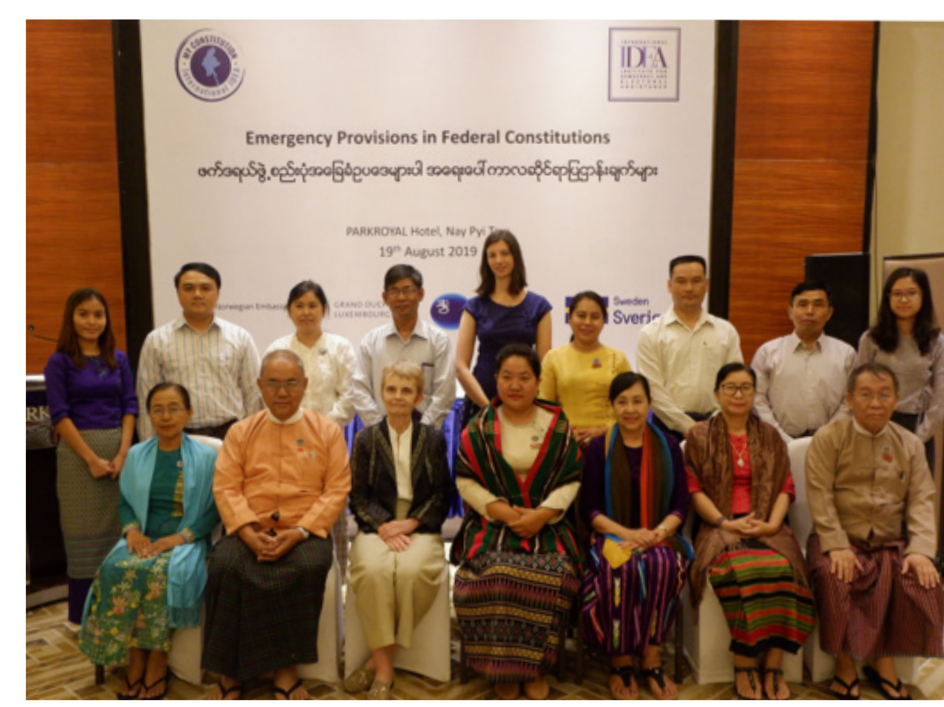

Myanmar's National League for Democrac government reinvigorated its election promise of constitutional reform, as Parliamen approved the formation of the Joint Parliamentary Committee on Constitutional Amendment (JPCCA) on 6 February 2019. This event caught pundits by surprise and returned the issue of amending the 2008 Constitution to the forefront of the country's political agenda.

Building on its expertise and previous work with the Union Parliament, International IDEA's MyConstitution programme has been taking the lead to provide trainings, events and knowledge products for this crucial

International IDEA's MyConstitution programme in Myanmar held several workshops on a variety of constitutional topics, including Emergency Provisions in Federal Constitutions. committee. The programme has organized seven workshops on a variety of constitutional topics. International IDEA also developed knowledge products based on requests from members of the JPCCA. Publications on the role of ministers in the legislature and the role of international law in constitutions are now available.

Although the constitutional amendment process still has a long and challenging road ahead, International IDEA's support to the JPCCA has already yielded rewards. For instance, relationships between the main stakeholders have been strengthened as all parties represented in the committee, including non-elected military representatives, attend and actively participate in our events, sharing their opinions and positions.

International IDEA is now able to facilitate discussions on sensitive constitutional questions with both ethnic political party and military representatives, which demonstrates their increasing trust in International IDEA as an institution and our non-prescriptive methodology. Members of parliament from various parties also frequently

Photo credit: International IDEA

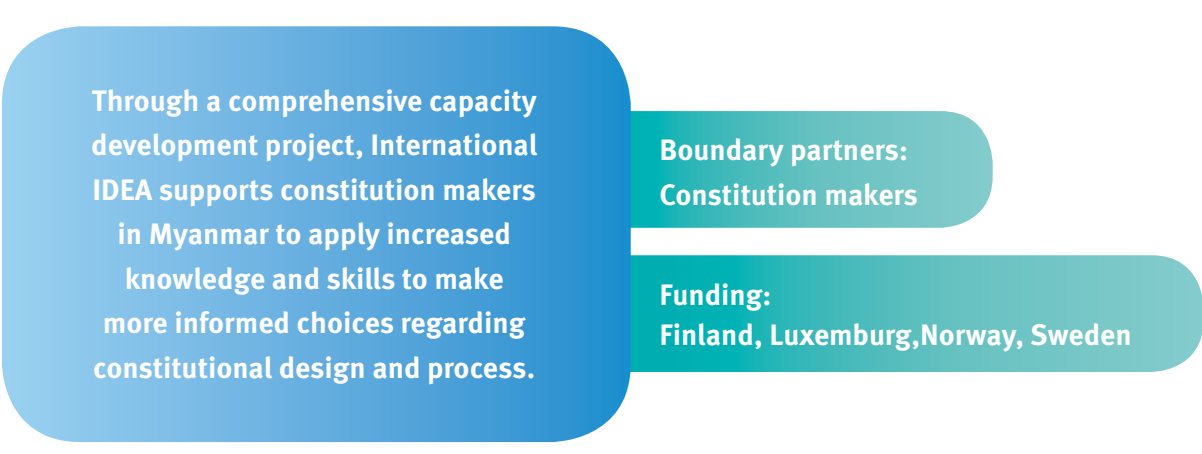

have specific requests on urgent topics that they wish to explore in more depth. These requests show that the MP are open to discussing new topics and exploring different constitutional solutions for Myanmar. They are eager to move beyond theoretical discussions to learn from specific case studies and ask critical questions that show that their knowledge of the issues discussed has increased considerably.

MPs recognize the utility of our support; they report that our workshops and knowledge products are useful, and that their understanding of the topics discussed has improved considerably. As a result, more and more MPs can draw on international best practice and engage in evidence-based discussions.

'It allows me to compare with other countries' experiences and to analyse possible consequences.

- Member of Parliament

MPs also noted they are more open to the idea of public participation. They asked International IDEA to organize a workshop on how independent branches and other institutions can be included in the constitutiondrafting process in a constructive manner. The workshops have also given them insights into the experiences and negotiation strategies of stakeholders involved in constitution-building processes in other conflict-affected and transitioning countries.

'It enables me to support the design and implementation of a democratic federal system in Myanmar [...] because it helped me to develop my capacity and wider knowledge. It helped me to engage in more and better discussion in the negotiations.'

- Member of Parliament

As the workshops are tailored to the MPs' specific needs, they found the lessons learned to be directly applicable to their discussions.

'The workshops are beneficial for our constitution amendment meetings. I will use [the lessons learned during our discussions in Hluttaw [parliament].'

- Member of Parliament 


\section{Yemen: Inclusive dialogues for peace}

International IDEA is an active and valued partner in the peace process

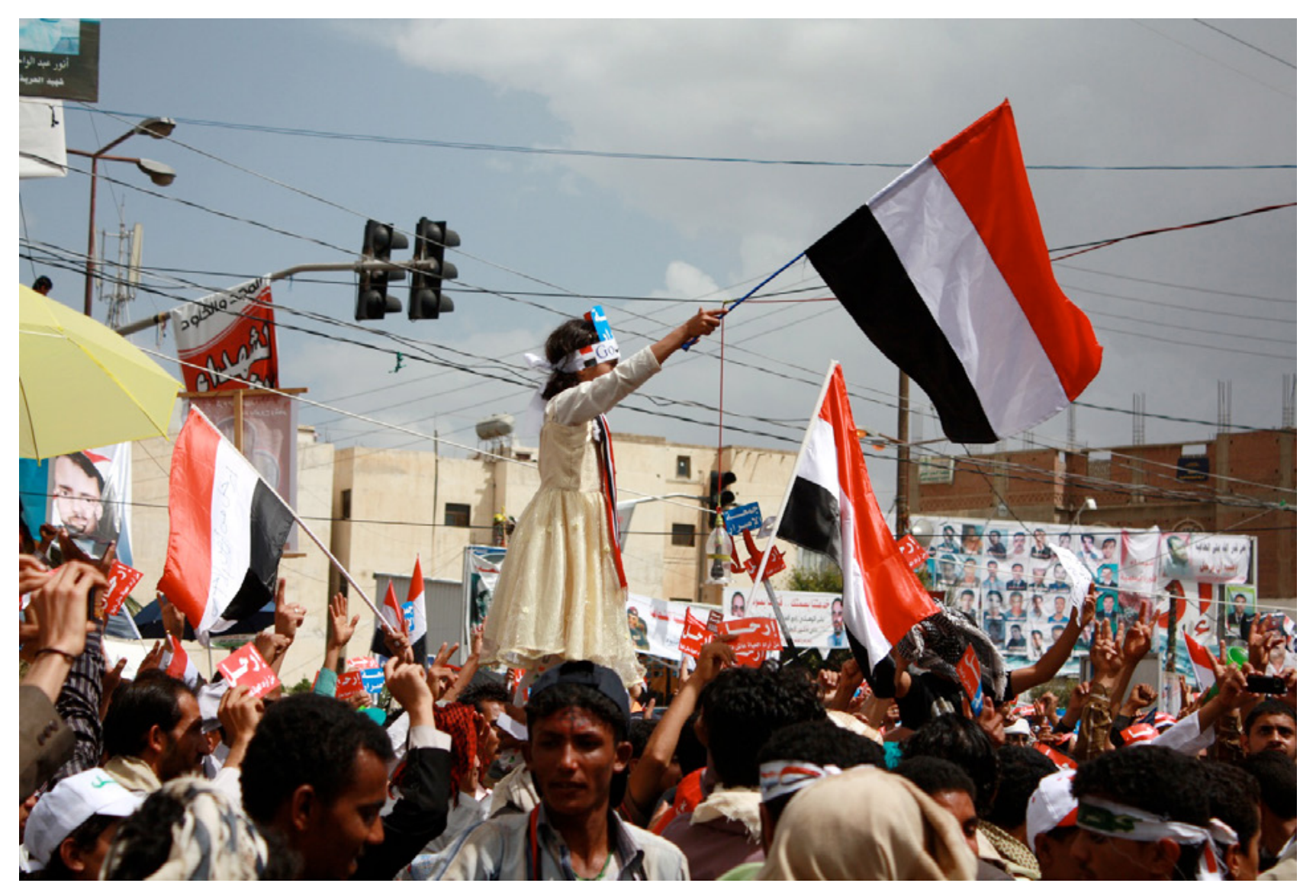

A girl holds the Yemeni flag during anti-regime protests in Sanaa

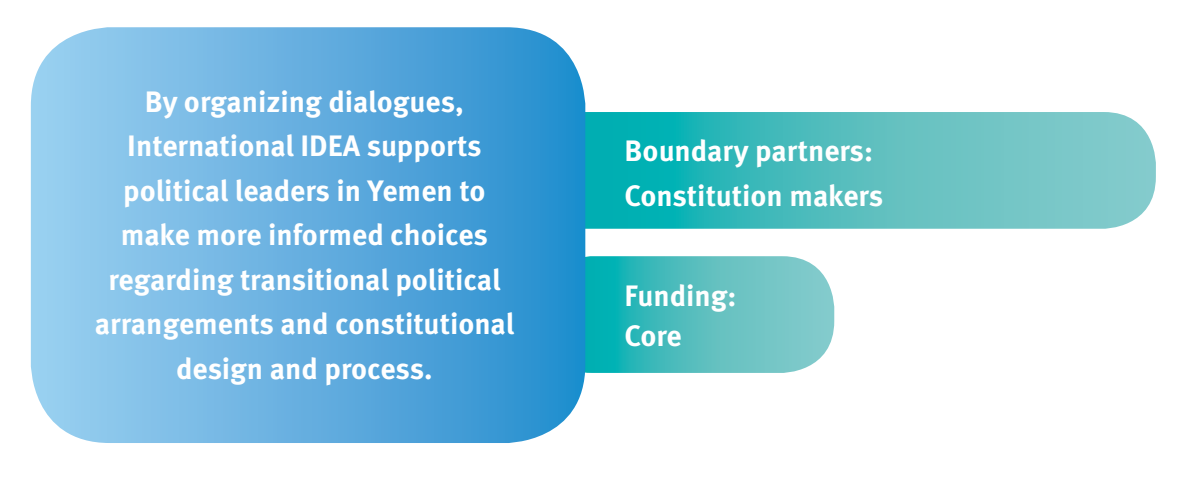

Since 2017, International IDEA has organized nearly 30 multiparty dialogue sessions, which have brought together leaders from Yemen's main political parties in non-committal discussions on the country's political future. These sessions seek to build a consensus on how transitional political arrangements should be designed and implemented, as well as the completion of the constitutional process, which was interrupted in 2015.

The UN Office of the Special Envoy of the Secretary-General for Yemen has applauded International IDEA for its contribution to the country's peace processes. In a briefing to the UN Security Council on 15 April 2019, the special envoy described the Institute as an 'active and valued partner' in the peace process and stated that it was 'centrally involved in the thinking and planning that we go through in this office'.

Yemen's situation is still highly precarious, and International IDEA remains committed to contributing to a sustainable solution to the conflict by enhancing its governance framework. The Institute's dialogue sessions remain the only setting in which both sides to the conflict continue to meet and engage with each other on how the country's future should be organized. These discussions have generated a clear understanding of how the postconflict transition may be organized and structured among the country's main political forces and key international actors 


\section{Outcome stories}

CONSTITUTION-BUILDING PROCESSES

\section{Supporting the federalization process in South Sudan}

Building public and political consensus for constitutional reform

\section{IDA}

Substate Constitutions in Fragile and Conflict-affected Settings

Under South Sudan's ongoing peace process, building agreement on the parameters of and mechanisms for federalization, along with transitional power scheme, is critical. In 2018, at the request of the minister of federal affairs, International IDEA's Constitution-building programme and the Africa and West Asia programme jointly supported the formation of a Working Group on Federalism (WGF). The WGF is the only national platform dedicated to discussing issues related to federalization and the peace process. It is tasked with proposing constitutional and institutional reforms for consideration by the Constitutional Review Commission, the public and the political decision-makers.

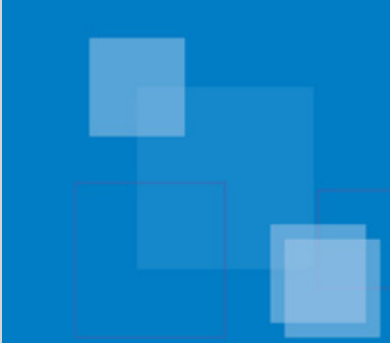

International IDEA facilitated the establishment of Federalism in South Sudan to increase constitution makers' knowledge and skilts to make more informed choices regardis constitutional design and processes.
In 2019, International IDEA continued to provide advisory services to the WGF under a project supported by the Government of the Netherlands. This support took the form of workshops held with WGF members, the provision of three options papers and facilitating discussions. As a direct outcome of these activities, the WGF identified and developed several consensus-based agreements for proposed constitutional reforms.

These agreements focus on sharing responsibilities and powers among states and central authorities, fiscal federalism, representation of states in national decision-making processes and ensuring that the composition of state institutions reflects the national character. Next steps for the WGF include building consensus on agreed proposals among the public, including those who oppose the federalization process.

Agreement on these issues is necessary to transform South Sudan into a fully fledged federation, as stipulated under the peace process. The WGF proposals are already setting the agenda for political and media discussion of the preconditions and implications of the transition to a federation. Coverage has been provided on South Sudanese television, radio and newspapers. 
CONSTITUTION-BUILDING PROCESSES

\section{Working on constitutional reform in Lebanon}

Reforming the constitution to better

resolve political crises through dialogue

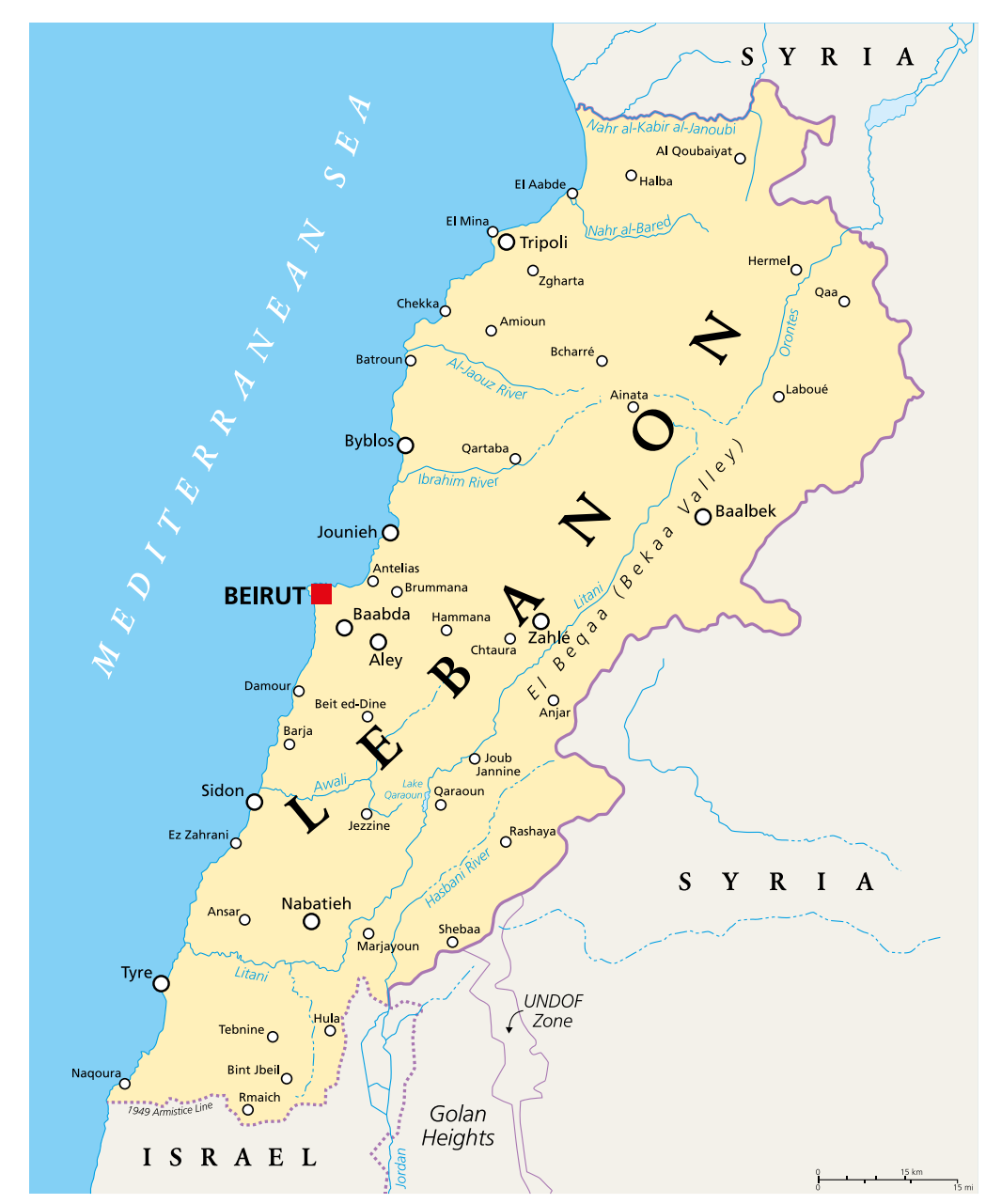

International IDEA has led a dialogue process on constitutional reform in Lebanon since 2017. In partnership with a leading Lebanese think tank and all the German political foundations that are present in Lebanon, International IDEA created a working group consisting of members of many of Lebanon's main political parties, leading activists and legal experts to support efforts to reform the country's constitution. The working group has met regularly for the past three years to discuss possible future improvement to the constitution.

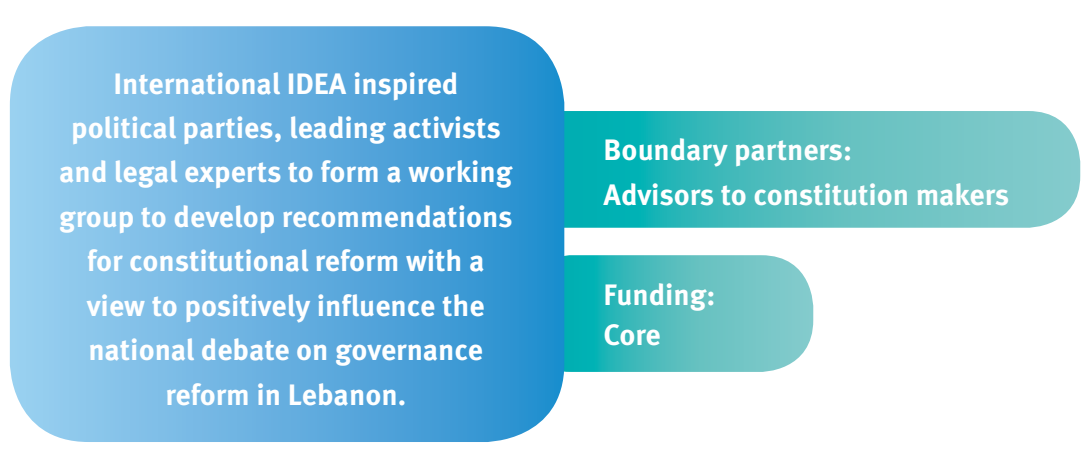

The project is motivated by an understanding that Lebanon's political crises were increasing in frequency and intensity, and that the constitution was not helping to resolve those crises.

In 2019, after three years of deliberation, the group agreed on a set of recommendations that were made public These recommendations have since been the focus of many debates across Lebanon, leading to an informed conversation about possible constitutional reforms.

The working group's deliberations represented the first meaningful and practical discussion of how to improve Lebanon's constitution after identifying the issues. In the context of the current uprising, International IDEA's project has shown that agreement on an improved system of governance is possible and within reach. Working group members are coordinating internally in order to positively influence the national debate on governance reform.
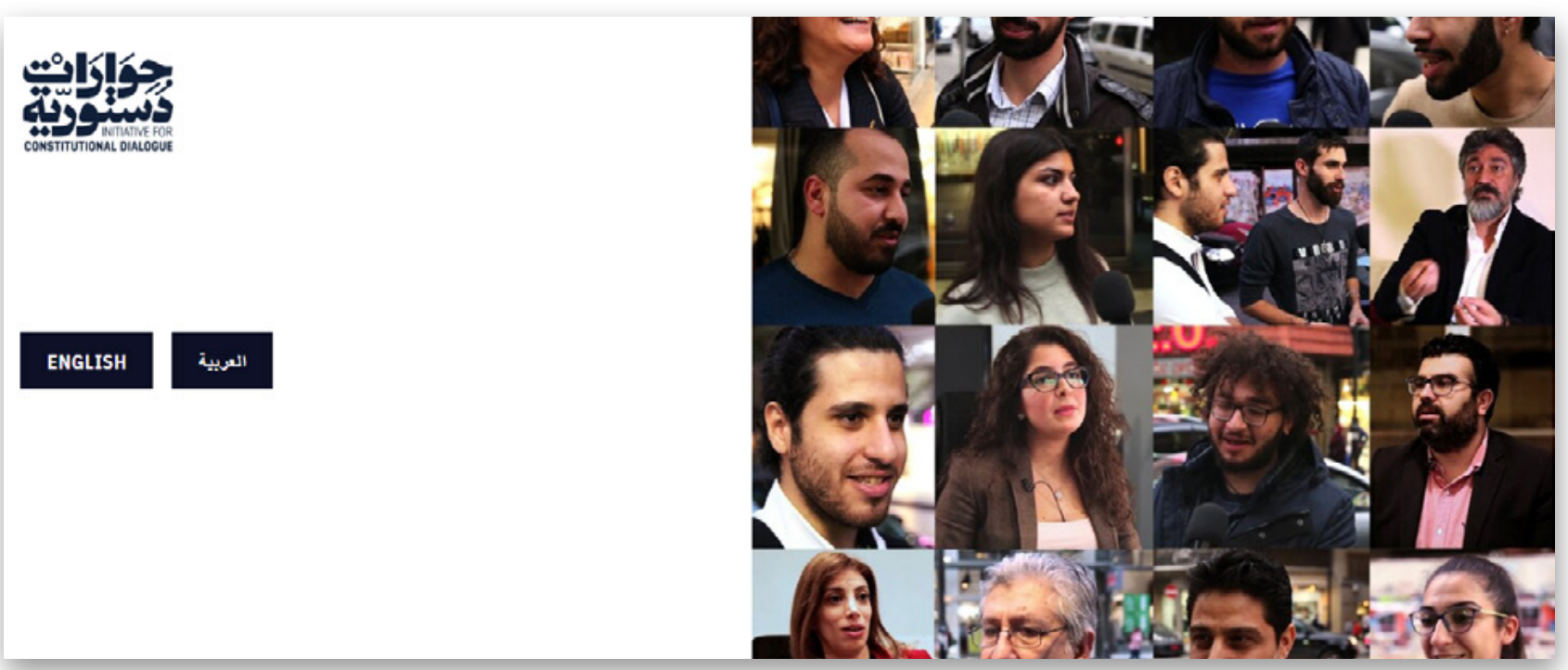
POLITICAL PARTICIPATION AND REPRESENTATION

\section{Mentoring elected local officials in Nepal}

Pilot project carves out space for deliberative local governance

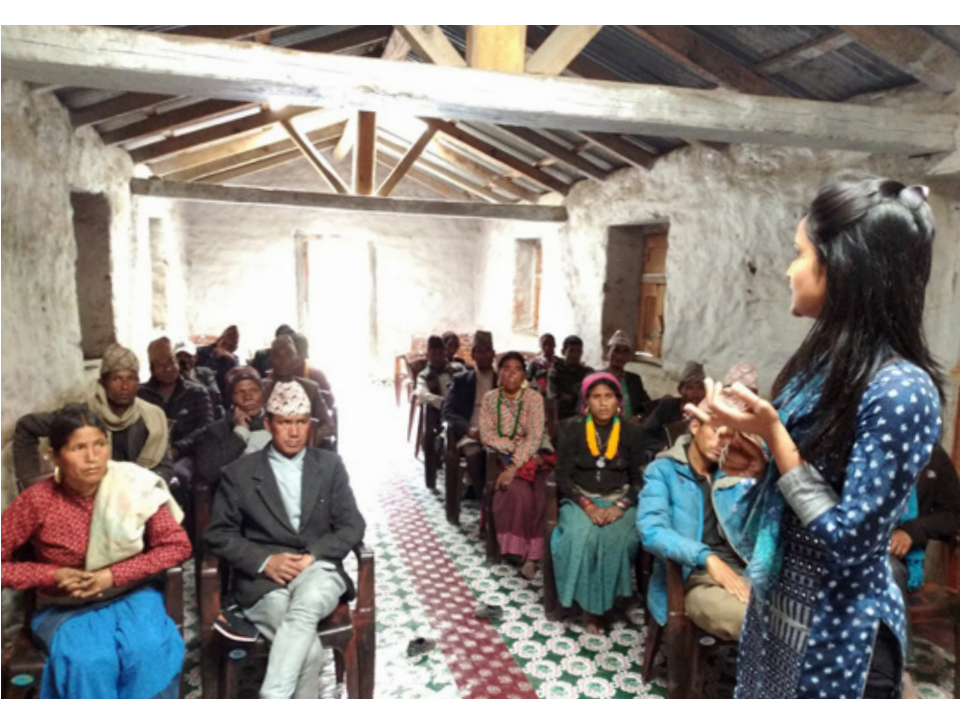

A mentor of International IDEA's Coherence programme explaining the elected representatives of a Adanchuli Gaunpalika (rural municipality) of Nepal's Karnali Province about the importance of their Gaunpalika's strategic vision in annual planning.

By testing a new approach providing a demand-driven programme using mentoring International IDEA supported local elected officials in Nepal from February to June 2019. The pilot programme was carrie out in six palikas (new municipal-type leve of government) of Karnali province. West Rukum, Salyan and Humla are the districts within this province, which are formed by the local government representatives. These units have coordinating roles within local governments.

By working in small teams, the mentors help the elected representatives establish systems and practices for local government. They work to support processes rather than projects or sectors, and are not a substitute for the work of the civil servants.

The pilot scheme is part of the Coherence Programme,' which has been working to build a common understanding of deliberative democratic local governance concepts and practice among federal, provincial and local stakeholders since 2017. The programme is a partnership between the Ministry of Federal Affairs and General Administration, International IDEA and DFID (United Kingdom’s Department for International Development).

The pilot ran from late February to early June, but despite the relatively short time, the results have been positive. Young graduate mentors are trained to act as 'change facilitators' or 'helping hands' to support the palika chair and elected representatives to reach collective decisions through both deliberation and consultation. The mentoring programme has been scaled up and a new partnership with Kathmandu University has been established.

Photo credit: International IDEA

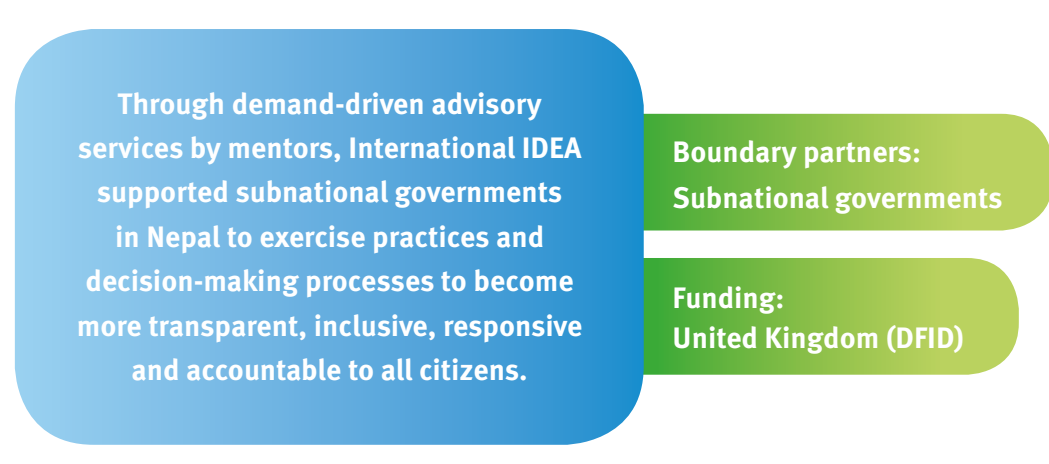

'Previously, we did not know what to do after the election. We managed somehow, but the mentors provided orientation to the process and steps, and we have found it to be an easy and efficient way to understand local governance processes.

- Local official involved in the pilo programme

Young graduates were selected as mentors in order to provide skilled graduates with opportunities to support the development of their country instead of seeking jobs abroad. Their fresh minds and new practices are unencumbered by the legacy of old ways of working

Starting off in only six palikas has allowed us to identify areas where the programme can be improved. For example, the mentor teams could have helped to reach all toles/settlements to facilitate consultations.

An independent team of reviewers recently visited Sanibheri, one of the six palikas, to evaluate the pilot and found that it had been successful and that it needed to be expanded and scaled up in the future.
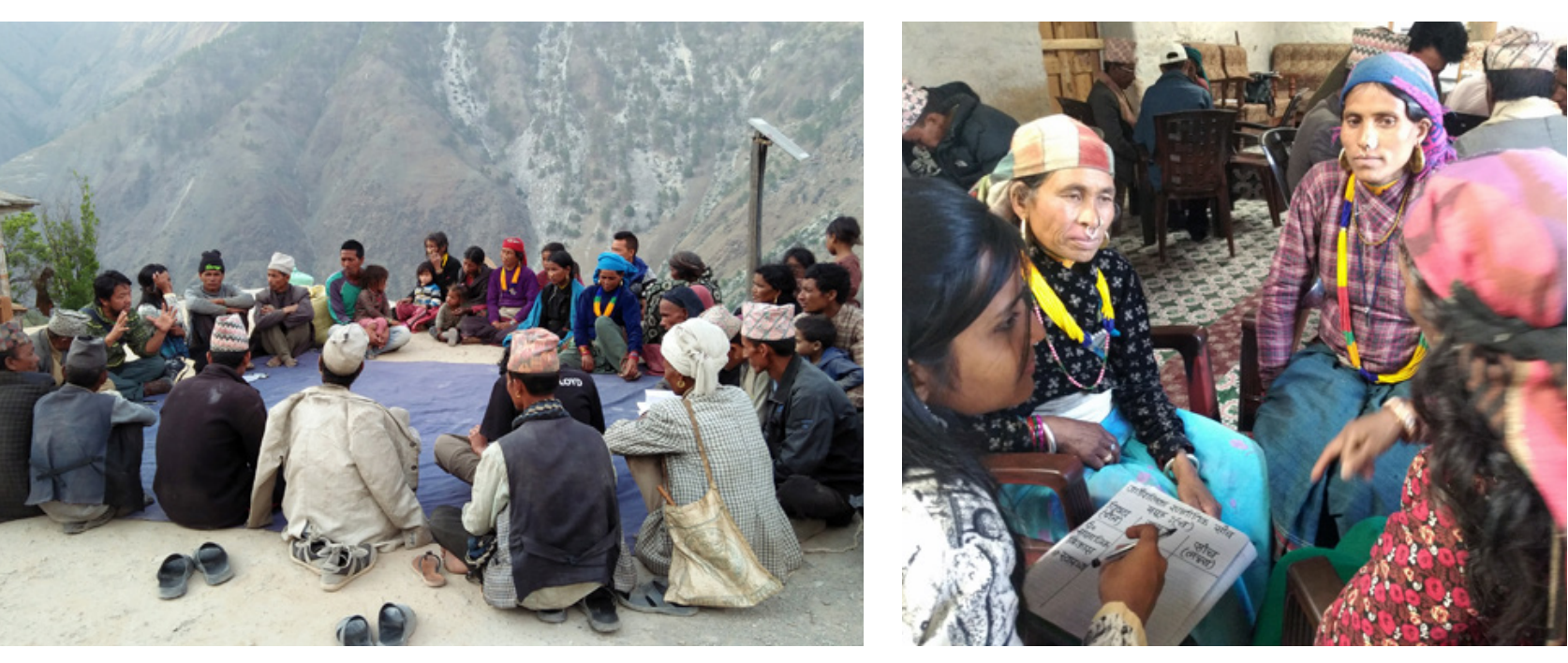

Left: Members of mentor team of International IDEA's 'Coherence Programme' explaining to the elected representatives of Adanchuli Gaunpalika (rural municipality) of Nepal's Karnali Province the steps of preparing an effective annual plan and budget for their Gaunpalika

Right: A mentor from International IDEA's 'Coherence Programme' helping the elected women representatives of a Gaunpalika (local government) in a remote district of Humla (rural municipality) in Nepal's Karnali Province in a role play to draft a strategic vision for their Gaunpalik. 
POLITICAL PARTICIPATION

AND REPRESENTATION

\section{International IDEA looks to regional governance in Bolivia to bolster development}

Multi-level technical assistance in governance builds bridges between Cochabamba's regional and municipal authorities

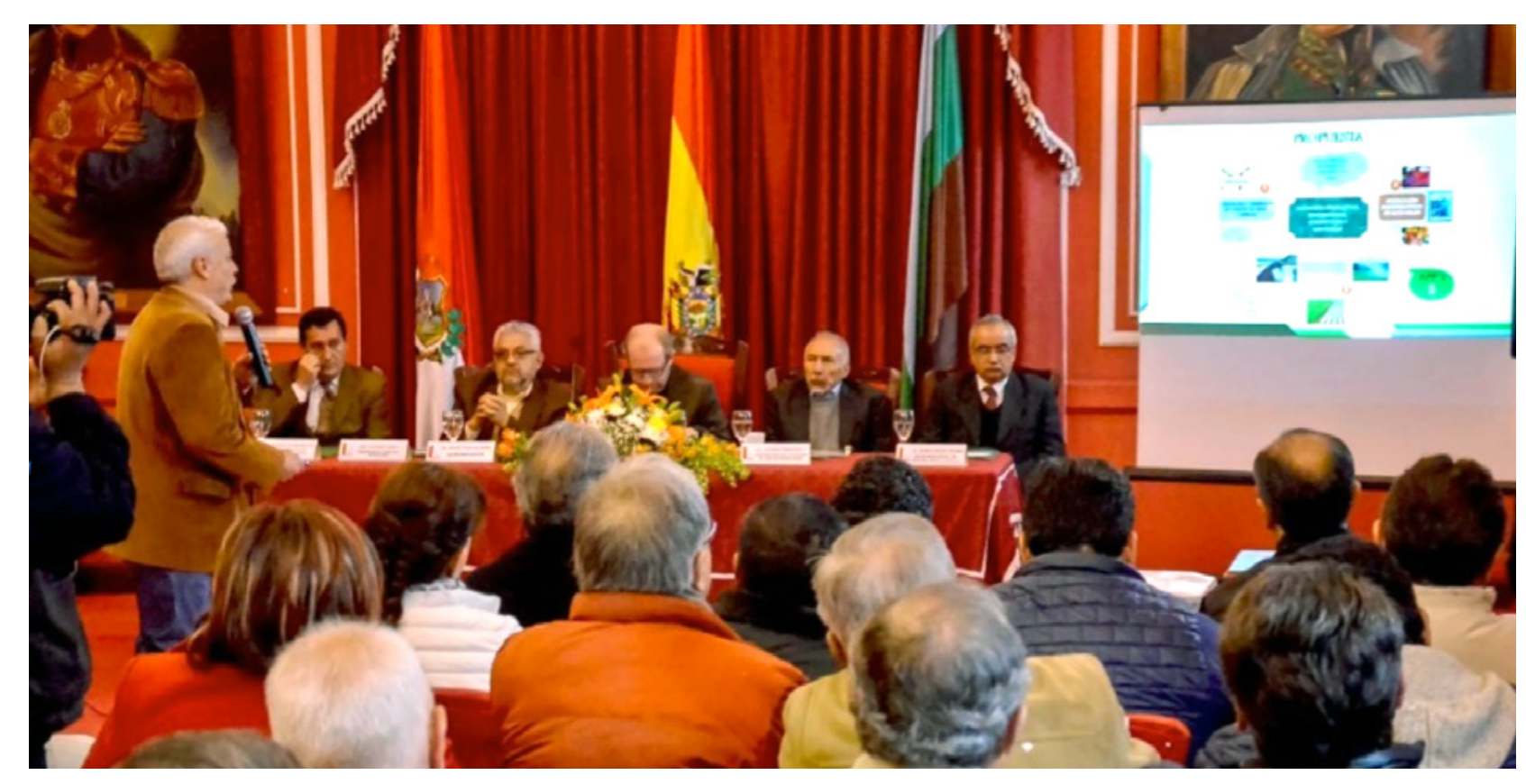

Panelists and attendees discussing development in Tarija, in the presence of the governor.

International IDEA has provided technical advice to enable the autonomous regions of Tarija and Cochabamba to carve out new horizons in their development—a life beyond natural gas inTarija, and launching a set of longawaited projects in Cochabamba's metropolitan areas.

Tarija's governorship presented a Production Diversity Programme to promote the region's development, an innovative initiative which proposes a new development model, centred around water as a resource, leaving behind the history of over-reliance on natural gas.

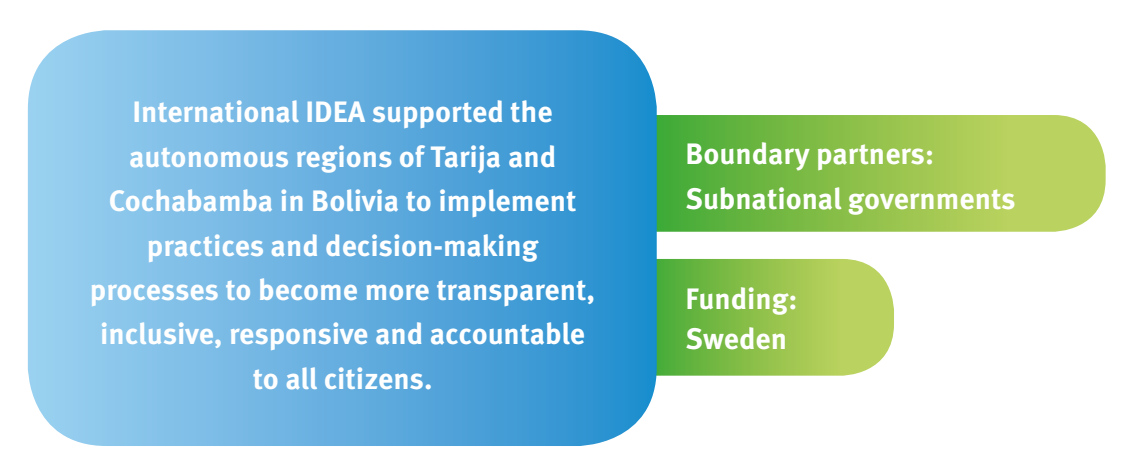

The programme document was prepared by the governorship, through the Institutional Governance Secretariat, the Comprehensive Regional Governance Water Services, the Regional Agricultural Services, the Land Restoration Executive Program and the San Jacinto Multilayered Program, with assistance from International IDEA and Fundación Natura.

For Alfonso Ferrufino, International IDEA's senior adviser in Bolivia, this represents 'a light at the end of the tunnel' as the programme opens new horizons for the development of Tarija. 'Through the many inquiries which we have undertaken since 2017 we had observed that a sense of vision had gone missing. What had come about following the fall of revenues stemming from hydrocarbons not only stripped away a development horizon, but also brought about an atmosphere of mistrust and a loss of social cohesion, and it seemed as though Tarija would drift away', he explained.

Tarija's institutional governance secretary, Rubén Ardava, explains that 'the focus of the current development model lies in that we are preparing the Autonomous Region of Tarija for the struggle against climate change. We are working to equip our autonomous region as to the significance of its development model over the next 20 years'.

Regarding Cochabamba, the teamwork effort undertaken on a regular basis between the governor and the seven mayors of the city's municipalities has been instituted, with the aim of tackling the main metropolitan challenges. Among International IDEA's most important contributions are the regulations encompassed in the law, Marco de Autonomías, which develops a planning and governance mechanism for the metropolitan areas through Metropolitan Council. Likewise, International IDEA also provided advice on the development of the monitoring system for strategic projects, which are the main outputs arising from metropolitan planning and execution. The Metropolitan Council is a model of joint governance between autonomous authorities from different jurisdictions and political orientations that is both democratic and pluralistic 


\section{Training for increased women's political participation in Myanmar}

Creating women's wings within political parties allows women greater influence over policymaking

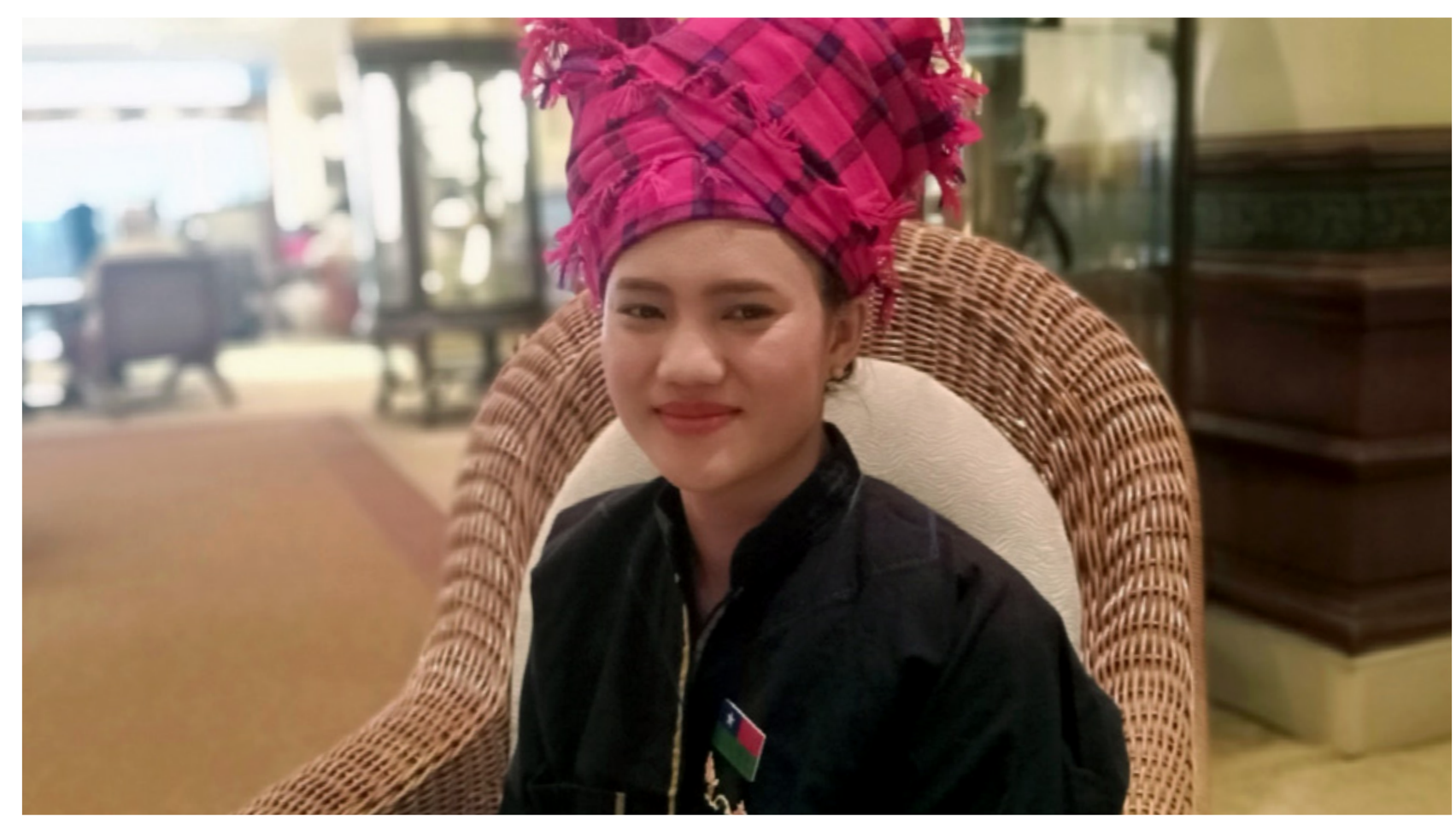

Nang Tin Shwe 0o, member of Myanmar’s Pa’O National Organization.

Nang Tin Shwe Oo is a member of the $\mathrm{Pa}^{\prime} \mathrm{O}$ National Organization (PNO), an ethnic political party from the Pa'O region in Myanmar's Shan State. The PNO is one of 41 political parties in the country that has created a women's wing with support and training through the European Union-funded 'Support to Electoral Processes and Democracy (STEP Democracy)' programme in Myanmar.
The European Union-funded Support to Electoral Processes and Democracy (STEP

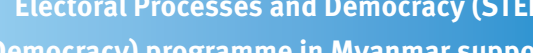
political parties to establish and maintain romen and youth wings that strengthen the party system and make it more inclusive, responsive and accountable to all citizens.
Boundary partners:

Political parties and movements

Funding: Funding:
European Union

The STEP Democracy programme is managed by International IDEA and currently implemented by five international organizations and three local organizations. The programme supports inclusive, peaceful and credible electoral processes, and enhances the capacity of stakeholders to strengthen the democratic transition in Myanmar. It is an integrated programme closely coordinated with national stakeholders—-with the Union Election Commission, political parties, media organizations and civil society organizations involved in domestic election observation, voter and civic education, and advocacy for reform. The support to women and youth wings within political parties is implemented by the Danish Institute for Parties and Democracy and aims to strengthen the party system in Myanmar and make it more inclusive, responsive and accountable to all citizens.

The establishment of women's wings is an important first step to empower female party members, such as Nang Tin Shwe Oo, to make their voices heard and influence policymaking within their parties. STEP Democracy supports the women's wings in this endeavour: women members of the PNO have received training in the technical skills needed to take a more active role in party activities, decision-making and internal electoral processes. The programme has also provided trainings designed to develop women's skills for campaigning, campaign management, communication, public speaking and advocacy. These trainings have been complemented by dialogue activities between women leaders and party leaders on practical ways to increase women's political participation. Moreover the programme has produced two tools:

- Better in Politics: A Female Politician's Guide towards Knowledge and Empowerment aims to help female politicians understand the important elements of politics and gain greater confidence in their work

- Guidelines for Political Parties in Myanmar Gender Equality: A Shortcut to Development and Prosperity which contains practical steps for parties to enhance gender equality within their structures, policies and culture.

The programme is in its second year, and Nang Tin Shwe Oo says that its supportive activities have been vital in her work to empower women and raise gender awareness in Shan State. 


\section{Promoting the responsible use of social networks and regulating political financing in Argentina}

A Digital Ethical Commitment was the result of a collective effort to improve public information sharing

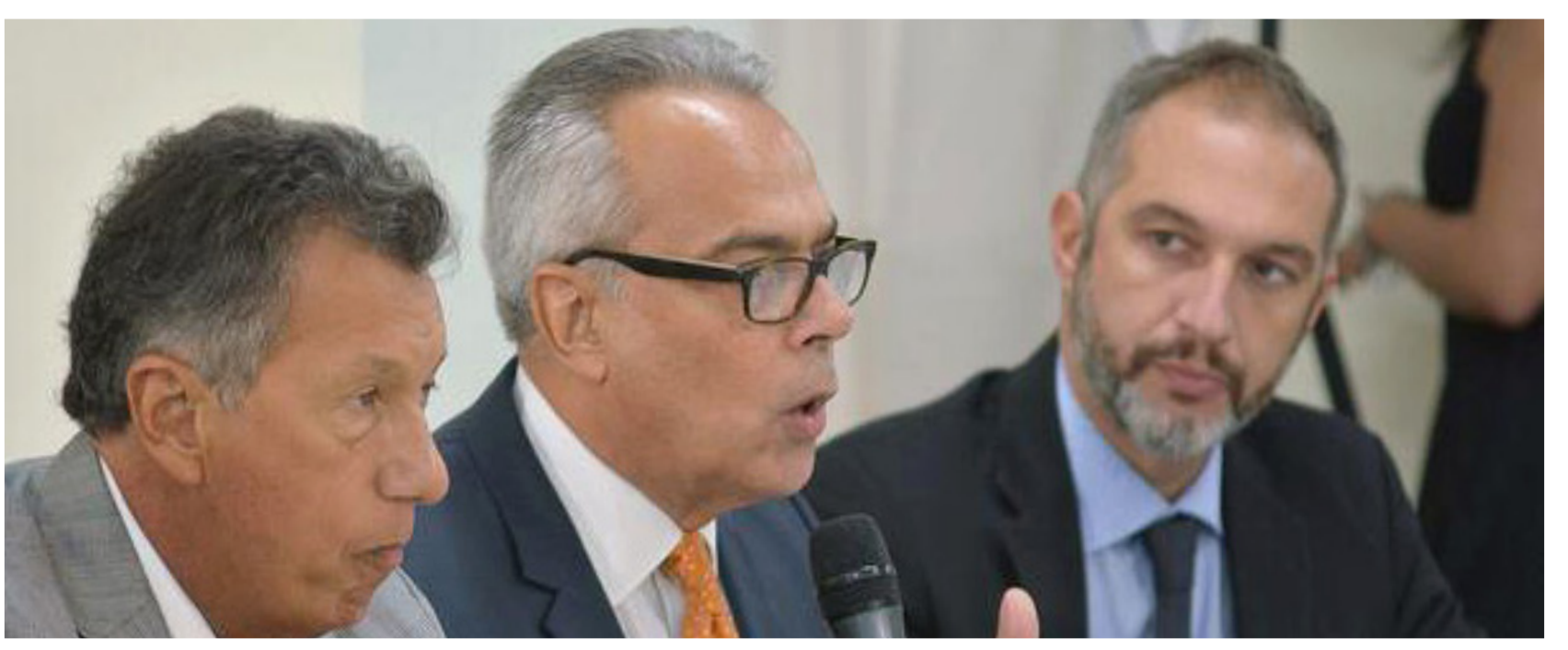

Daniel Zovatto, International IDEA's Regional Director for the Latin America and the Caribbean, speaks about the risk of social media misuse.

As Argentina prepared for the October 2019 elections, it faced multiple challenges. One of these challenges was to develop an effective strategy to allow electoral authorities to confront the misuse of social networks during electoral campaigns. Another was to pass a new law on political finance in the National Congress, which would allow for greater transparency, control and accountability.

International IDEA's Latin America and the Caribbean programme has worked with the National Electoral Chamber (CNE), the Wilson Center, the Annenberg Foundation and the Argentine Council for International Relations to support the Argentine government in addressing these challenges. The work contributed to the signing of the Digital Ethical Commitment in May 2019, which is an agreement between the CNE; political parties; social media platforms (including Google, Twitter, Facebook and WhatsApp); the Association of Journalistic Entities;

Photo credit: Argentine Council for International Relations

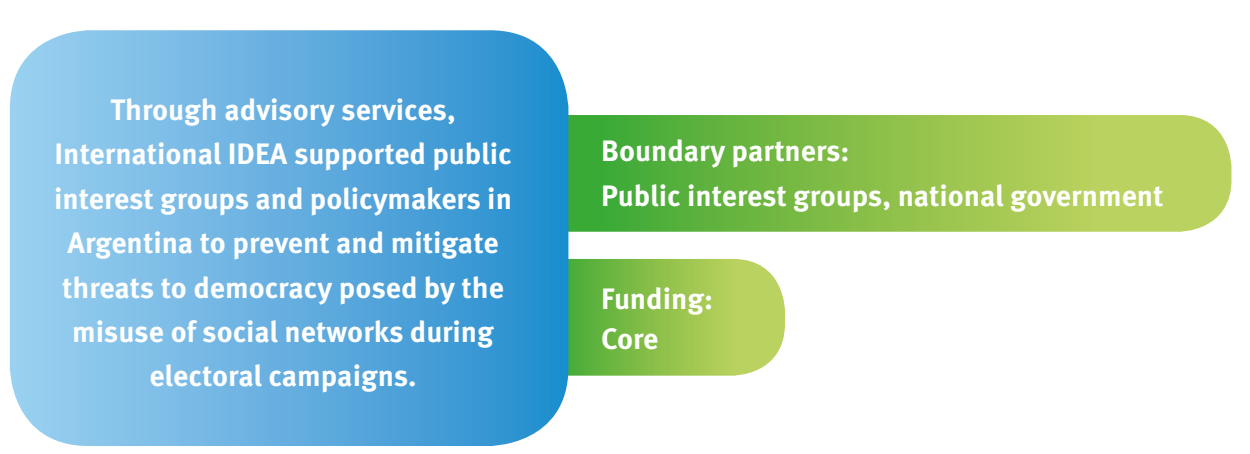

the Latin American Internet Association; and the Association of Digital Journalism to follow common ethica guidelines when using social media, and to prevent the spread of fake news.

This Digital Ethical Commitment allowed the CNE to sign bilateral agreements with large social media and internet companies:

Twitter agreed to facilitate the live transmission of the three presidential debates and advised the CNE on how to create a bot that would allow Twitter to share key electoral information.

- Facebook sent a reminder to vote on election day to users over the age of 16 and created an 'informed voter' button to redirect users to an external CNE website where they could find relevant information.

- Google allowed the transmission of the presidential election debates through its YouTube platform.

The valuable support that the regional programme of International IDEA provided to the CNE in the field of social networks helped us to successfully implement the ideas that inspired the signing of the Digita Ethical Commitment. In particular, it allowed us to learn from the experiences of the Electoral Tribunal of Panama in the areas of social network monitoring, campaign expenses in the digital environment and the propagation of fake news. The support of International IDEA contributed greatly to strengthen the powers of the CNE in this new area.

- Hernán Goncalves, Secretary of Judicial Performance, National Electoral Chamber of Argentina

International IDEA provides ongoing advisory services to the Ministry of Interior and the CNE to reform the political financing system. This assistance helped promote a new law on political financing, which was approved in the National Congress on 15 May 2019.

One of the most relevant aspects of this new law is that it allows companies to donate money to electoral campaigns, provided these contributions do not exceed 2 per cent of the total campaign expenses. Furthermore, the law requires that donors must be identified on the $\mathrm{CNE}$ website, and all contributions must be made exclusively through the formal banking system. 


\section{Strengthening women's political participation in Bhutan}

Identifying obstacles and focusing on long-term

solutions to propose strategies for equal representation

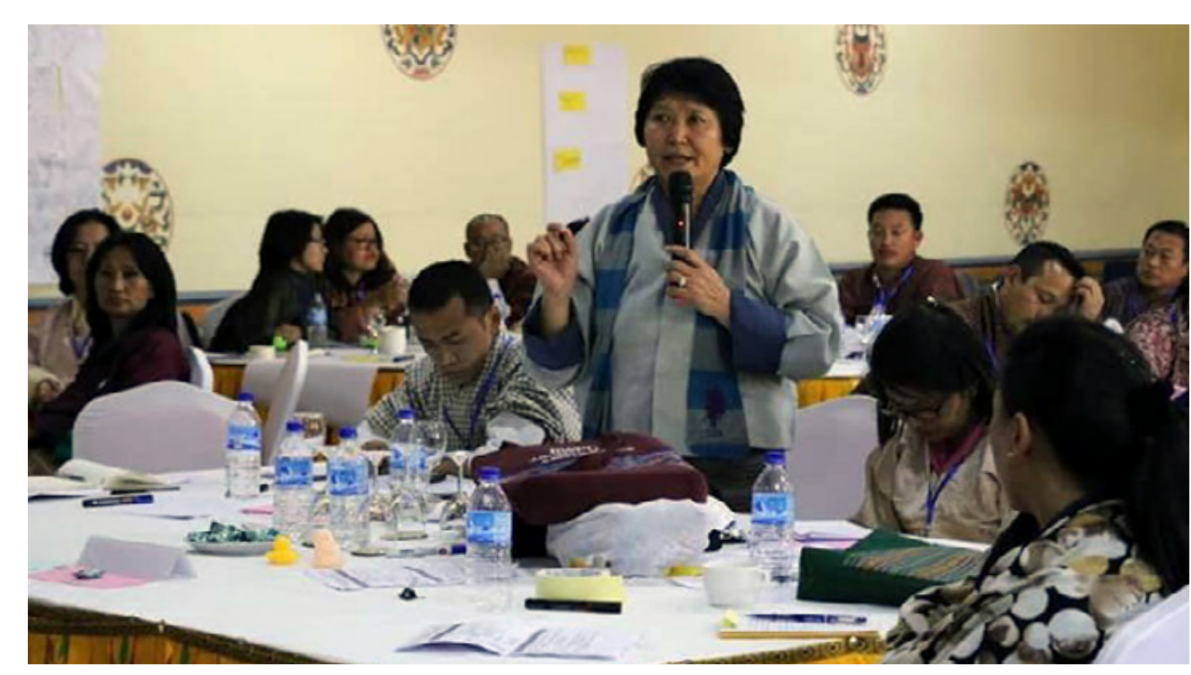

Former minister Dasho Dori Choden, the first female minister, addresses the challenges Bhutanese women politicians face before her fellow participants during the Bhutan Women Parliamentary Caucus orientation wor held in Paro in November 2019

The number of women elected to Parliament in Bhutan increased from 8.3 per cent in the 2013 election to 15.2 per cent in 2018 - the highest percentage of women in Parliament in the country's history. International IDEA is building on this momentum to continue its work in the country to support women in politics. In August 2019, International IDEA provided support to the Bhutan Network of Empowering Women (BNEW) and the National Commission for Women and Children from the Bhutan Women Parliamentary Caucus (BWPC).

The BWPC provides a platform for women parliamentarians and future candidates to collaborate with relevan stakeholders to promote the vision of an inclusive democracy in Bhutan. The first BWPC orientation workshop, with a theme of 'Towards Common Understanding and Strategizing for Gender Equality in Bhutan', was cofunded by International IDEA, the Danish Institute for Parties and Democracy and the UNDP.

One major outcome of the project was the launch of the BWPC itself. It is historic that BNEW strategized and managed to make the caucus a reality within the project duration as aspired, given the prevailing mindsets and challenges in advancing the gender agenda in Bhutan.

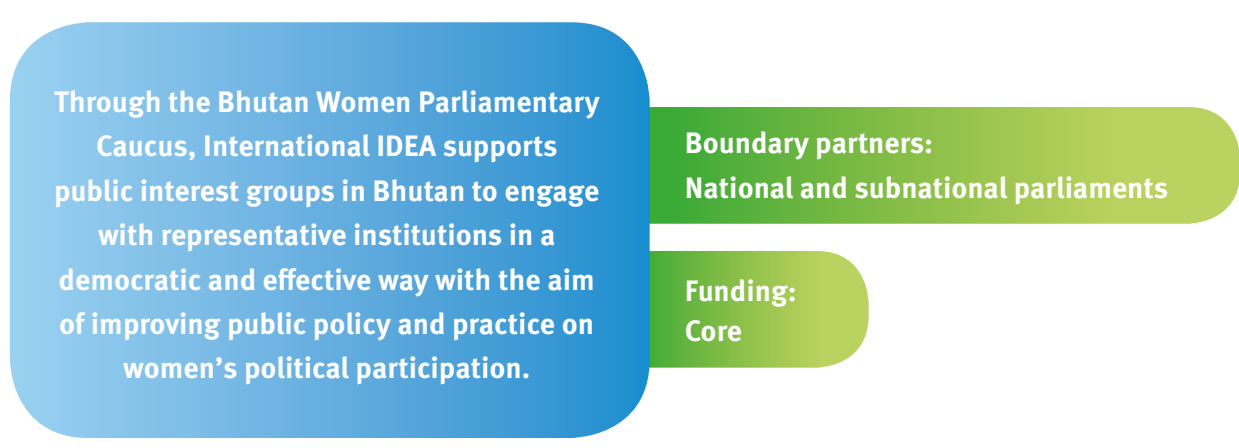

As a result of the leadership training and workshop for the BWPC members (including male Members of Parliament), the first-time serving women MPs as well as male MPs found the space useful for networking and enhanced their knowledge and confidence. Moreover, the MPs also cited that the forum has effectively led to enriching discussion and building consensus on advocating gender-sensitive legislation.

The BWPC members are using the platform to effectively strategize and promote gender policy agenda prior to the Parliament sessions.

'As a visible result of the capacity building and exposure provided through this project, we observed more heightened and confident voices of women parliamentarians during recent session of the Parliament in February to March 2020', said Phuntshok Choden, executive director of the Bhutan Network of Empowering Women. 'We noted an unprecedented gender sensitivity among male Parliamentarians too who were seen supporting positions (to enhance representation of women in Parliament) proposed by female colleagues.'

Overall, we saw a greater and active participation by women MPs in recent sessions, which can be indirectly attributed to the various inputs provided by BNEW to BWPC members.

Over the past three years, International IDEA has supported BNEW's work to promote gender equality in the media, political parties, CSOs and various government institutions. While these efforts have led to positive change of behaviours and relationships, Bhutan is still below both the global average of 22 per cent women in parliament and the regional average of 19.6 per cent.

'There is a strong and continued need to create awareness on gender biases, stereotypes, norms and attitudes which are deeply entrenched in the society. Prevalent norms which maintain inequality in elections and political leadership have to be corrected.

- Phuntshok Choden, executive director, Bhutan Network of Empowering Women 


\section{Developing a Code of Conduct for elections in Moldova}

Protecting the integrity of electoral campaign financing

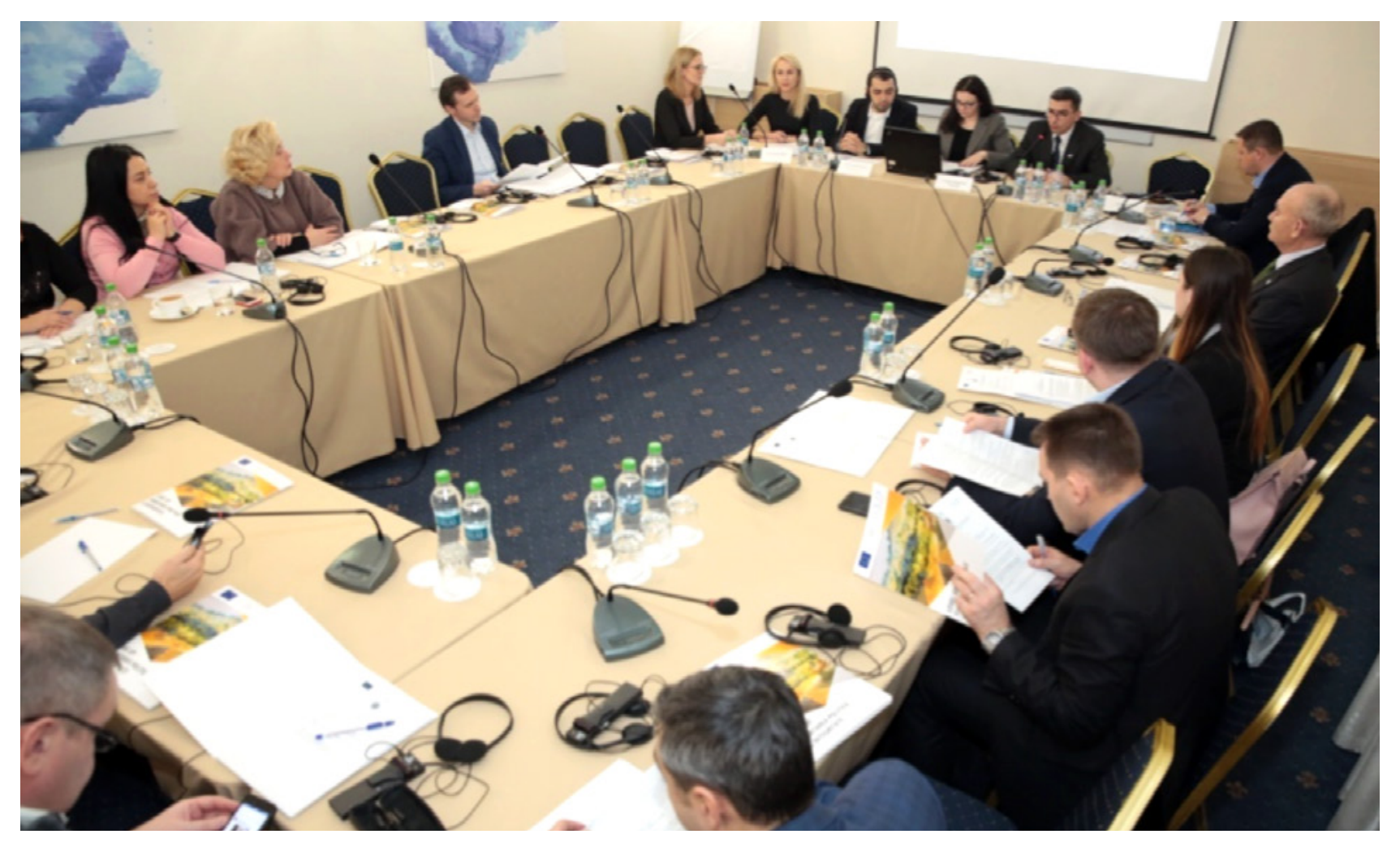

International IDEA hosts an interparty roundtable to develop a common Code of Conduct to protect the integrity of electoral campaign financing, together with the Moldovan Electoral Commission and the Centre for Continuous Electoral Training.

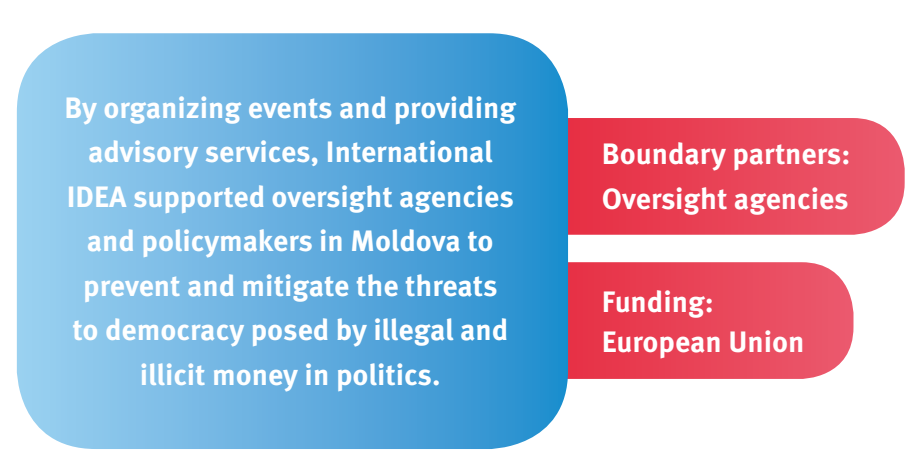

The European Union-funded 'Level Up: Political Finance with Integrity' project is implemented by International IDEA in partnership with the Moldovan Centre for Continuous Electoral Training (CICDE). The project supports reforms in political and campaign finance in Moldova by providing advisory services related to reforming the country's political finance system and its practical enforcement.

While the project coincided with increased political polarization and instability in the country, it brought rival political parties together to discuss regulatory and practical solutions to harmful practices. For example, International IDEA hosted an interparty event to develop a common Code of Conduct to protect the integrity of electoral campaign financing, together with the Moldovan Electoral Commission and the CICDE.

After the event, International IDEA supported the development of the text of the Code of Conduct to address these practices ahead of the parliamentary elections held in February 2019. The Central Electoral Commission (CEC) opened the Code of Conduct for signature in January 2019. It ensured wide media and public circulation of its call for all electoral contestants to sign the code and uphold its principles in the upcoming elections.

While the use of illicit funds and indirect forms of vote buying are deeply rooted problems in Moldova, the process of engaging parties from across the political spectrum and putting a high-level focus on the issue of thirdparty financing, for the first time in the country's history, yielded incremental but important outcomes.

Political parties showed more confidence in using official channels of legal recourse, as several complaints were lodged with the CEC during the ensuing campaion. The CEC in turn demonstrated a higher level of awarenes of and expedience in addressing these appeals. Also, as some observers noted, the process positively influenced the electoral campaign since all contestants committed to uphold the integrity of their campaign finances and demonstrated a higher degree of self-restraint 
POLITICAL PARTICIPATION AND REPRESENTATION

\section{Supporting women candidates for parliamentary elections in Tunisia}

Removing the remaining barriers to women's political participation through trainings in media relations, electoral management and strategic planning

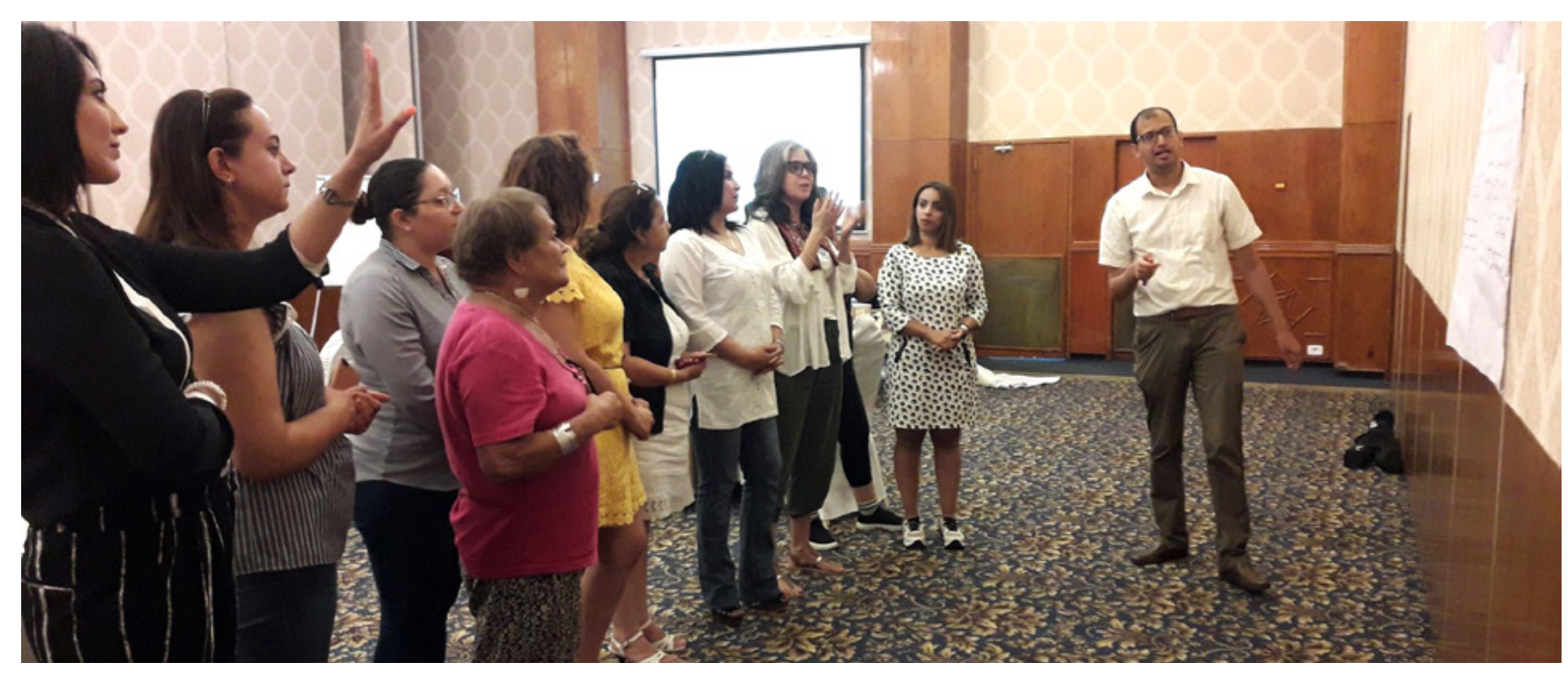

Campaign management training for women candidates in the 2019 Tunisian parliamentary elections.

At 36 per cent, Tunisia has the highest proportion of female representatives in parliament in the Arab world and ranks 30th among the world's democracies. Despite great success in achieving greater representation for Tunisian women in politics, many women report challenges associated with taking part in all aspects of political life.

Leading up to the 2019 parliamentary elections, International IDEA organized a series of workshops to facilitate earning about these challenges. Candidates running for parliamentary elections noted that women still struggled to reach the leadership level within their political parties, and said they are often excluded from strategic discussions. Many also have inadequate financial and human resources for their work and said that their poor knowledge of internal processes made it more difficult for them to influence party policies.
In response to these issues, and to prepare women candidates ahead of the 2019 parliamentary elections, International IDEA organized trainings for women candidates focusing on three key areas-media relations and public speaking, electoral campaign management, and strategic planning. We contacted several political parties asking them to nominate women candidates to participate in these trainings and nine parties sent their nominations for 22 women who attended at least one of three trainings.

'Citizens don't care about the candidate's sex. They care only about what he/she can achieve for them.' - Haifa Ben Fraj, one of the participants and head of the candidate list of Al-Qotb in the constituency of Kairouan

The trainings enhanced the candidates' understanding of the electoral process, improving their ability to run successful campaigns, and allowed them to share experiences.

Three of these participants were successfully elected for the first time to parliament in the elections of 6 October 2019. Two of the elected women, Kenza Ajala and Marwa Ben Tamrout, are from the Ennahdha Movement political party, and secured seats for the Gabes and Medenine constituencies, respectively. The third elected membe is Sonia Khechine from the Tahya Tounes political party, who secured the seat for the Ben Arous constituency. 


\section{CANDI Dat@s: a stake on informed voting}

Web tool engages young voters in Bolivia's elections

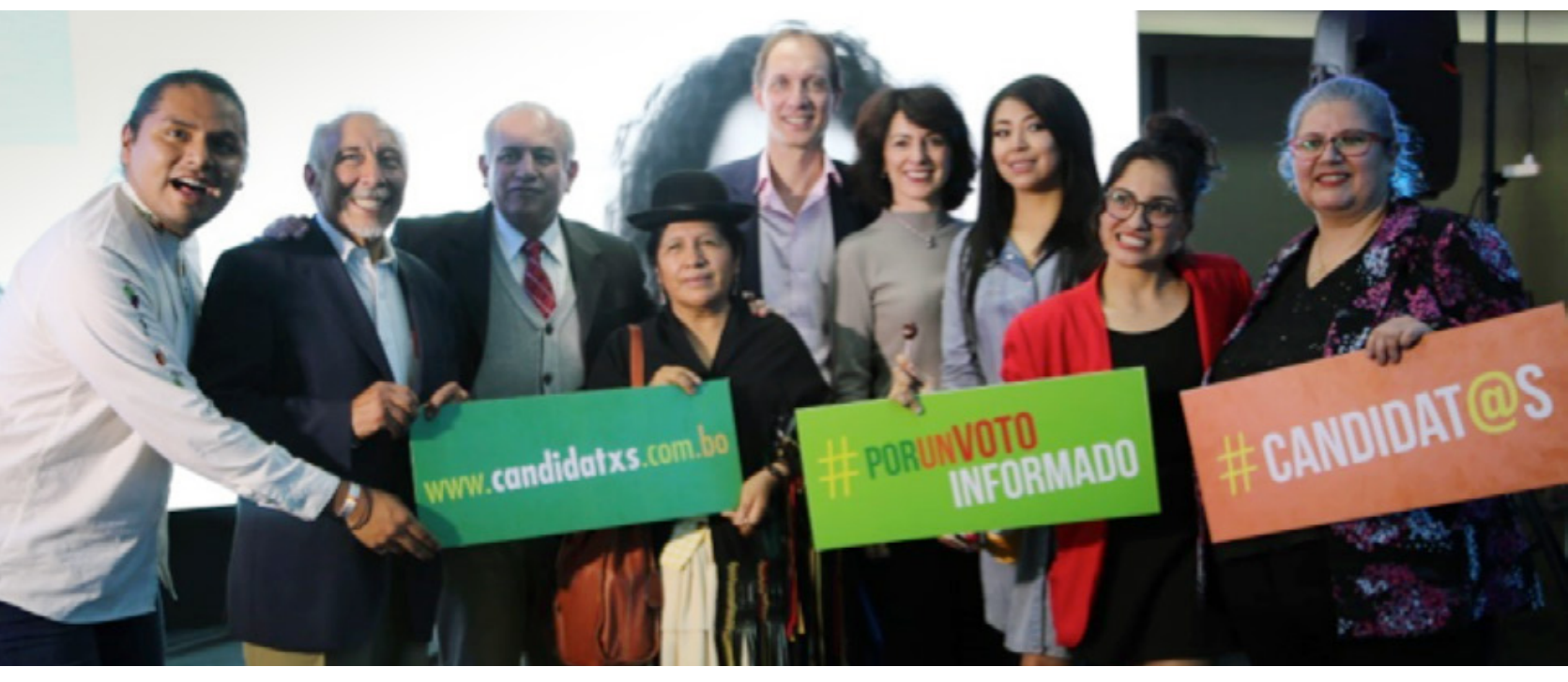

Supreme Electoral Tribunal (TSE) authorities and International IDEA Bolivia staff during the CANDI Dat@s launch.

'The use of CANDI Dat@s by young voters can determine the course of democracy.'

- Andres Gutierrez, Advocacy Platform Bolivia

For young Bolivians, sifting through information from nine political parties to figure out which one best represent them is a daunting task, which may result in an uninformed decision on election day. To reach young voters ahead of the 20 October 2019 election, International IDEA Bolivia, with funding from the German Embassy, developed the online tool ‘CANDI Dat@s: Advancement of the Informed Vote'.
The tool allowed young Bolivians to answer a set of 30 questions on issues of particular interest to young voter and compare their answers with those of each political party. Offering an interactive and easy overview focused on specific political issues helped users make a more informed choice.

The questions were put together by a team of experts and based on the work of youth platforms that have gained strength in the past few years. CANDI Dat@s was launched in September, a month before election day, and reached more than a million people through social media platforms. More than 300,000 people answered the questions in the month before the election.

The tool's communications team was made up of 130 young activists, who managed to stir the interest not only of citizens, but also of political organizations.

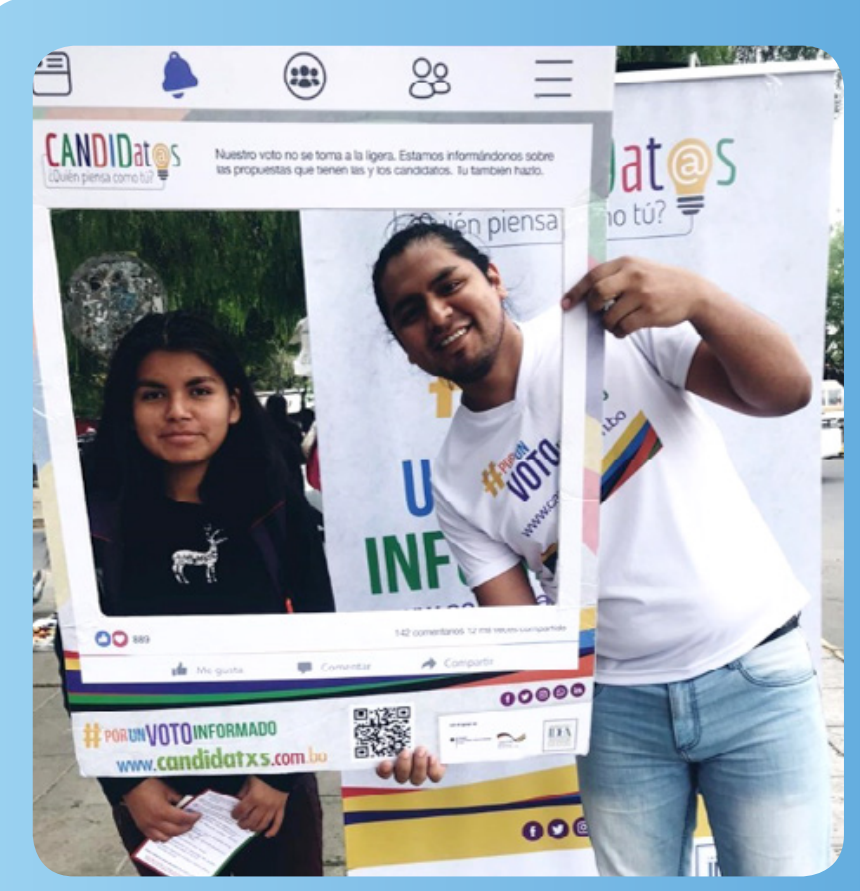

The tool became an important platform that contributed to the increase of knowledge and informed voting in this election, in which polarization and political confrontation overshadowed the importance of the programmatic proposals of the political organizations. The percentage of youth candidates increased from 39 per cent to 46 per cent in the 2019 election.

Due to a political crisis and an absence of trust in the electoral management body (EMB), Bolivia experienced a period of post-election conflict in which protests against the government and the election results led by groups of young people resulted in the annulment of the elections. A new government assumed responsibility for electing a new EMB. 
POLITICAL PARTICIPATION AND REPRESENTATION

\section{Ukraine: Party innovation hubs help spark political interest among young activists}

Political party innovation hubs in Ukraine help revitalize the appeal of democratic politics and citizen representation among young political activists.

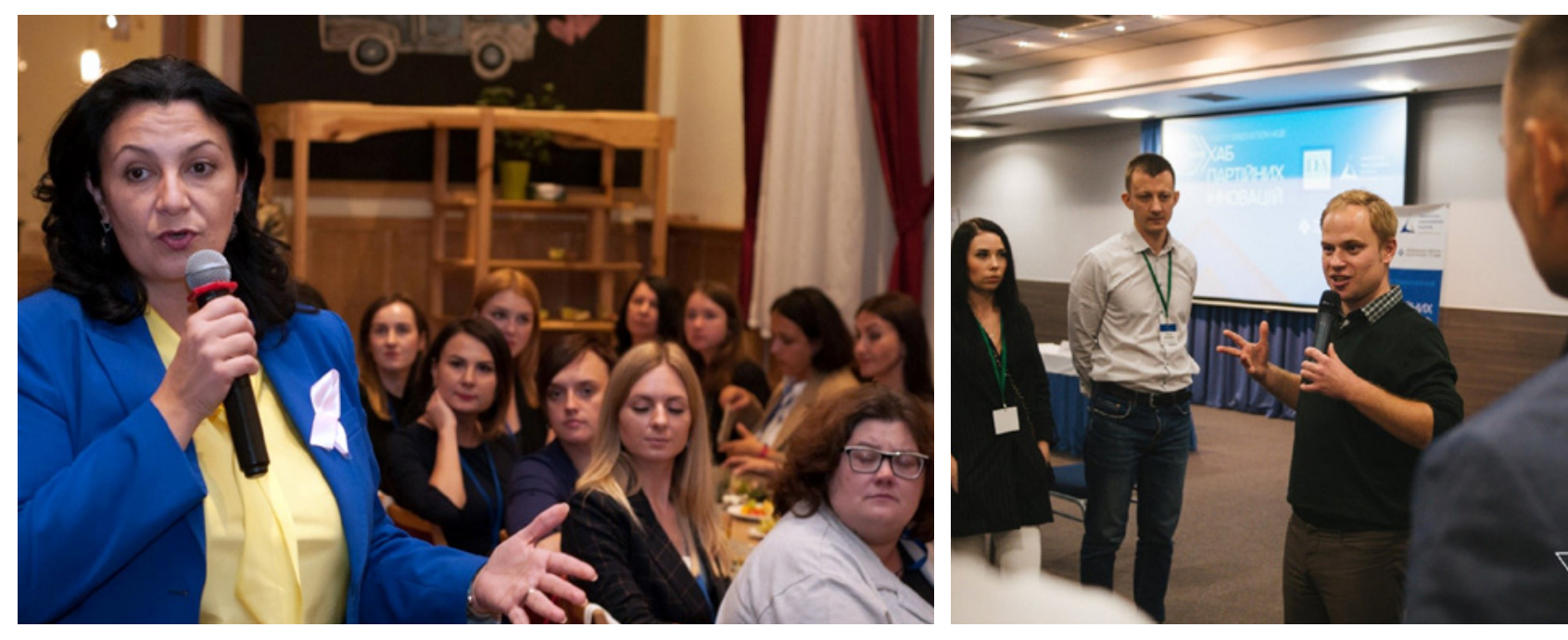

Left: Ivanna Klympush-Tsintsadze, former vice prime minister for European and Euro-Atlantic integration, speaking with participants of the Party Innovations Hub Women, held in October 2019.

Right: Yaroslav Yurchyshyn, former executive director of Transparency International-Ukraine and current Member of Parliament speaking with the Hub participants.

Political party innovation hubs are training sessions that focus on digital innovation and improved party-citizen connections. International IDEA developed the hubs in cooperation with the Ukrainian School of Political Studie in Kiev. The hubs equip young political activists with the latest knowledge and cutting-edge skills in using online and other tools to improve public outreach. They increase activists' understanding of citizens' needs, enhance the impact of democratic accountability tools, and ultimately narrow the gap between citizens and elected representatives in the democratic system.

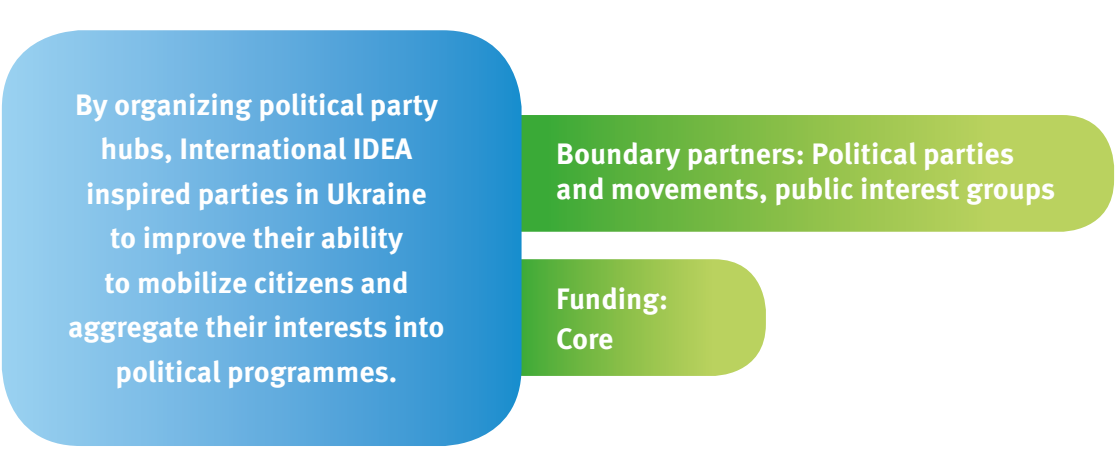

International IDEA hosted approximately 370 young party activists, community organizers, local elector campaign managers and regional party leaders at five hubs during 2018-2019. The participants included many representatives of smaller political parties that show interest in engaging and representing citizens than some of the more established parties. Three dedicated hubs for women party members, co-organized with the Council of Europe, brought together over 100 women local politicians and aspiring candidates.

The Hubs regularly feature trainers that have experience on electoral campaigns from European countries and the USA, as well as Ukrainian politicians from various parties and prominent democracy activists and watchdogs. Regular guest speakers include digital political communication and outreach experts who have direct, hands-on experience of digital innovation in politics. The Hubs also included speakers from international and Ukrainian media, and advocacy and political advisory outlets.

Since the 2019 elections, digital outreach to citizens has become a top priority of the Ukrainian administration. The Party Innovation Hubs have therefore supported a broader e-governance agenda. Three of the Hub participan have been elected to parliament, and others have been elected to various local councils. Participants have reported an increase in usage of innovative tools by local cells of their political parties for citizen outreach, advocacy and intraparty activities. 
POLITICAL PARTICIPATION AND REPRESENTATION

\section{Breaking down gender barriers in Paraguay}

Pushing gender parity and youth participation to the forefront of the political agenda

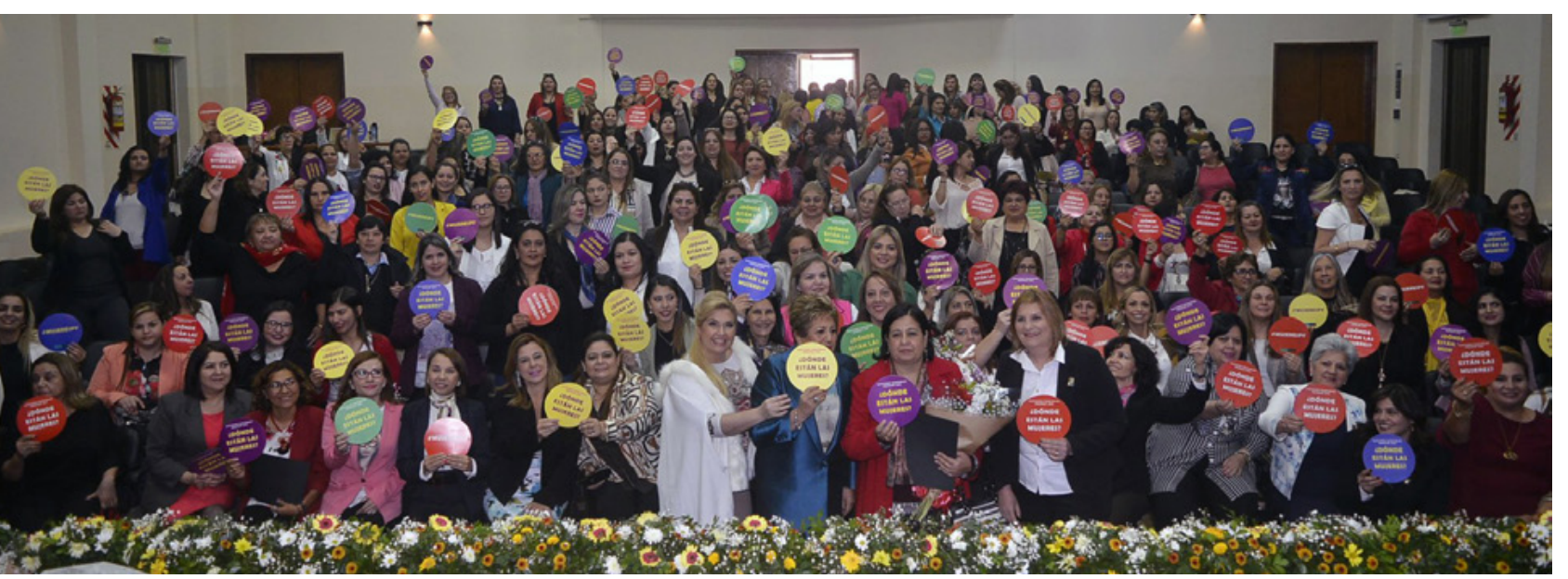

A meeting of women's networks in Paraguay, 24 August 2019.

Alejandra Sanabria and Maria Sol Arrúa, believe that politics should not change a woman when she gets involved with it. Instead, women should actively be changing the political system.

Sanabria, a 25-year-old Paraguayan, was one of hundreds who took part in a programme put in place by International IDEA in 2018 and 2019 that sought to empower women and young people in Paraguay. Programme participants are better prepared to take part in the political decision-making process and know more about how to run in upcoming elections.

Sanabria is a graduate of the EU-funded Political Training School for Women Leaders, a joint initiative of International IDEA and the Superior Tribunal for Electoral Justice, funded by the European Union with additiona support from the United Nations Development Programme.

The curriculum focuses on political participation, especially women's participation and gender equality.
Through the Political Training

School for Women Leaders,

International IDEA supports

the political party system in

Paraguay to becomstem in

Paraguay to become more

inclusive, responsive and

Boundary partners:

Political parties and movements

accountable to all citizens.

Funding:

European Union

'Something I learned is that when a woman gets involved in politics, the woman changes, but when many women get involved in politics, politics change.'

- Alejandra Sanabria, graduate, Political Training School for Women Leaders (quoting former Chilean President Michelle Bachelet)

The training and other programmes from International IDEA also generated opportunities for interparty dialogue in Paraguay. This led to discussions on the role of women and youth in the history of democracy as well as international good practices for the inclusive participation of women, youth, and other underrepresented groups in politics and elections.

International IDEA's work to build the inclusive participation of young voters and women helped to place gender parity at the forefront of the political agenda, helping to improve the quality of democracy in Paraguay.

After graduating from the Senate's Political Training Academy for Women, another International IDEA initiative led by Paraguay's Senate's Equity and Gender Commission with additional funding from Taiwan, María Sol Arrúa said it opened her eyes to getting more women involved in the political process.

'I realize now that all women, despite our differences, have a common struggle. I have found the purpose of normalizing female leadership and aspirations for public office. To be a young woman who wishes to be President of the Republic is normal!

- María Sol Arrúa, graduate, Senate Political Training Academy for Women 


\section{Breaking down gender barriers in Paraguay}

The six most significant programmes established by in Paraguay International IDEA with European Union funding are:

1. The Political Training School for Women Leaders;

2. Democratic Impulse for Youth, a joint initiatives with the Tribunal Superior de Justicia Electoral (Superior Electoral Tribunal) and the United Nations Development Programme (UNDP);

3. The Senate's Political Training Academy for Women, led by the Senate's Equity and Gender Commission with additional funding from Taiwan;

4. Level Up: Political Finance with Integrity, in partnership with the local organization, Semillas para la democracia;

5. The Political Finance working group with the Tribunal Superior de Justicia Electoral; and

6. Peace and Democracy workshops in collaboration with Paraguayan political parties youth sectors.

A total of 1,433 people have taken part in the programme between 2018-19 including 423 women leaders at the Academy for Women, the School for Women Leaders, and Democratic Gender Parity Group (Grupo Impulsor de la Paridad Democrática); 465 young voters (half of them women) in Democratic Impulse workshops; 327 young leaders ( 255 women and $72 \mathrm{men}$ ) in Level Up, and 218 young party activists ( 91 women and $127 \mathrm{men}$ ) in Peace and Democracy workshops.

This programme has created opportunities to promote interparty dialogue, knowledge sharing on the role of women and youth in the history of democracy, human rights, the constitutional and legal framework, electoral systems, use of new technologies, effective leadership skills for political and electoral campaigns, and advocacy strategies.

- EU-funded Promotion of Democracy through Capacity Development of the National Electoral Administration, December 2016 to September 2019.

- EU and Taiwan-funded Senate's Political Training Academy for Women, April 2019 to December 2019

- EU-funded Level Up: Political Finance with Integrity, January 2018 to December 2019.

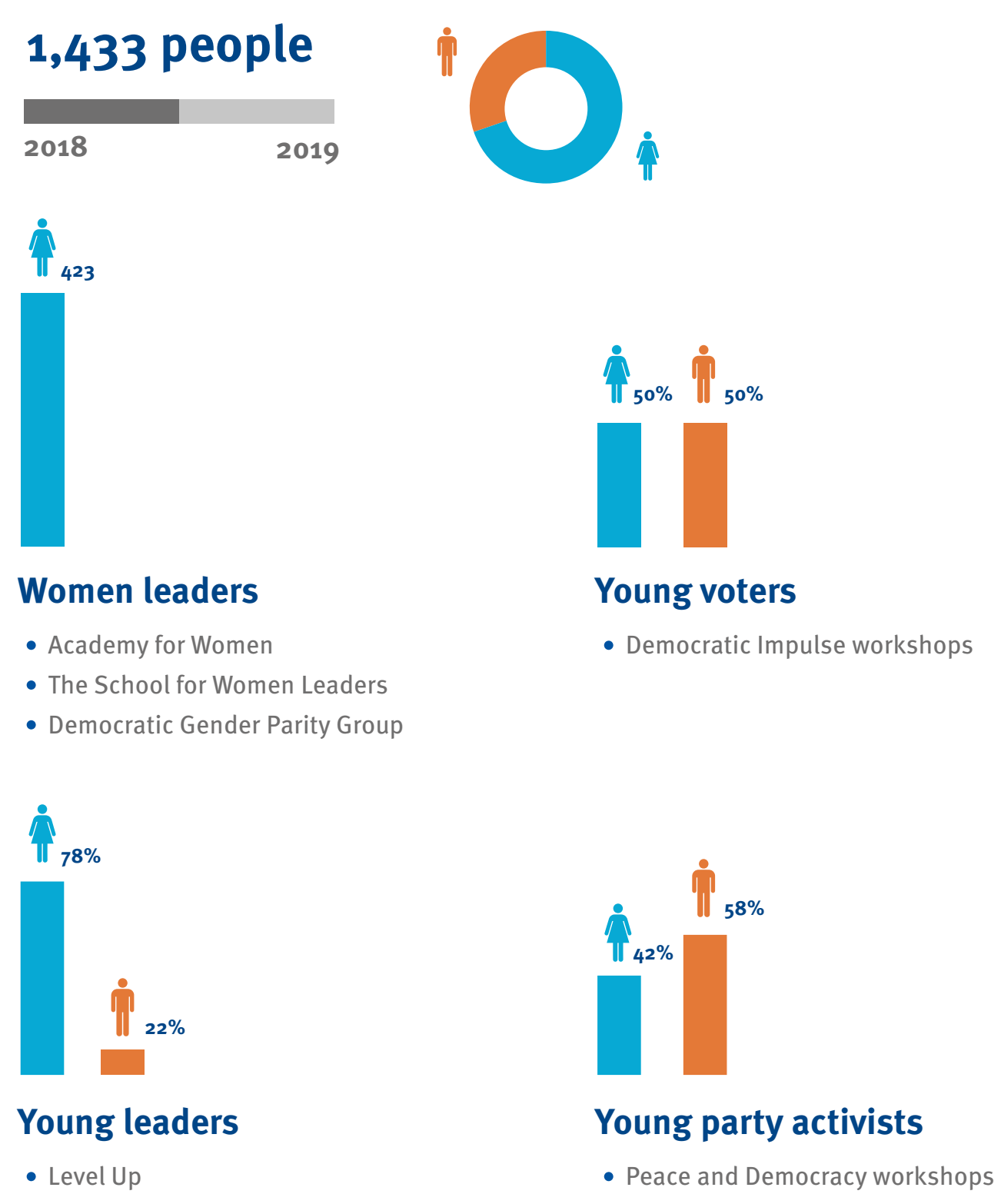


POLITICAL PARTICIPATION AND REPRESENTATION

\section{Fostering collaboration and citizen observation in Mozambique}

Observation teams contribute to improved data quality on voter turnout by gender

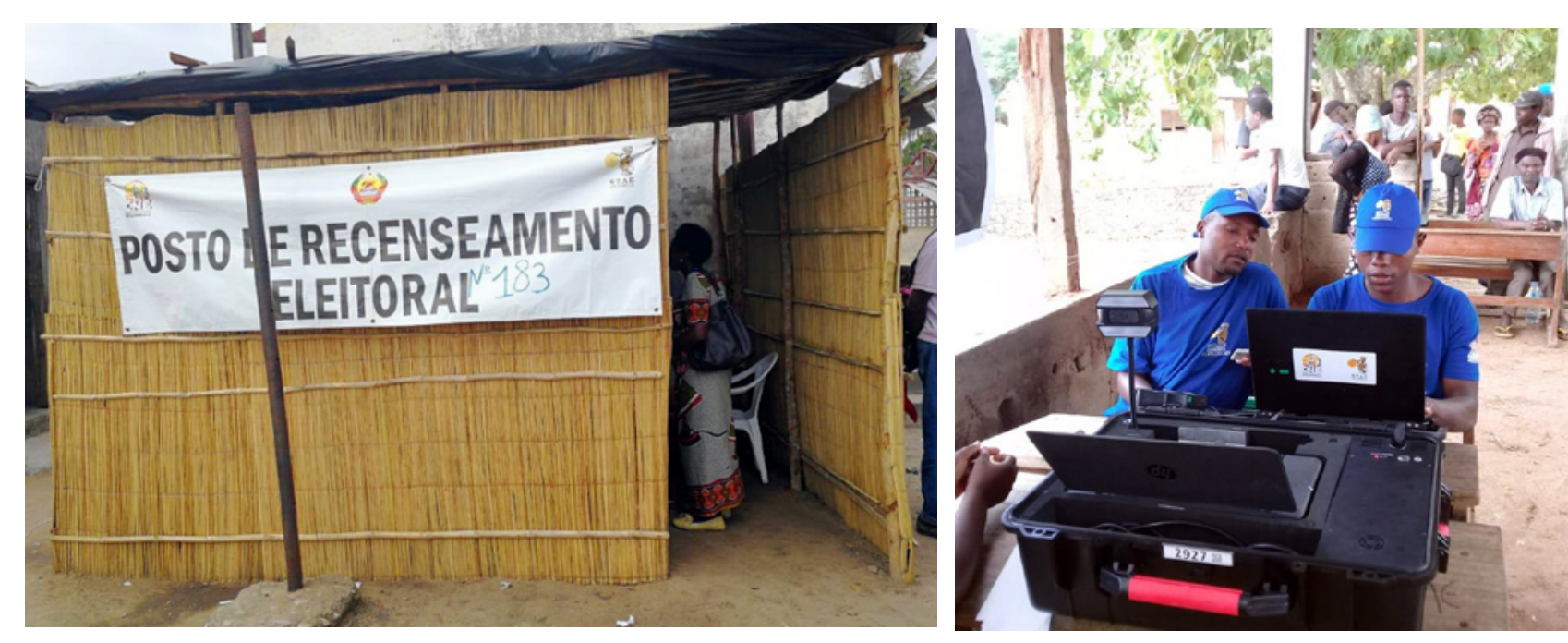

The EU-funded 'Support to Consolidation of Democracy in Mozambique Programme' worked with citizen voter registration officials, who created voter cards in rural conditions.

In Mozambique, the 2016 collapse of the Electoral Observatory, the country's main citizen observation platform, left a void in terms of coordinated and experienced election observation. To address this challenge, Internationa IDEA partnered with JOINT - Liga das ONGs em Moçambique, one of the largest civil society platforms in the country, and the Electoral Institute for Sustainable Democracy in Africa (EISA) to provide technical assistance and fund election observers for the 2018-2019 local and national elections.

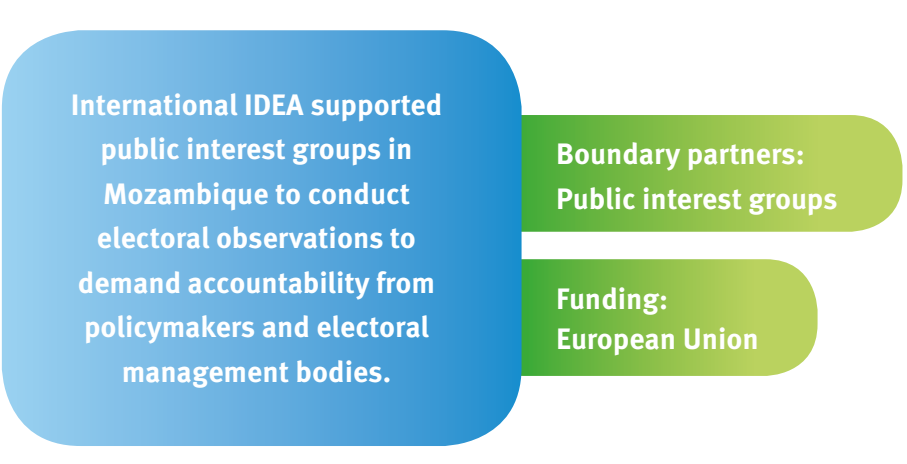

In addition to providing comprehensive training to observers, the partnership deployed 161 observers to monitor voter registration and conduct parallel vote tabulation during the campaigning period, as well as 2,500 observers on election day

The Institute's collaboration with EISA resulted in cooperation with a different set of public interest groups, with the purpose of conducting comprehensive observation of the electoral observation cycle. All organizations involved in the programme were able to increase the return on their investment, while improving the quality of election observation.

Adding to the efforts of International IDEA, EISA's initiative planned to deploy 400 observers for registration and campaigning, and 2,500 observers on election day. By harmonizing training and using common observation checklists and a joint reporting system, the quality of observation and assessment improved considerably and allowed a wider territorial and event coverage. This allowed joint teams of three observers to be deploved to observe registration in all districts, comprehensive coverage of the campaign events of all main candidates and parties in all districts, and the expansion of election day observation and parallel vote tabulation to 5,000 polling stations under a single statistical sample. The partnership's use of the large election day sample allowed for an estimate of a gender breakdown of voter turnout with a high degree of certainty, for the first time in the electoral history of Mozambique. 
POLITICAL PARTICIPATION AND REPRESENTATION

\section{Women leaders translate rights into outcomes in Central African Republic}

The Political Agreement for Peace and Reconciliation

International IDEA's work contributes to UN Security Council Resolution 1325 on Women, Peace and Security. The 2oth anniversary of this landmark resolution is commemorated in 2020.

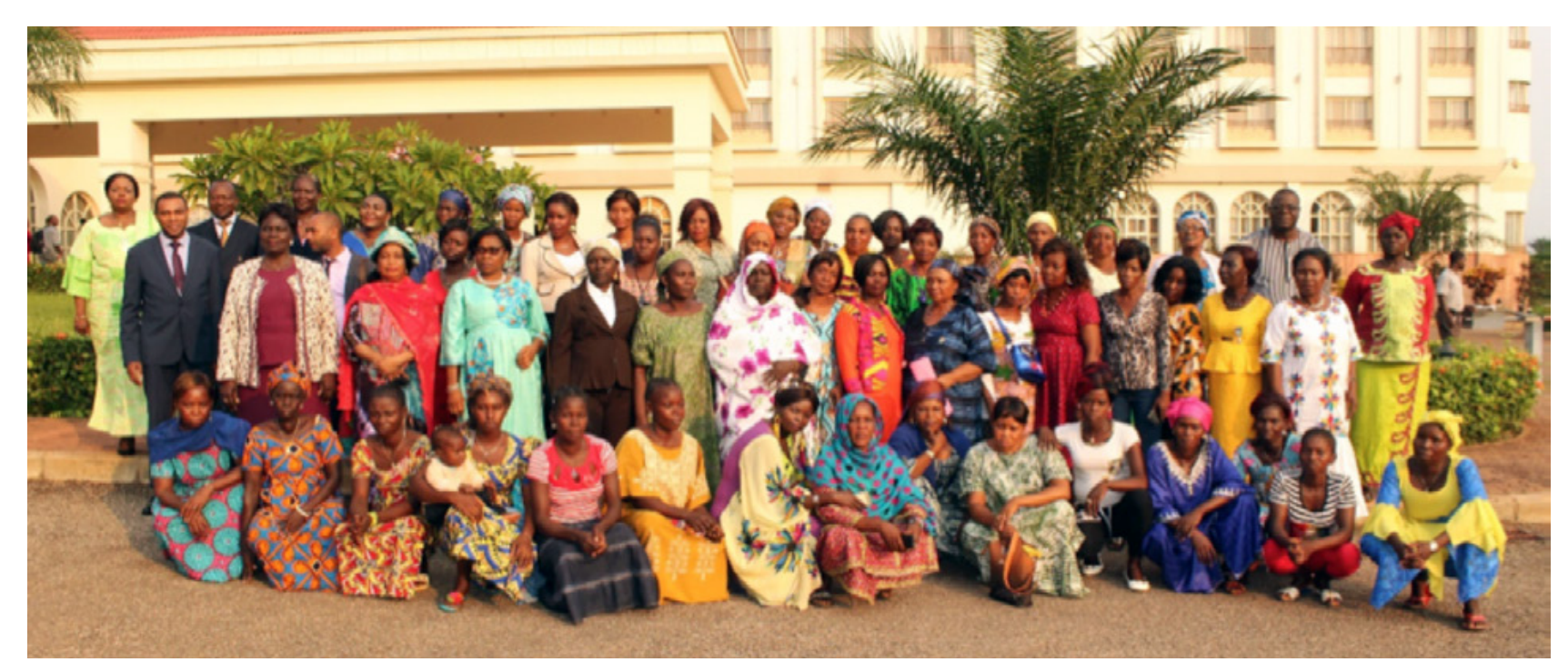

Participants of the 'Capacity Building Workshop for Women Leaders for a gender-sensitive Implementation of the Political Agreement for Peace and Reconciliation in Central African Republic' held in June 2019 in Bangui.

Women leaders suffered unspeakable atrocities during the conflict in the Central African Republic in which militias killed thousands and displaced many more. These women remain devoted to forging peace in their country and are doing so with help and support from International IDEA.

International IDEA hosted the 'Capacity Building Workshop for Women Leaders for a gender sensitive Implementation of the Political Agreement for Peace and Reconciliation in Central African Republic' held in Bangui on 17-18 June 2019. Participants included parliamentarians, 40 constituents from provinces occupied by

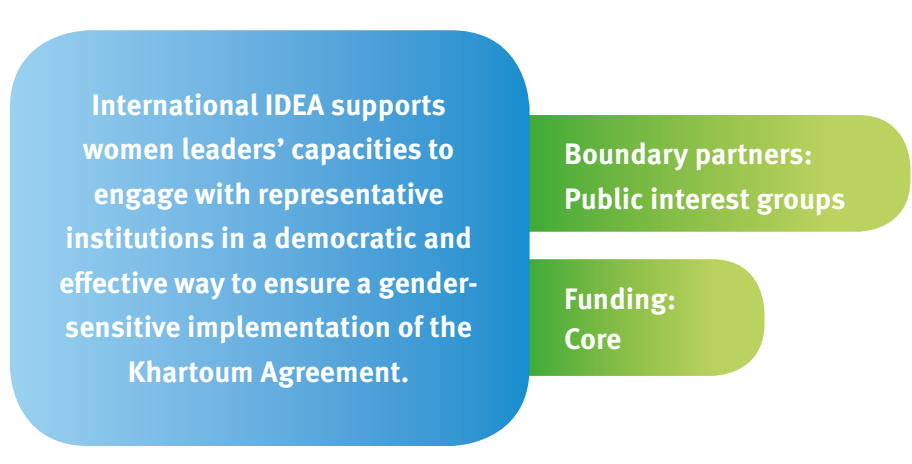

rebel groups that have signed the Peace Agreement, as well as representatives of other armed groups, five member of the agreement's monitoring mechanism, the first deputy speaker of the National Assembly, women members of government, senior experts from FEMWISE/African Union and the AU representative to the Central African Republic. The monitoring mechanism includes the Executive Follow-up Committee, the National Implementation Committee, the Prefectural Implementation Committee, and the National Programme for Demobilization, Disarmament, Reinsertion, Reintegration and the Repatriation Implementation Unit.

The workshop helped develop the capacity of women leaders in two ways. First, it created awareness of how women leaders can translate the rights assigned to women in the Khartoum Agreement into tangible actions. Second, it strengthened the participants' willingness and capacity to ensure the gender-sensitive implementation of the agreement. An important outcome of the workshop was that the participants drafted a tentative action plan on how to put these insights into practice.

In response to the participants' request—and in order to further promote gender-sensitive peace enforcement initiatives, advocacy and widescale women's oversight of the implementation process- the African Union Commission's Department For Political Affairs and International IDEA will provide 10,000 printed copies of the French and Sango versions of the Political Agreement for Peace and Reconciliation to the women leaders in the Central African Republic in 2020

'This training gives me a unique platform to vent, to hear the travails of my fellow women leaders and know that I am not alone in this struggle; to rekindle hope and re-channel that painful experience towards my leadership drive and efforts to implement the Khartoum Agreement; so that such horrendous crimes would not be repeated, and victims would find due justice.

-Workshop participant 
POLITICAL PARTICIPATION AND REPRESENTATION

\section{Promoting cooperation between political parties in Ethiopia}

Skills training for political parties in Ethiopia

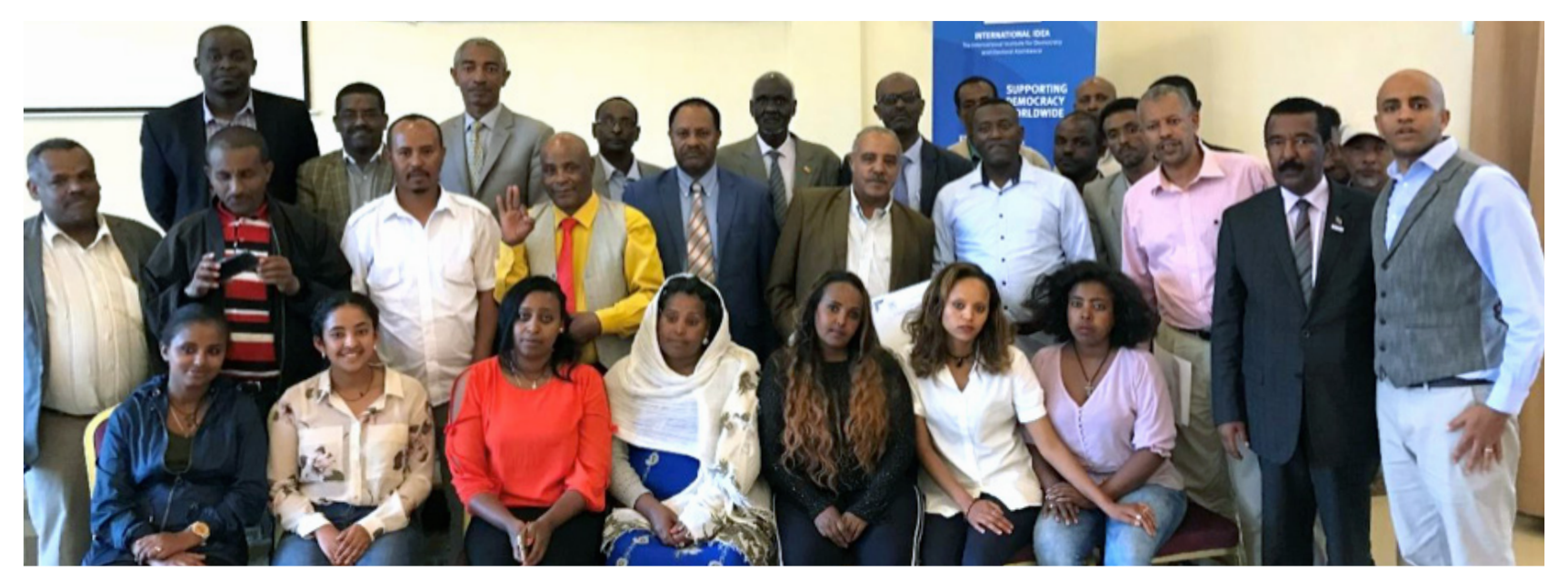

Participants of a 2019 Interparty Dialogue Skills training held in Ethiopia for several political parties.

In Ethiopia, competition between political parties has long been favoured over cooperation. But as the country undergoes rapid political changes, creating an atmosphere that facilitates consensus is key to the success of reforms.

Since the current Ethiopian government took office in April 2018, the country has experienced several positive and rapid changes related to political governance. The 2019 Nobel Peace Prize recipient and Prime Minister of Ethiopia, Abiy Ahmed, has led reconciliation efforts and called for unity and has met with opposition groups. He has announced a series of democratic reforms as well as the release of prominent political prisoners.

Given the complexity of the issues involved and the depth of socio-political polarization, creating an atmospher that facilitates consensus is key to the success of these reforms. Open, informed, thorough and context-sensitive dialogues must take place within and among political parties, as well as between them and other key stakeholders including public interest groups, the media and academia. Building consensus will increase ownership and the acceptability of the outcomes.

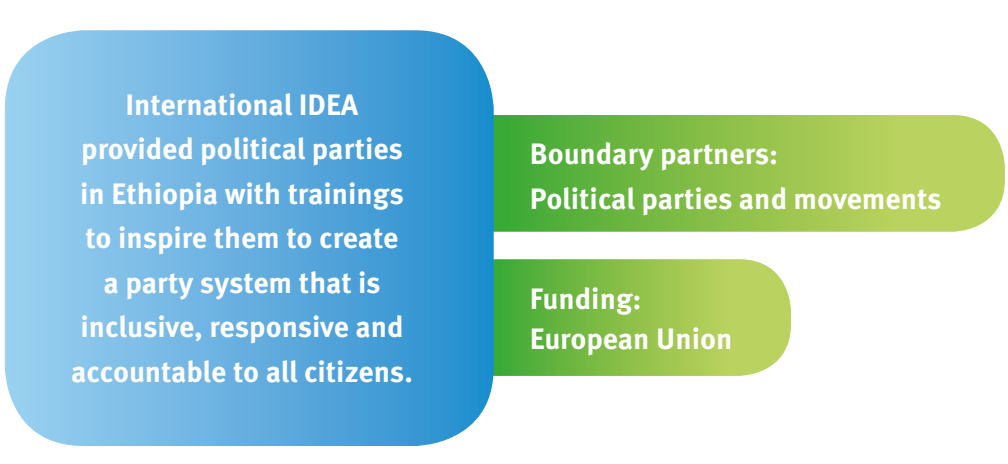

To this end, International IDEA's Africa and West Asia programme, in collaboration with the EU and local partners, successfully organized an interparty dialogue skills workshop for 30 national and 22 regional political parties in Ethiopia. Moreover, three training workshops, delivered 18-23 November 2019, focused on strengthening and repairing relationships between political parties by exchanging views, outlining their respective positions and taking steps towards reconciling these positions.

The feedback from these trainings has been positive with participants noting that it prompted them to exchange ideas with other political parties and build a consensus on the necessity to develop a roadmap for an inclusive reform process. The acquired dialogue skills are essential to facilitating healthy communication among representatives of political parties, ahead of an upcoming series of national dialogues on legal and institutional reforms that the current government is committed to undertake.

As a crucial building block of Ethiopia's transition towards sustainable democracy, the interparty dialogue skills training was widely covered by the country's major media outlets, including the Ethiopian Broadcasting Service, Walta Media and Communications Corporate.
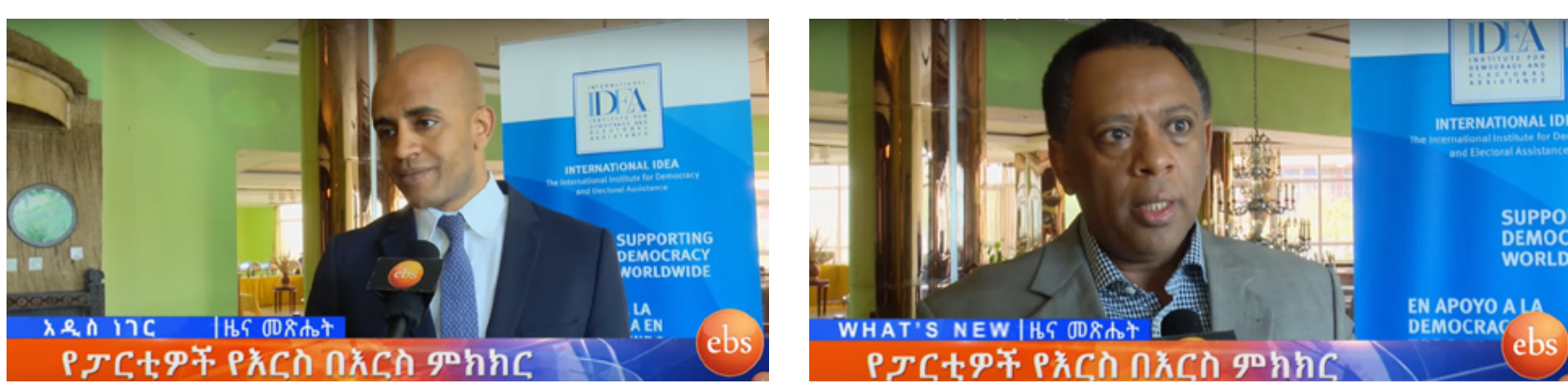

View (Ethiopian) local news coverage about this event:

Ethiopian Broadcasting Service (From 1:05 to 6:45 minutes only)

Walta TV (From 7:01 to 11:55 minutes only) 
POLITICAL PARTICIPATION AND REPRESENTATION

\section{A community's transition from 'no man's land' to an inclusive cultural space in Peru}

Creating a culture of democracy to re-envision the Monzón Valley’s future
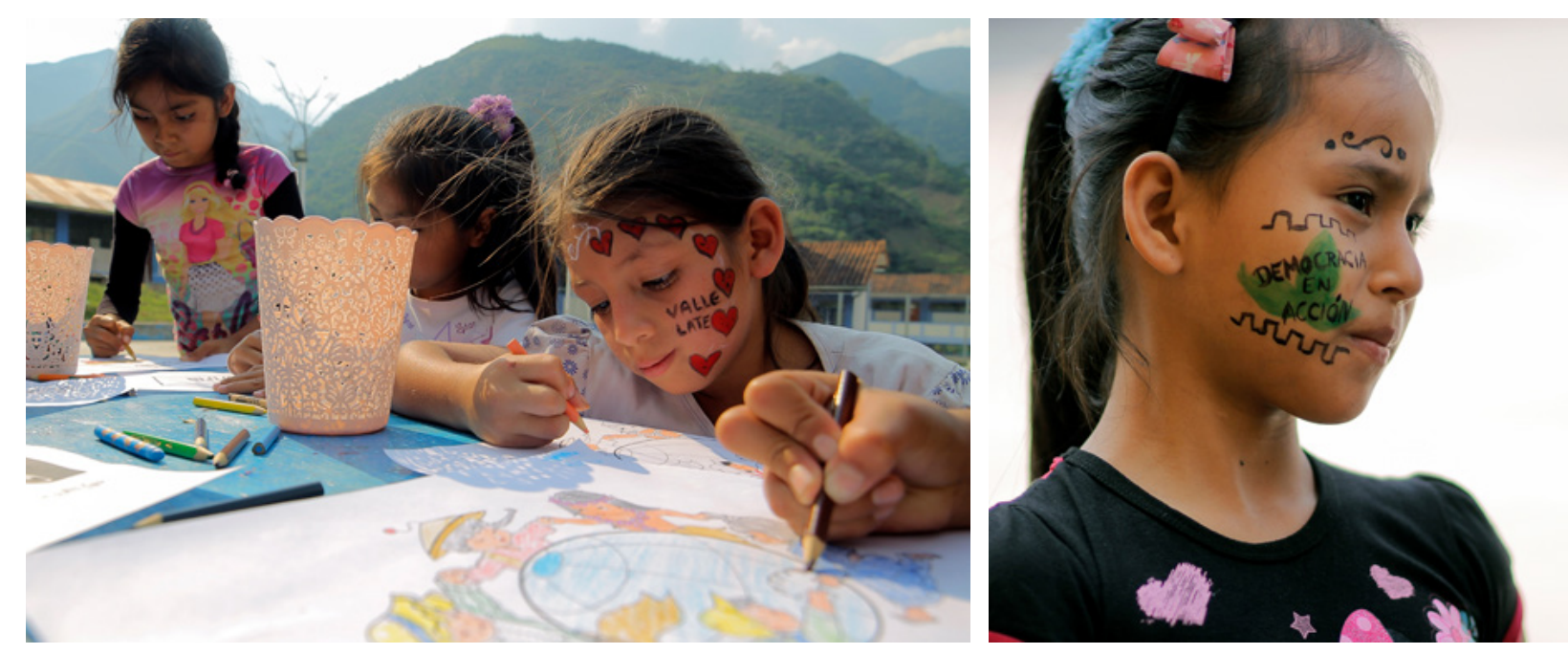

Young Monzón residents reclaim public space for cultural activities.

In the Monzón Valley in the Peruvian Amazon, drug trafficking, terrorism and violence has been the norm for over 30 years. About a decade ago, Monzón's economy was focused on the production of coca leaf for the illegal drug trade, producing 16 per cent of all illegal crops in Peru. The state had little control in the area, which was often described as 'no man's land'. The coca farmers union exercised very strict control over the zone, which was characterized by the expression 'coca or death'.

The drug production and trafficking network was closely linked to the Shining Path, a communist guerrilla organization that launched a war against the Peruvian state in the 1980s. The Shining Path provided armed protection for the coca leaf production, fuelling a growing distrust of the government. Terrorist acts in the Monzón occurred frequently, violating human rights and free transit.

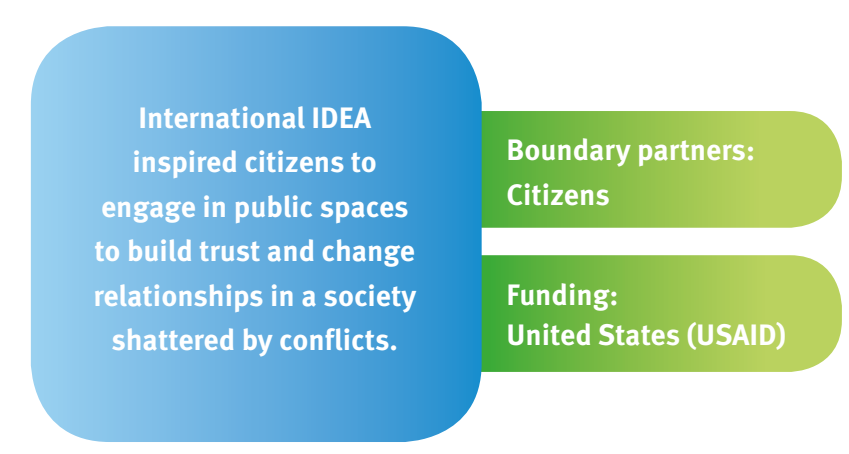

\begin{abstract}
'I am very happy to see that now this square is a place where people can entertain themselves as a family, until few years ago this same place was used for public executions, amons other forms of popular justice.'

- Mayor of Cachicoto Town
\end{abstract}

In 2012, the Peruvian government began a campaign to eradicate illegal coca farming in Monzón district, replacing coca with alternative crops such as coffee and cacao. The state also managed to set up three police stations allowing Monzón Valley and its inhabitants to initiate a process towards development, peace and inclusion. The process continued throughout 2018, when International IDEA began its work to support the process and strengthen democracy in public cultural meeting spaces.

In 2019, cultural fairs, theatre performances and cinema forums were organized to provide a forum where families could meet, learn, reflect and discuss important issues. The focus has been on democratic coexistence in society, but the events have also given people in the area an opportunity to enjoy public space in a new way. Feedback from Monzón citizens has been positive; many are surprised that the squares could be a centre of cultural activities.

This initiative, supported by the US Agency for International Development, has helped recognize that public space as a meeting point for culture can be a key to strengthening democratic coexistence, particularly in localities that have suffered long periods of violence and isolation, such as the Monzón Valley.
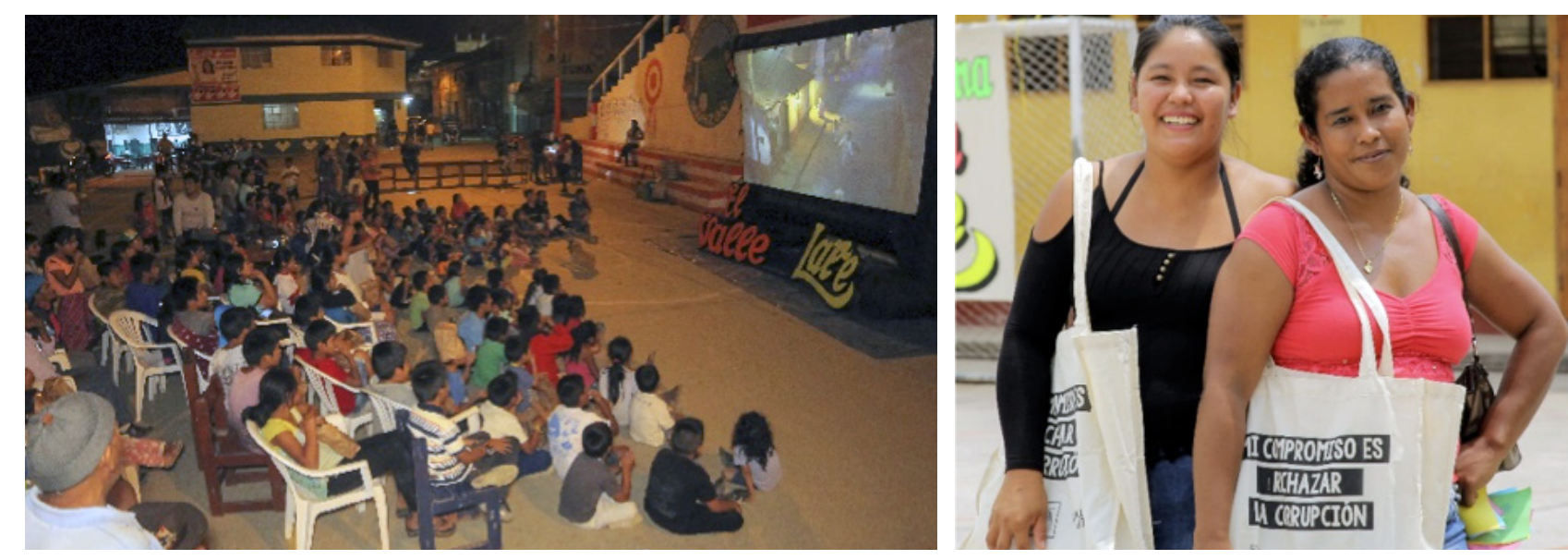

Citizens from Monzón Valley, Peru using public space as a cultural democratic meeting point. This valley suffered from terrorism, violence and isolation until 2014 
The Inter-Regional Dialogue on Democracy offers regional and global connections to achieve democratic sustainability, build peace and advance SDG 16+

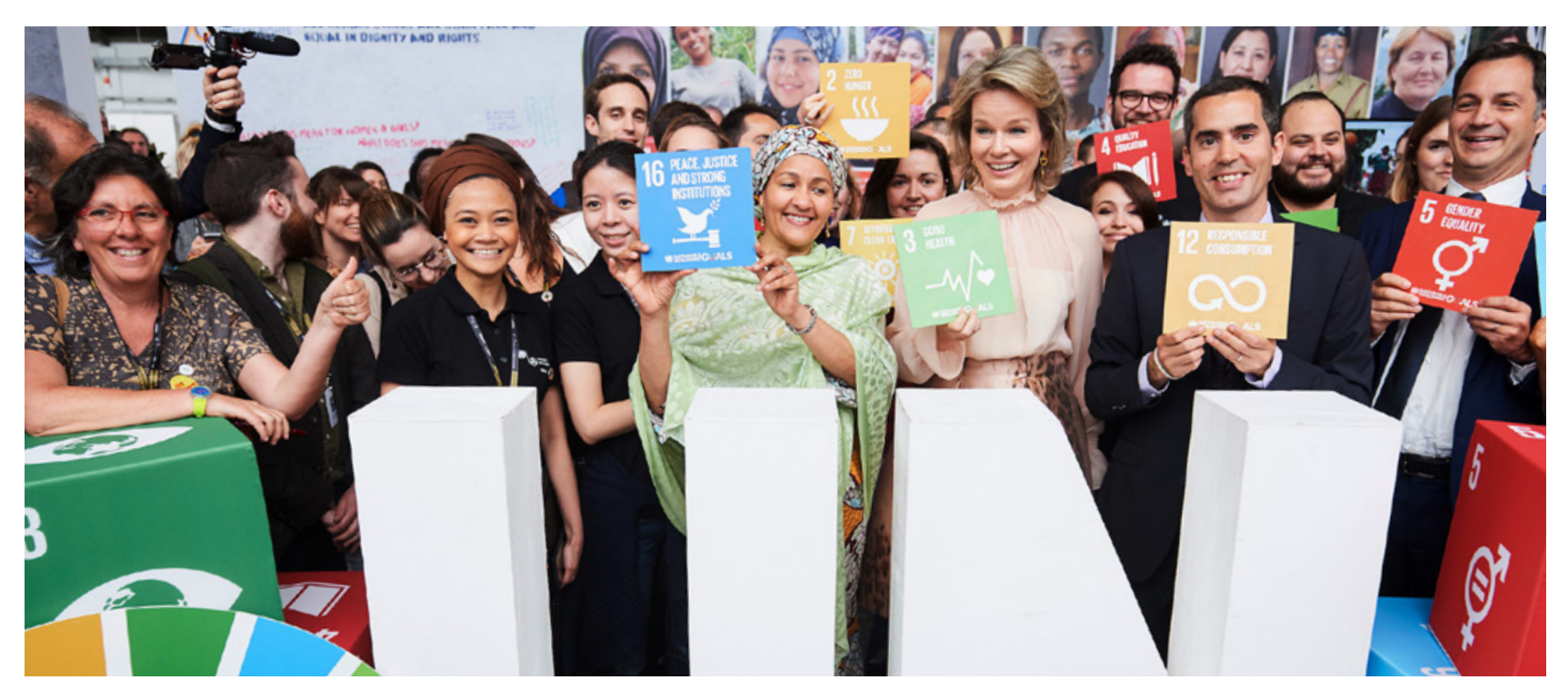

The connection between democracy, peacebuilding and development is instrumental to achieve progress, and to deliver on the 2030 Sustainable Development Agenda. The 2030 Agenda, together with the Sustainable Development Goals framework, is owned and driven by governments, but collaboration with relevant actors provides input to efforts by ensuring ownership by all stakeholders, and a comprehensive view of the needs and potential contributions from each relevant actor in the field.

Throughout 2019, the Inter-Regional Dialogue on Democracy (IRDD), together with key regional and global partners including the African Union (AU), the Association of South-East Asian Nations (ASEAN), the European Commission (EC), the Council of Europe (CoE), the League of Arab States (LAS), the Organization of American States (OAS), the Pacific Islands Forum (PIF), the Community of Democracies (CoD), the Global Partnership for the Prevention of Armed Conflict (GPPAC), International Development Law Organization (IDLO), InterParliamentary Union (IPU) and the United Nations (UN); as well as with governments, civil society and grassroots organizations, think tanks and universities, and the private sector, engaged in a conversation to identify challenges and opportunities around the achievement of SDG $16+$.
With the purpose of facilitating an open conversation and to strengthen the linkages between governments, global and regional organizations, civil society, academia, experts and practitioners, the IRDD enabled substantive spaces such as the 8th High-Level Meeting of the IRDD (Washington, DC - September 2019), the International Conference on 'Achieving Peace, Justice and Strong Institutions: The Role of Global and Regional Intergovernmental Organizations and Civil Society Actors' (Washington, DC-September 2019), the Inter-Regional Experts Meeting on Democracy and Peacebuilding in the framework of SDG 16 (Bogota, Colombia - June 2019), as well as the democracy forums (Busan, South Korea and Ulaanbaatar, Mongolia - 2019).

The IRDD was created in 2010 to provide a platform for global and regional organizations to meet on a yearly basis, at the technical and political levels, to discuss and exchange best practices on priority areas related to democracy and good governance. The efforts deployed by International IDEA through the IRDD in 2019 delivered the following outcomes:

1. Strengthened partnerships with actors working in the field of democracy support, sustainable development and peacebuilding at the local, regional and global levels. The IDLO and IPU were identified as new contributors to the IRDD, and the Melanesian Spearhead Group expressed their interest in being part of the platform.

2. Enhanced engagement with International IDEA Member States (Mexico, Mongolia, Norway, Spain, Sweden, and Switzerland) provided a space for exchange among development agencies and diplomatic representations, which enabled an exchange of information regarding needs and priorities in certain contexts (i.e. supporting the peace process in Colombia).

3. Knowledge and policy recommendations produced on the advancement of SDG 16+ 'Peace, Justice and Strong Institutions', including the finalization of the discussion paper Democracy and Peacebuilding in the Framework of SDG 16+: Policy Recommendations from an Interregional and Multistakeholder Approach.

4. Increased visibility of International IDEA among potential Member States and partners, including think tanks and research centers working in the field of democracy support and good governance, that recognize International IDEA as leader in the development of knowledge and in the implementation of projects at the global, regional and country levels. 


\section{Helping to shape democratic governance} at the European Union level

The Office of International IDEA to the European Union (EU) merged with the Wider Europe Programme to become the Regional Europe Programme (REP) in January 2019. The mission of this Brussels-based office is to ensure the development and implementation of International IDEA's programmes in Europe and to represent the Institute at EU institutions and to Belgium as a Member State.

The REP focuses on delivering assistance to governments and civil society actors in countries in Eastern Europe and the Western Balkans in the fields of electoral support, constitutional design, accountability and inclusive democracy. In the framework of its liaison function, REP manages advocacy initiatives regarding EU democracy policy and relations with Brussels-based partners. It is also responsible for building International IDEA's partnership with the EU as a donor and facilitating EU fundraising for the Institute.

Responding to the EU policy priority to promote democratic governance within its borders and globally, the REP increased efforts to influence EU democratic governance policies in 2019. The EU Council Conclusions on Democracy, adopted by the 28 foreign affairs ministers on 14 October 2019, included some of the recommendations and text suggestions formulated by the REP and shared with representatives in Brussels of International IDEA's EU Member States.

The REP developed a Statement on the future EU Action Plan on Human Rights and Democracy and promoted it at the EU level, leading to an increased awareness on some major attention points and their inclusion in the preparatory phase of the policy initiative. A Joint Statement was developed with the European Partnership for Democracy and the European Network of Political Foundations on the role of democracy support in EU external actions and recommendations for the EU Neighbourhood, Development and International Cooperation Instrument and discussed with key actors in EU institutions and EU Member States' representatives.

The REP organized and co-organized five successful events targeted at shaping the EU democracy agenda, including a global launch of International IDEA's The Global State of Democracy 2019 report in Brussels, conference on 'The State of Democracy in East-Central Europe: Thirty Years after the Fall of the Berlin Wall', an annual conference on International Democracy Day 2019 on 'No Democracy without Accountability', a roundtable on Timing and Sequencing of Transitional Elections, and, in collaboration with the European Commission, a roundtable on 'Artificial Intelligence: Mapping Priority Areas for EU Assistance to Democratic Development'.
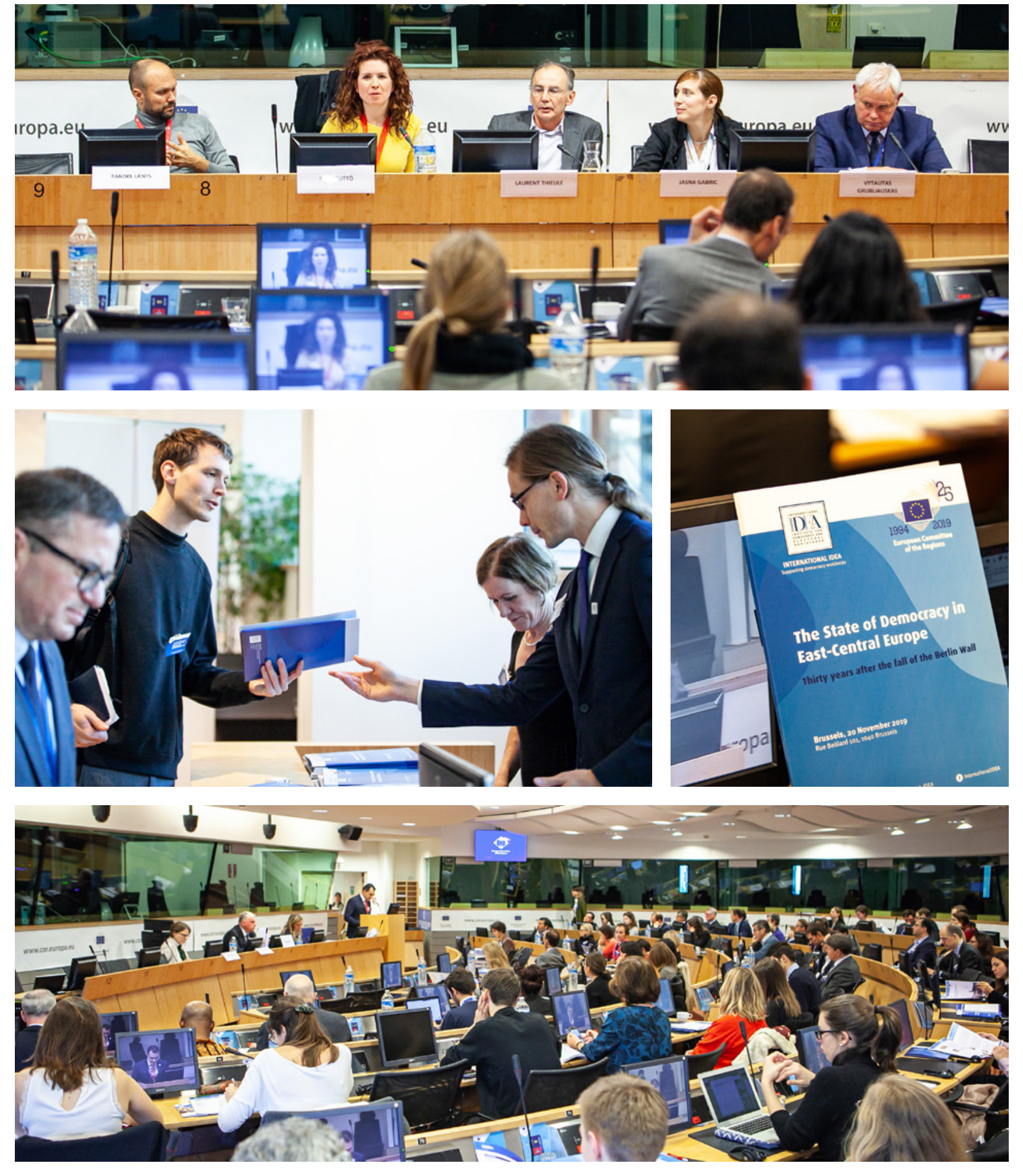

International IDEA and the Committee of Regions co-organized the panel discussion, 'The State of Democracy in East-Central Europe: Thirty Years after the Fall of the Berlin Wall', held in Brussels, Belgium in November 2019. 


\section{9 review}

\section{in numbers}


International IDEA in the news and knowledge resources

\section{Geographic spread of media mentions}

Top 10 countries for media mentions
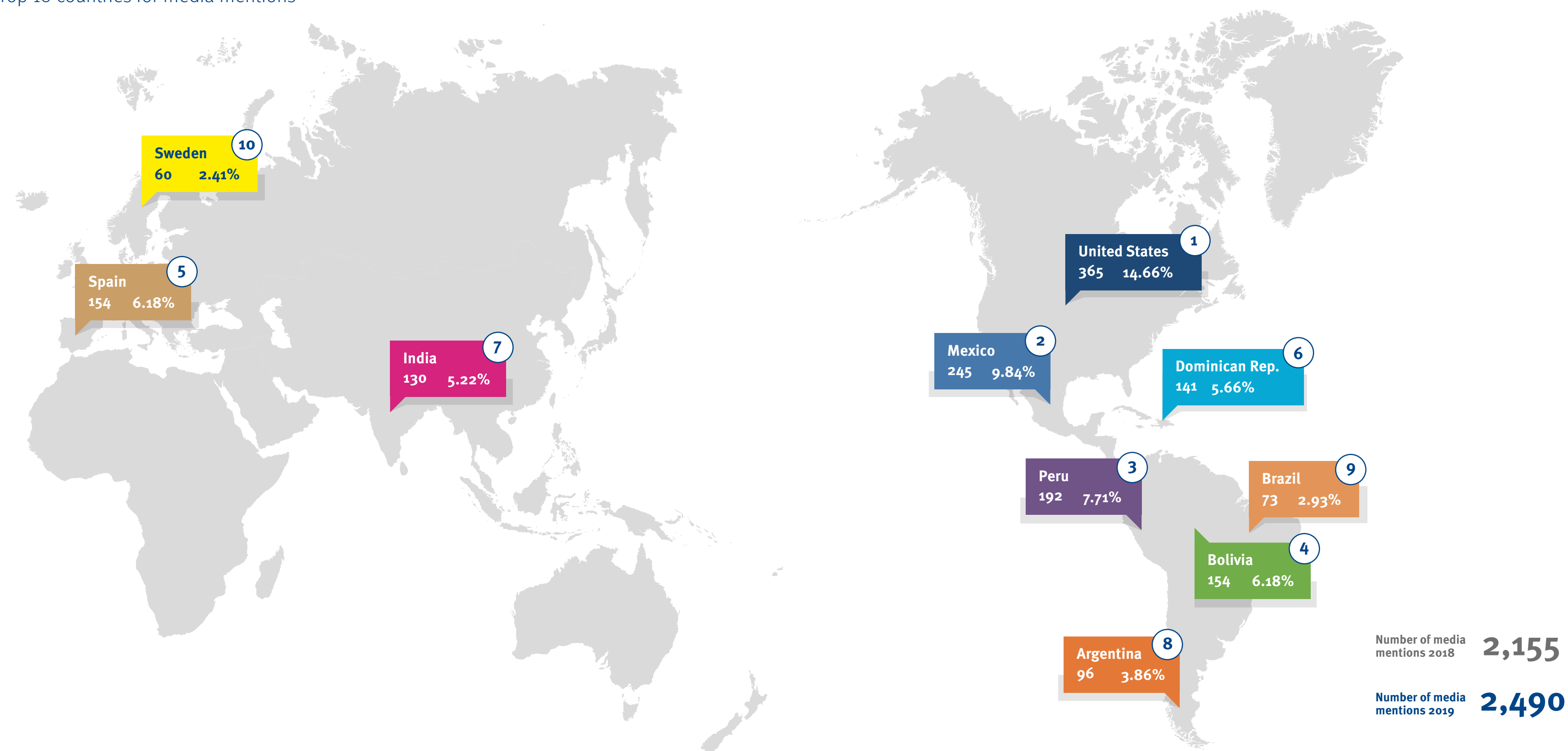
Top 10 International IDEA publications

By number of citations from products published since 1995

International IDEA 2019 publications produced

By type

固)

Electoral System Design:

The New Internationa

IDEA Handbook

\section{1,150}

814

Women in Parliament:

Beyond Numbers

Reconciliation after Violent

Conflict: A Handbook

La política importa: democracia y desarrollo en América Latina

Tratado de derecho electoral

comparado de América Latina

Funding of Political Parties and Election Campaigns: A Handbook on Political Finance

Voter Turnout Since 1945: A Global Report

Mujer y política. El impacto de las cuotas de género en América Latina

Assessing the Quality of Democracy: A Practical Guide

Voting from Abroad:

The International IDEA Handbook

\section{3}

289

235

192

153

132

107

91
Policy Paper

Guide

Report

GSoD In Focus

Background/technical document

Constitution Brief

Discussion Paper

Overview

Primer

Curriculum

Case study

Event report

Information Brief

Institutional

Internal document

Policy Brief 
International IDEA 2019 publications produced By language

圆) Total $\mathbf{5 8}$

English

Myanmar

Spanish

Arabic

French

Portuguese

\section{Number of publication downloads}

Top 10 countries

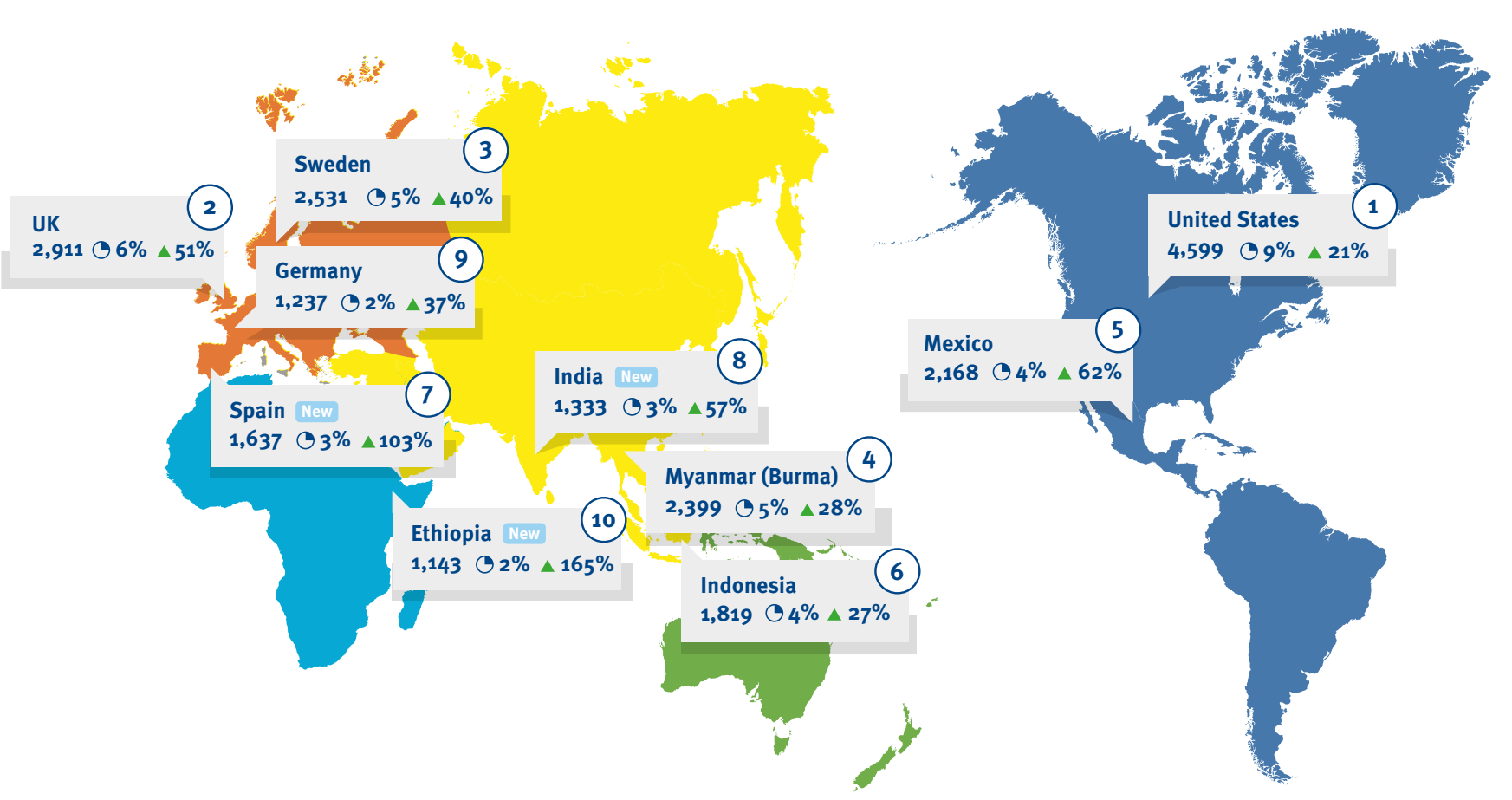

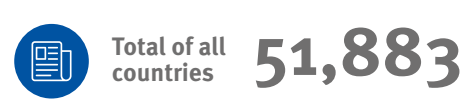

\begin{tabular}{|c|c|c|}
\hline Europe $16,092 O_{31} \% \triangle 49 \%$ & Asia $12,506 \quad 024 \% \triangle 19 \%$ & Americas $13,425 O_{26} \% \triangle 29 \%$ \\
\hline Africa $8,293 \quad O_{16} \% \triangle 29 \%$ & Oceania $1,513 \bigcirc 3 \% \triangle 15 \%$ & $\square$ Not set $54 \odot 0 \% \triangle 69 \%$ \\
\hline
\end{tabular}




\section{Top 10 publications downloads}

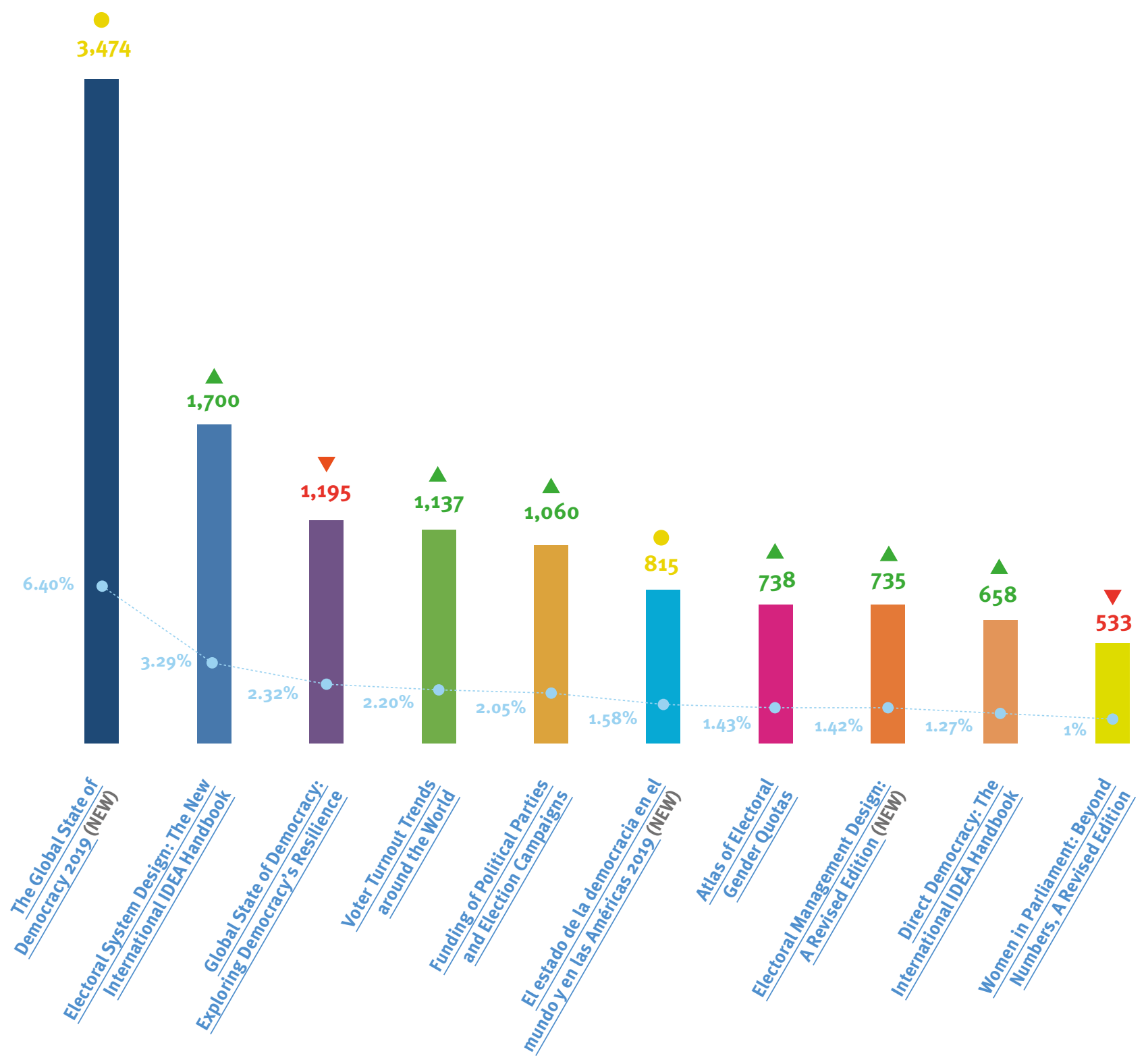

\section{Top News}

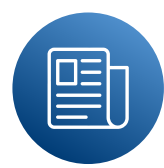

Number of visits

1. The case for/against direct democracy 2,923

2. The instruments of direct democracy 2,463

3. Social movements are here to stay - a part of our democratic way of life $\quad 2,149$

4. Challenges and opportunities for democracy in the 21st century 2,066

5. International IDEA's Council appoints Kevin Casas-Zamora as the new Secretary-General $\quad \mathbf{1 , 9 9 2}$

6. La democracia latinoamericana enfrenta su crisis de la mediana edad 1,449

7. Vacancy for the position of Secretary-General 1,390

8. The Crisis of Representation 1,305

9. The role of technology in identifying and avoiding electoral risks $\quad \mathbf{1 , 2 0 7}$

10. Political inclusion is vital to sustainable democracy 1,119

11. New government in El Salvador $\mathbf{1 , 1 1 6}$

12. Women's participation in local government 1,085

13. How to increase youth participation 1,017

14. Gender equality in Nepal: at a crossroads of theory and practice 841

\section{Top Events}

1. Call for Applications - Constitution Academy (November 2019) 1,744

2. The State of Democracy in East-Central Europe: 30 years after the fall of the Berlin Wall 1,212

3. Global launch of the Global State of Democracy 2019 Report: Addressing the Ills, Reviving the Promise 1,072

4. $\quad$ Launch Conference INTER PARES | Parliaments in Partnership - EU Global Project to Strengthen the Capacity of Parliaments 978

5. The Role of Youth in Peace and Security Dialogue 901

6. Constitutional Design of Semi-presidential Systems: Reflections for Ukraine 855 


\section{Assessing our results}




\section{Results framework}

International IDEA's system for results management, or learning-based management as we call it, is informed by the latest thinking and understanding of complex social and democratic change and is inspired by theory of change and outcome mapping methodologies. It is focused on mapping out or 'Hilng in' what is often described It hes so by paying special attention to trees doctices by the institutions and actors that Internations as boundary partners in the results framework.

In our system for learning-based management, the Institute identifies three levels of results:

1. The first level relates to International IDEA's performance-the products and services we deliver within our three impact areas: electoral processes, constitution-building processes, and political participation and representation. To assess and report on performance, eight output categories, with 15 standardized outpu indicators, have been established. Performance data on the 15 output indicators are collated in biannual activity reports submitted to International IDEA's Council of Member States.

2. The second level relates to outcomes within International IDEA's sphere of influence. Outcomes are defined as changes in behaviours, relationships and practices by the institutions and actors with which International IDEA interacts (our so-called boundary partners). International IDEA has identified 13 categories of boundary partners and submits a representative set of examples of changes we have contributed to among these boundary partners in an annual outcome report for the Council of Member States. This is the second of such report.

3. The outcome objectives are linked to a set of impact objectives and impact indicators to which Internationa IDEA contributes indirectly, which relate to four SDG targets: 5.5, 16.3, 16.6 and 16.7. The impact indicator consist of a mix of attributes, subattributes and indicators from International IDEA's Global State of Democracy Indices. In International IDEA's system for learning-based management, analyses of impact indicators influence the annual planning process, where we make strategic choices regarding where and with whom we shall undertake our activities. The outcome of this process is documented in each year's Programme and Budget, which is presented to the Council of Member States annually.

This results framework is underpinned by the following theory of change:

SDG 16.3: Promote the rule of law at the national and international levels.

16.

SDG 16.7: Ensure responsive, inclusive, participatory and representative decision-making at all levels.

$\mathbf{r}$

\section{Impact}

The constitution is implemented under agreed constitutional frameworks an contributes to reduced tension and conflicts.

4

Constitutional implementers interpret and operationalize constitutional provisions following ratification in a manner that respects fundamental democratic priniciples and human rights. They promote respect for the rule of law and constitutionalism under agreed constitutional frameworks.

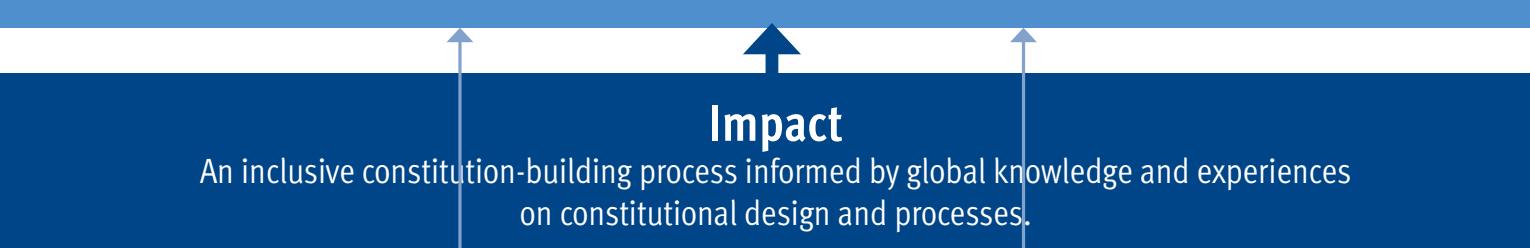

r

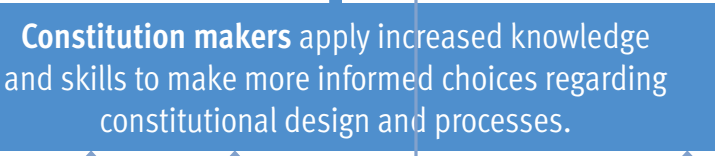
constitutional design and processes.
Civil society hold constitution makers accountable, Civil society hold constitution-makers accountable,
inform the public on constitution-building processes and promote public participation in the process. promote public participation in the process.
Advisors to constitution makers utilize International IDEA's knowledge and networks to give high-quality advice to constitution makers, civil society and constitution implementers. They expand coordination and collaborat on in a coherent and communicative community of practice to advance good practices in constitution-building prosesses.

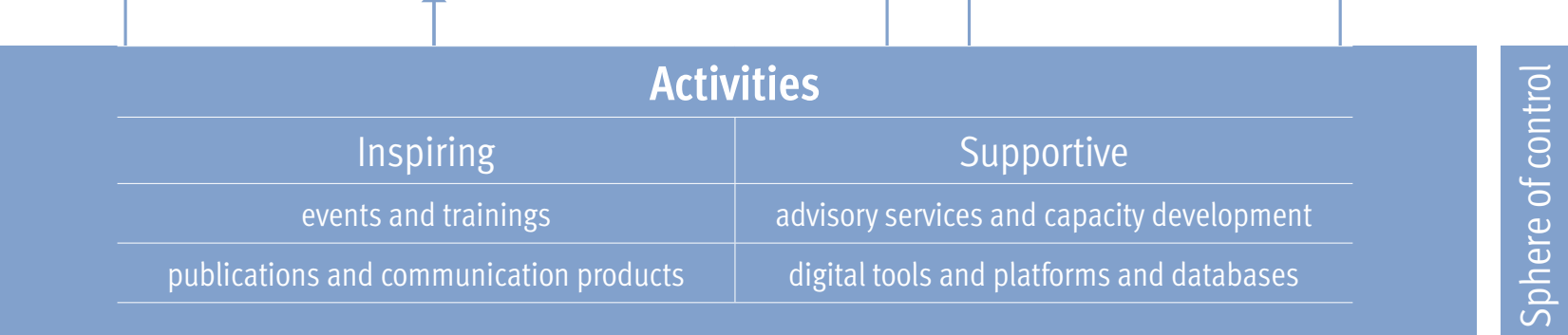




\section{Assessing our results}

Performance

The performance level of the results framework groups International IDEA's products and services into eight complementary approaches, which are labelled output categories. Figure 1 illustrates that some of these approaches aim to inspire institutions and actors to engage in change processes. Such inspiring work is a crucia

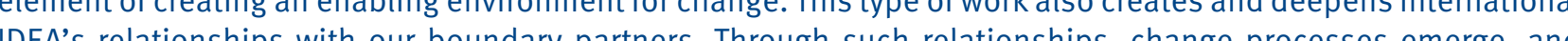
tailored supportive wippraches can be developed.

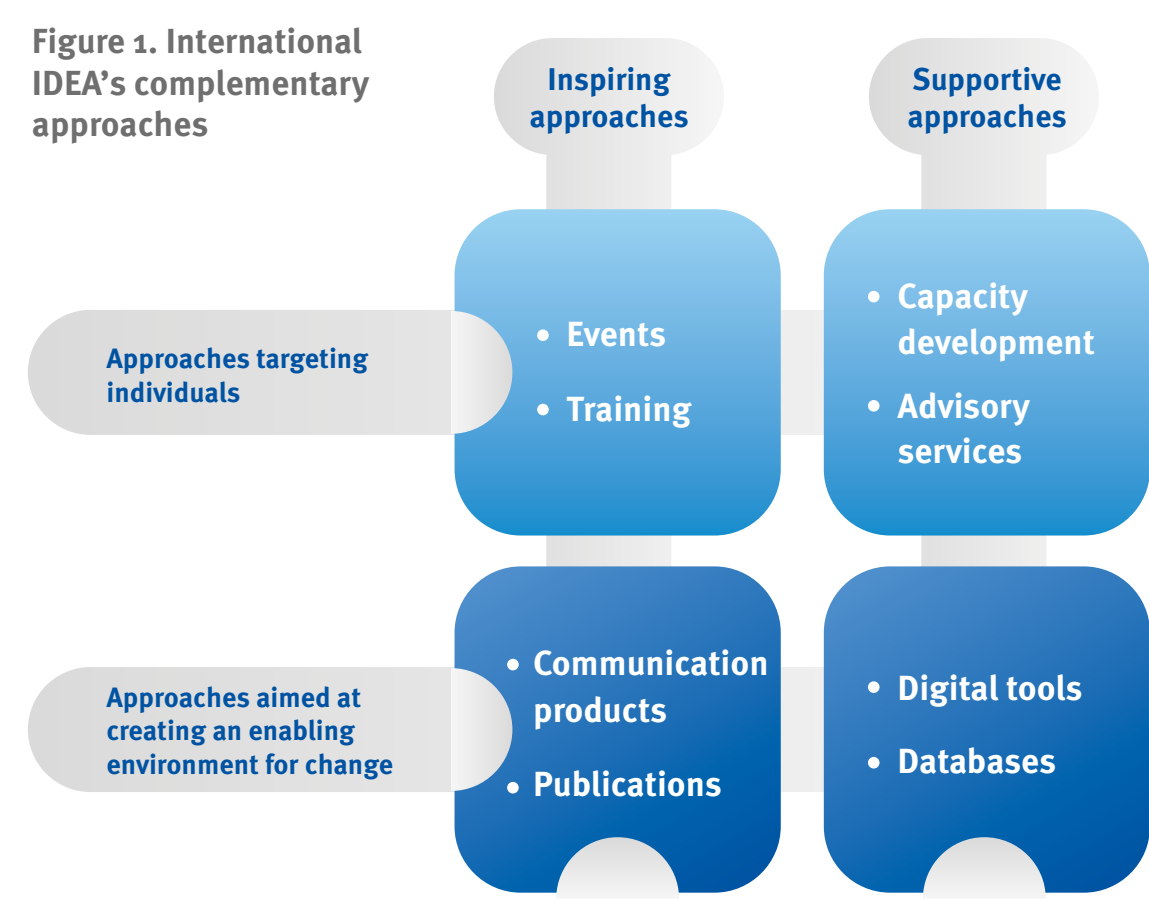

Figure 1 shows that inspiring face-to-face (i) events and (ii) short trainings in combination with (iii) communication products and (iv) publications on recent experiences and best practices can help our boundary partners to increase their awareness about the possibility of change and strengthen their skills and knowledge for change. If the boundary partners are inspired to change International IDEA offer another four approaches aimed at supporting them in this endeavour. Through (i) targeted capacity development and (ii) advisory services, the Institute engage face to face with boundary partners to support them in adopting new behaviours, practices and relationships within their respective political systems, and by producing (iii) digital tools and platforms and (iv) databases we provide them with tools to work on their change processes without our direct assistance.

Outcomes

The eight approaches outlined work together to stimulate outcomes-changes in the behaviours, relationships and practices of our boundary partners. For each type of boundary partner International IDEA interacts with, the fhe three impact areas.

Table 1. International IDEA's boundary partners and outcome objectives

\section{ELECTORAL}

PROCESSES

Boundary partner

Electoral management bodies

Electoral assistance practitioners

Policymakers

Civil society

\section{Outcome objective}

Recognize and respond to complexities and risks in the electoral processes, and effectively implement the electoral cycle approach. Embody principles of impartiality, egrity, transparency, efficiency, professionalism and service-mindedne ss.

Provide support, informed by norms, good practices and research in electoral processes. Contextualize norms, practices and research to local conditions.

Wake more informed choices to support practices that foster inclusivity and accountability in electoral processes. Recognize and consider risks in these processes.

Engage and collaborate in national and international discourse on electoral reforms in informed and effective way. Demand accountability from policymakers and electoral

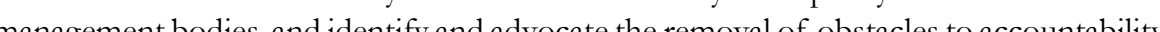
to promote public participation. 


\section{Assessing our results}

CONSTITUTION-BUILDING

\section{PROCESSES}

\begin{tabular}{|l|l|}
\hline Boundary partner & Outcome objective \\
\hline Constitution makers & $\begin{array}{l}\text { Apply knowledge and skills to make more informed choices regarding constitutional } \\
\text { design and process. }\end{array}$ \\
\hline $\begin{array}{l}\text { Advisers to } \\
\text { constitution makers }\end{array}$ & $\begin{array}{l}\text { Utilize International IDEA's knowledge and networks to offer high-quality advice to } \\
\text { constitution makers, civil society and constitution implementers. Expand coordination } \\
\text { and collaboration in a coherent and communicative community of practice to advance } \\
\text { good practices in constitution-building processes. }\end{array}$ \\
\hline Civil society & $\begin{array}{l}\text { Hold constitution makers accountable, inform the public about constitution-building } \\
\text { processes, and promote public participation in the process. }\end{array}$ \\
\hline $\begin{array}{l}\text { Constitutional } \\
\text { implementers }\end{array}$ & $\begin{array}{l}\text { Interpret and operationalize constitutional provisions following ratification in a manner } \\
\text { that respects fundamental democratic principles and human rights. Promote respect for } \\
\text { the rule of law and constitutionalism under agreed constitutional frameworks. }\end{array}$ \\
\hline
\end{tabular}

POLITICAL PARTICIPATION

AND REPRESENTATION

Boundary partner

\section{Outcome objective}

National and subnational Improve their legislative, oversight and representation functions, and institutional parliaments systerns to become more transparent, inclusive, responsive and accountable to citizens.

Political parties and movements

Improve their functions (mobilizing citizens, aggregating their interests into political programmes, recruiting political leaders to contest elections, and organizing governments and parliaments) so they contribute to a party system that is inclusive, responsive and accountable to all citizens.

Public interest groups

Engage with representative institutions in a democratic and effective way to improve public policy and practice, and to hold political decision-makers to account.

Oversight agencies

Monitor, prevent and mitigate threats to democracy, and threats posed by both illegal and illicit money in politics.

National and subnational governments
Improve their practices and decision-making processes to become more transparent, inclusive, responsive and accountable to all citizens

\section{Impact}

To clarify what a project aims to contribute at an over arching level, International IDEA has defined a set of impac bjectives and impact indicators. Impact objectives are high-level societal changes outside the sphere of direct influence of our activities within our three impact areas: electoral processes, constitution-building processes, and political participation and representation. The impact indicators consist of a mix of attributes, subattributes and indicators from International IDEA's Global State of Democracy indices. Table 2 lists the impact objectives and impact indicators for each of the three impact areas.

In International IDEA's system for learning-based management, analyses of impact indicators influence the annua planning process, where we make strategic choices regarding where and with whom we shall undertake our activities. The outcome of this process is documented in each year's Programme and Budget, which is presented to the Council of Member States annually.

\section{(3) bridge}

IDA

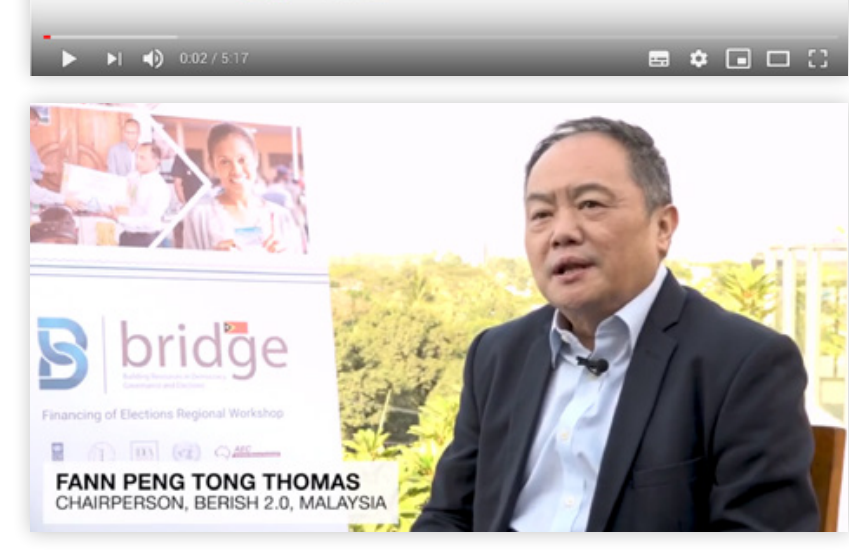

Timor Leste hosts regional BRIDGE workshop on financing elections. BRIDGE, a modular professional development program focused on elections, is designed to improve skills, knowledge and confidence through active-learning methodology on general principles of sound financial planning. BRIDGE has been conducted in more than 100 countries, for over 15,000 participants.

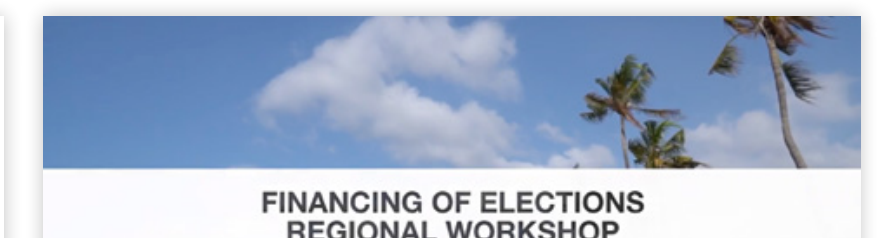

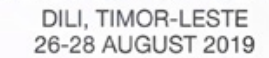

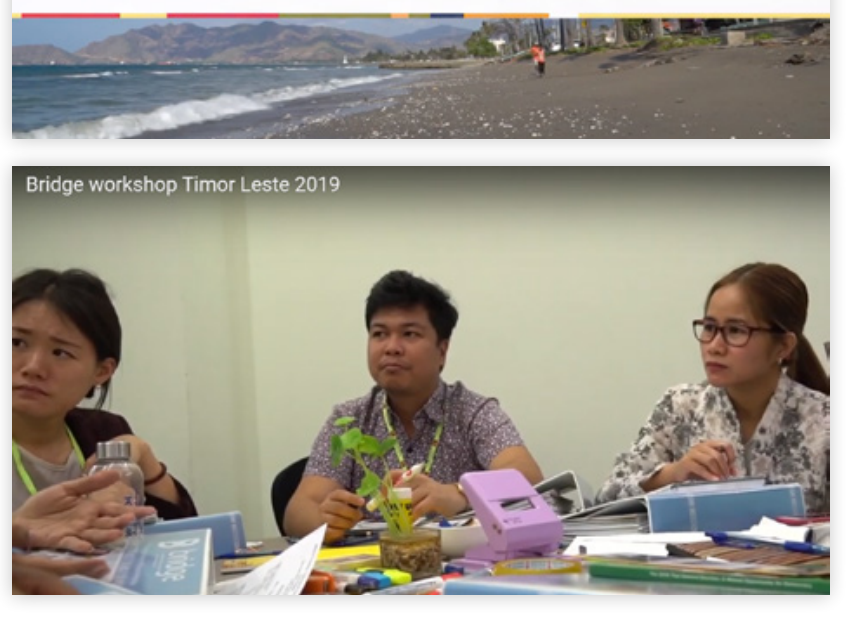
nt 
Table 2: International IDEA's impact objectives and impact indicators

\begin{tabular}{|c|c|c|c|}
\hline & Impact objectives & \multicolumn{2}{|c|}{ Impact indicators } \\
\hline \multirow{3}{*}{$\begin{array}{l}\text { ELECTORAL } \\
\text { PROCESSES }\end{array}$} & \multirow{3}{*}{ Credible and well-run electoral processes. } & 1.1 & Clean elections \\
\hline & & 1.2 & Inclusive suffrage \\
\hline & & 3.1.30 & Election and other electoral violence \\
\hline \multirow{5}{*}{$\begin{array}{l}\text { CONSTITUTION- } \\
\text { BUILDING } \\
\text { PROCESSES }\end{array}$} & $\begin{array}{l}\text { An inclusive constitution-building process } \\
\text { informed by international knowledge and } \\
\text { experiences on constitutional design and } \\
\text { process. }\end{array}$ & & $\begin{array}{l}\text { There are no suitable impact } \\
\text { indicators for constitution-building } \\
\text { processes. Progress needs to be } \\
\text { tracked with qualitative methods. }\end{array}$ \\
\hline & \multirow{3}{*}{$\begin{array}{l}\text { The constitution is implemented under } \\
\text { agreed constitutional frameworks and } \\
\text { contributes to reduced tensions and } \\
\text { conflicts. }\end{array}$} & 2.2.23 & Internal conflict \\
\hline & & 2.3.6 & Religious tensions \\
\hline & & 2.3.7 & Ethnic tensions \\
\hline & & 4.2 & Predictable enforcement \\
\hline \multirow{11}{*}{$\begin{array}{l}\text { POLITICAL } \\
\text { PARTICIPATION AND } \\
\text { REPRESENTATION }\end{array}$} & \multirow{2}{*}{$\begin{array}{l}\text { Public administration is inclusive, impartial } \\
\text { and rigorous. }\end{array}$} & 3.8.7 & $\begin{array}{l}\text { Rigorous and impartial public } \\
\text { administration }\end{array}$ \\
\hline & & 4.2 & Predictable enforcement \\
\hline & \multirow{4}{*}{$\begin{array}{l}\text { Civil society engage freely with representative } \\
\text { institutions in a democratic and effective } \\
\text { way. }\end{array}$} & 2.2.10 & $\begin{array}{l}\text { Freedom of association and } \\
\text { assembly }\end{array}$ \\
\hline & & 3.6.6 & Engaged society \\
\hline & & 3.10 .3 & CSO repression \\
\hline & & 5.1 & Civil society participation \\
\hline & \multirow{2}{*}{$\begin{array}{l}\text { The parliament exercises effective control } \\
\text { of the executive power and represents the } \\
\text { interests of all citizens. }\end{array}$} & 3.1 & Effective parliament \\
\hline & & 1. & Representative government \\
\hline & $\begin{array}{l}\text { Political parties and movements contribute } \\
\text { to a party system that is inclusive, responsive } \\
\text { and accountable to all citizens. }\end{array}$ & & $\begin{array}{l}\text { There are no suitable impact } \\
\text { indicators for this impact objective. } \\
\text { Progress needs to be tracked with } \\
\text { qualitative methods. }\end{array}$ \\
\hline & \multirow{2}{*}{$\begin{array}{l}\text { Oversight agencies monitor, prevent and } \\
\text { mitigate threats posed by both illegal and } \\
\text { illicit money in politics. }\end{array}$} & 3.1.3 & Disclosure of campaign donations \\
\hline & & 3.1.4 & Public campaign financing \\
\hline
\end{tabular}
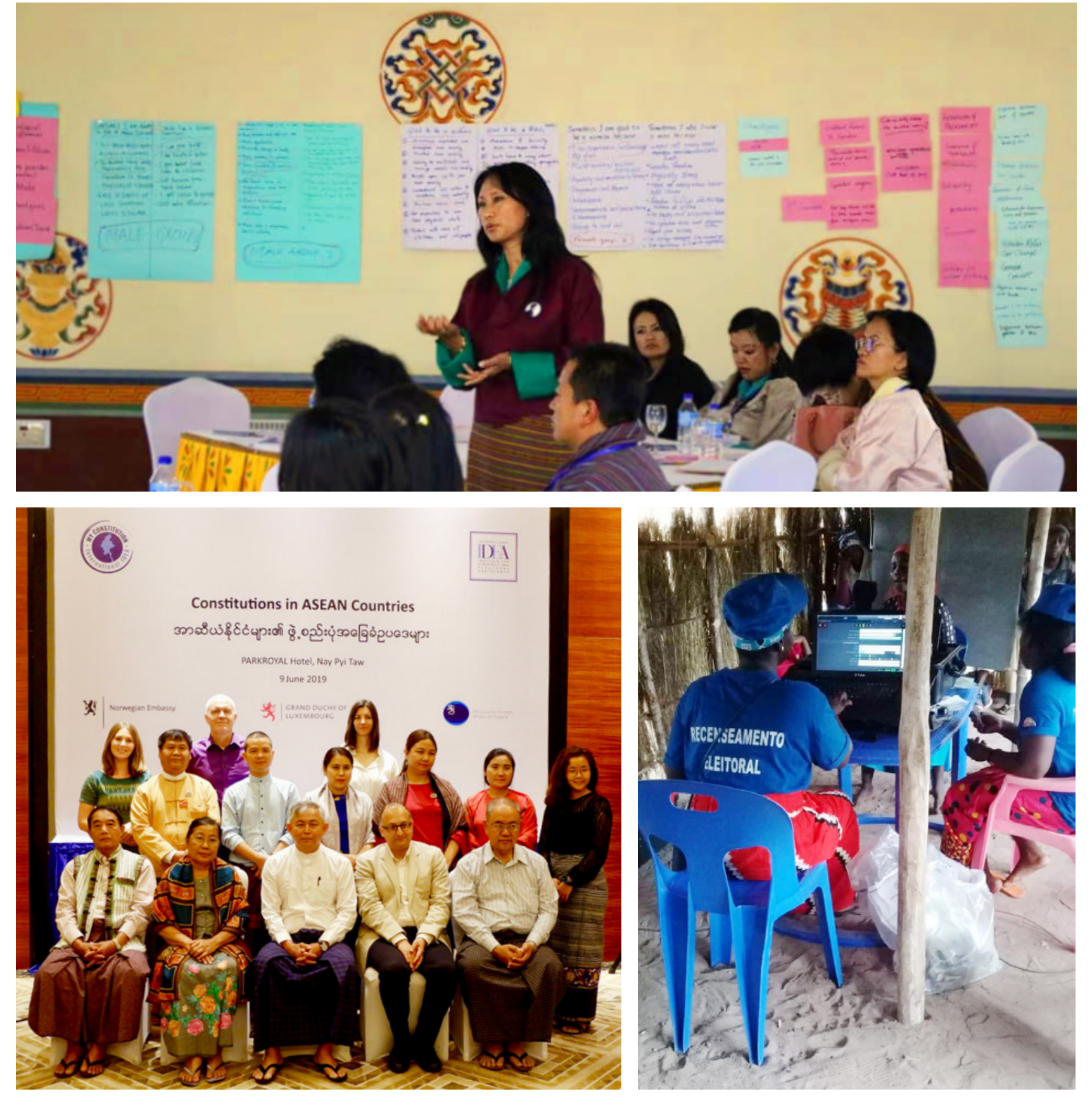

Top: Former leader of Druk Chirwang Tshogpa (DCT), Lily Wangchuk, speaks at the Bhutan Women Parliamentary Caucus orientation workshop held in Paro in November 2019.

Left: International IDEA's MyConstitution programme provided trainings about constituitions in Association of Southeast Asian Nations countries in 2019.

Right: The EU-funded 'Support to Consolidation of Democracy in Mozambique Programme' worked with citizen voter registration officials. 


\title{
DEMOCRACY IN ACTION
}

\author{
Annual Outcome Report 2019
}

The International Institute for Democracy and Electoral Assistance (International IDEA) is an intergovernmental organization with the mandate to promote and advance democracy worldwide.

International IDEA contributes to the public debate on democracy and assists in strengthening processes, reforms, institutions and actors that build, advance and safeguard democracy, with a focus on electoral processes, constitution-building processes, and political participation and representation. Mainstreamed across all our work are gender and inclusion, conflict sensitivity and sustainable development.

International IDEA is governed by a council composed of its Member States and assisted by a Board of Advisers.

International IDEA's Member States are democracies and provide both political and financial support to the work of the organization. They are Australia, Barbados, Belgium, Benin, Botswana, Brazil, Cabo Verde, Canada, Chile, Costa Rica, Dominican Republic, Finland, Germany, Ghana, India, Indonesia, Luxembourg, Mauritius, Mexico, Mongolia, Namibia, the Netherlands, Norway, Panama, Peru, the Philippines, Portugal, South Africa, Spain, Sweden, Switzerland, Tunisia and Uruguay. Japan has observer status.

\section{International IDEA}

SE-103 34 Stockholm

SWEDEN

+4686983700

info@idea.int

www.idea.int 